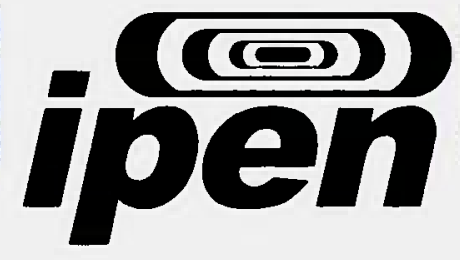

AUTARQUIA ASSOCIADA À UNIVERSIDADE DE SÃO PAULO

USO DE SUBSTÂNCIAS ANTIOXIDANTES NA RESPOSTA A RADIAÇÃO DOS HIDROCOLÓIDES CARRAGENANAS, AGARANAS E ALGINATOS UTILIZADOS NA INDÚSTRIA ALIMENTÍCIA

ANTONIO JOÃO ALISTE

Tese apresentada como parte dos requisitos para obtenção do Grau de Doutor em Ciências na Área de Tecnologia Nuclear - Aplicações.

Orientadora:

Dra. Nélida Lúcia del Mastro

São Paulo 
INSTITUTO DE PESQUISAS ENERGÉTICAS E NUCLEARES Autarquia associada à Universidade de São Paulo

USO DE SUBSTÂNCIAS ANTIOXIDANTES NA RESPOSTA À RADIAÇÃO DOS HIDROCOLÓIDES CARRAGENANAS, AGARANAS E ALGINATOS UTILIZADOS NA INDÚSTRIA

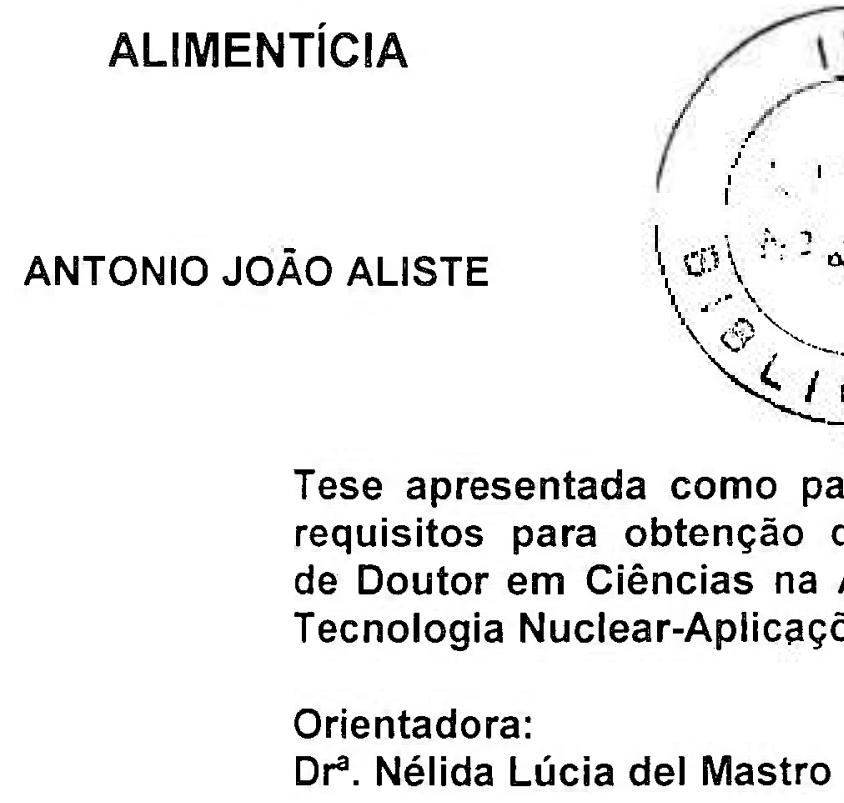

Dra. Nélida Lúcia del Mastro

SÃO PAULO

2006 
"A verdadeira educação não desconhece o valor dos conhecimentos cientificos ou aquisições literárias: mas acima da instrução aprecia a capacidade, acima da capacidade a bondade, e acima das aquisições intelectuais o caráter."

Ellen G. White 


\section{AGRADECIMENTOS}

A todos os meus amigos e colegas do IPEN, que tornaram possivel esse trabalho. Desculpe meus amigos se muitas vezes não fui merecedor da sua amizade, mas saibam que sempre serão lembrados.

Ao Centro Tecnológico das Radiações - CTR/IPEN-CNEN, na pessoa do Dr. Wilson Calvo, enfatizando-se śua constante disposição em auxiliar e facilitar o trabalho de todos os alunos de pós-graduação.

Não vou citar nomes para não esquecer alguém, mas agradeço também a todos os funcionários do CTR e do IPEN que possibilitaram de alguma forma a realização desse trabalho.

À minha orientadora Dra. Nélida, que muito me incentivou para que pudesse chegar ao término da confecção da tese com sucesso.

Ao CNPq pela bolsa de Doutorado.

A minha familia pela compreensão e apoio, em todos os momentos.

E principalmente a Deus que me possibilitou estar aqui nesse momento. 


\section{SUMÁRIO}

Página

RESUMO

ABSTRACT

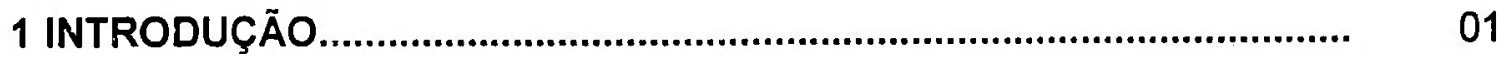

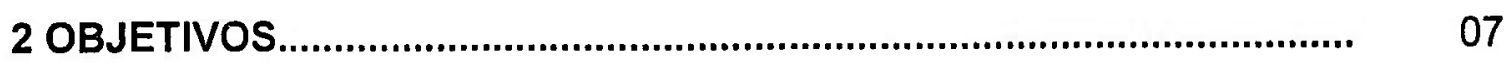

3 REVISÃO DA LITERATURA.......................................................... 07

3.1 Polissacarideos alimentares................................................ 07

3.1.1 Agaranas......................................................................... 10

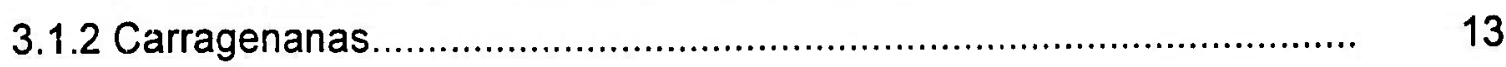

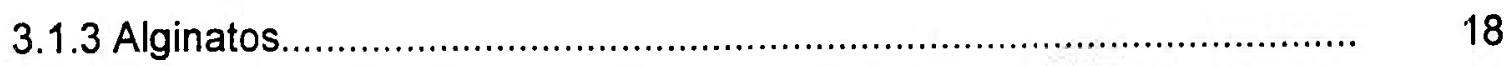

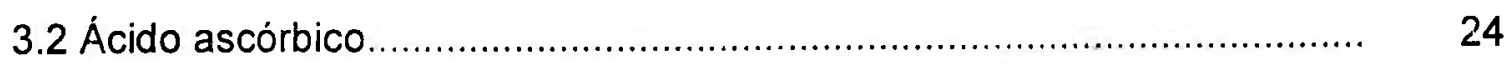

3.3 Rosela (Hibiscus sabdariffa L.).................................................... 25

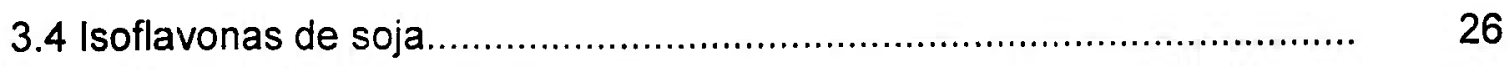

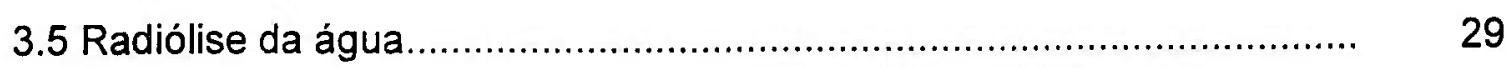

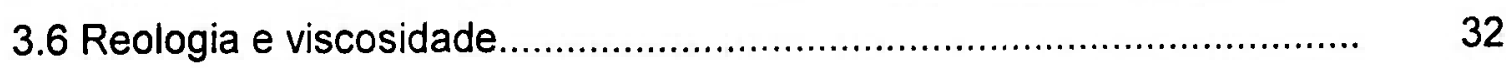

3.7 Legislação de alimentos irradiados.............................................. 37

4 MATERIAL E MÉTODOS............................................................. 38

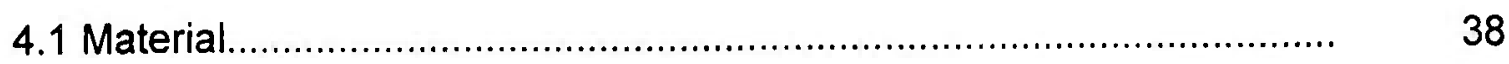

4.1.1 Agarana, Carragenana e Alginato de sódio................................. 38

4.1.2 Ácido ascórbico .............................................................. 38

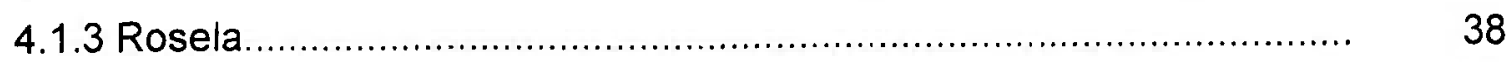

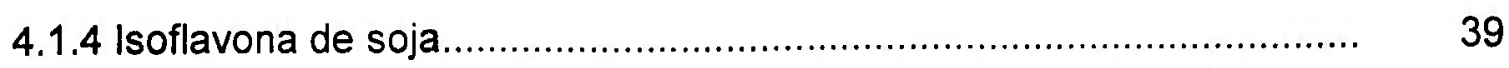




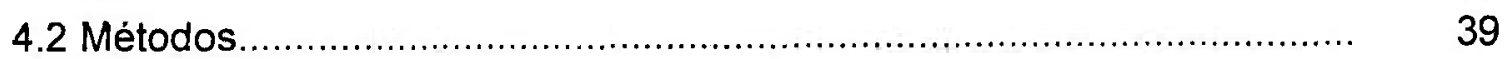

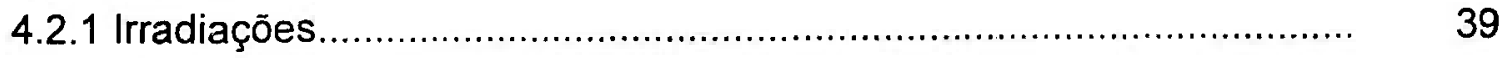

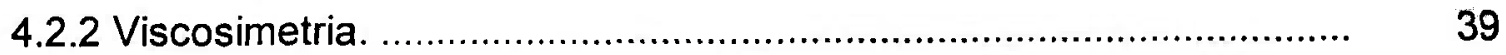

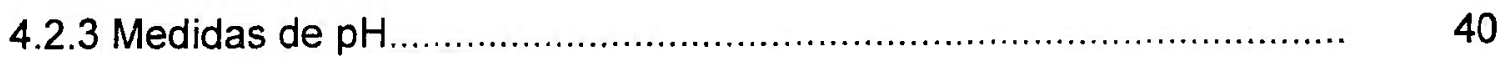

4.2.4 Análise estatistica............................................................ 40

5 RESULTADOS ........................................................................ 41

5.1 Agarana, carragenana e alginato de sódio..................................... 41

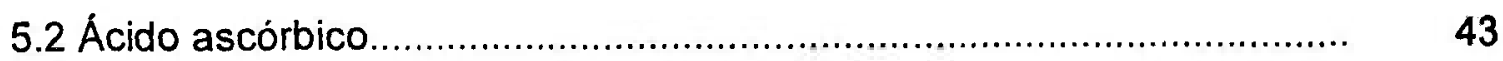

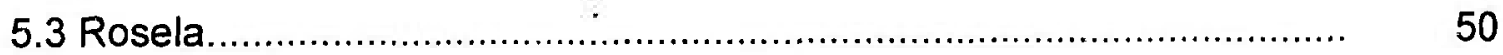

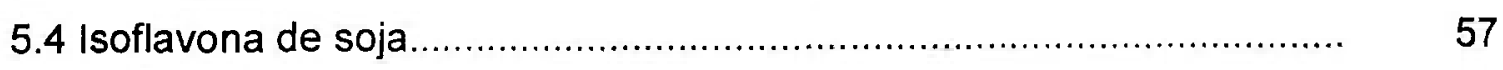

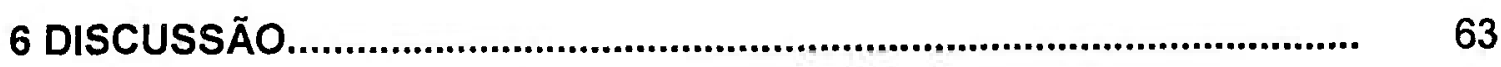

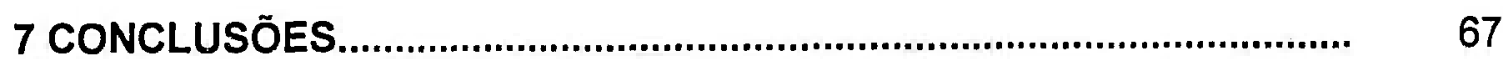

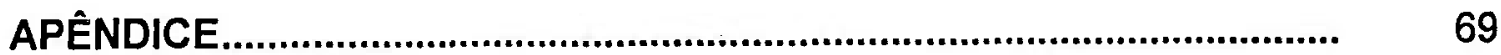

REFERÊNCIAS BIBLIOGRÁFICAS................................................. 79 


\section{LISTA DE FIGURAS}

Figura

Página

01 Fórmulas estruturais da agarose (I) e agaropectina (II)

02 Fórmula estrutural da k-carragenana

03 Fórmula estrutural da l-carragenana

04 Fórmula estrutural da $i_{\diamond}$-carragenana

05 Fórmula estrutural do ácido manurônico

06 Fórmula estrutural do ácido gulurônico 20

07 Segmento de polimeros no ácido algínico constituído 20 essencialmente de unidades de ácido $\delta$-manurônico (-M-M-M-M-M-)

08 Segmento de polímeros no ácido algínico constituido essencialmente de unidades de ácido $\lambda$-gulurônico (-G-G-G-G-G-)

09 Segmento de polímeros no ácido algínico constituído de unidades alternadas de residuos de ácido $\lambda$-gulurônico e $\delta$-manurônico (-M-GM-G-M-)

10 Fórmula estrutural do ácido L-ascórbico

11 Fórmula estrutural da genisteina

12 Fórmula estrutural da daidzeína $\quad 27$

13 Viscosidade em função da dose, das soluções de agarana, carragenana e alginato de sódio, a taxa de cisalhamento de $330 \mathrm{~s}^{-1}$ e $60^{\circ} \mathrm{C}$.

14 Viscosidade em funçāo da taxa de cisalhamento das soluções de agarana, carragenana e alginato de sódio, a $0 \mathrm{kGy}$ e $60^{\circ} \mathrm{C}$. 
15a Viscosidade em função da dose, das soluções de agarana na presença de diferentes concentrações de ácido ascórbico, a taxa de cisalhamento de $330 \mathrm{~s}^{-1}$ e $60^{\circ} \mathrm{C}$.

15b Viscosidade em função da dose, das soluções de agarana na presença de diferentes concentrações de ácido ascórbico, a taxa de cisalhamento de $330 \mathrm{~s}^{-1}$ e $60^{\circ} \mathrm{C}$ (dados normalizados).

16a Viscosidade em função da dose, das soluções de carragenana na presença de diferentes concentrações de ácido ascórbico, a taxa de cisalhamento de $330 \mathrm{~s}^{-1} \cdot \mathrm{e} 60^{\circ} \mathrm{C}$.

16b Viscosidade em função da dose, das soluções de carragenana na presença de diferentes concentrações de ácido ascórbico, a taxa de cisalhamento de $330 \mathrm{~s}^{-1}$ e $60^{\circ} \mathrm{C}$ (dados normalizados).

17a Viscosidade em função da dose, das soluções de alginato de sódio na presença de diferentes concentrações de ácido ascórbico a taxa de cisalhamento de $330 \mathrm{~s}^{-1}$ e $45^{\circ} \mathrm{C}$.

17b Viscosidade em função da dose, das soluções de alginato de sódio na presença de diferentes concentrações de ácido ascórbico a taxa de cisalhamento de $330 \mathrm{~s}^{-1}$ e $45^{\circ} \mathrm{C}$ (dados normalizados).

18a Viscosidade em função da dose, das soluções de agarana, na presença de diferentes soluções de extrato de rosela, a taxa de cisalhamento de $330 \mathrm{~s}^{-1}$ e $60^{\circ} \mathrm{C}$.

18b Viscosidade em função da dose, das soluçōes de agarana, na presença de diferentes soluções de extrato de rosela, a taxa de cisalhamento de $330 \mathrm{~s}^{-1}$ e $60^{\circ} \mathrm{C}$ (dados normalizados).

19a Viscosidade em função da dose, das soluções de carragenana na presença de diferentes concentrações de extrato de rosela, a taxa de cisalhamento de $330 \mathrm{~s}^{-1}$ e $60^{\circ} \mathrm{C}$.

19b Viscosidade em função da dose, das soluções de carragenana na presença de diferentes concentrações de extrato de rosela, a taxa de cisalhamento de $330 \mathrm{~s}^{-1}$ e $60^{\circ} \mathrm{C}$ (dados normalizados). 
20a Viscosidade em função da dose, das soluções de alginato de sódio na presença de diferentes concentrações de extrato de rosela, a taxa de cisalhamento de $330 \mathrm{~s}^{-1}$ e $45^{\circ} \mathrm{C}$.

20b Viscosidade em função da dose, das soluções de alginato de sódio na presença de diferentes concentrações de extrato de rosela, a taxa de cisalhamento de $330 \mathrm{~s}^{-1}$ e $45^{\circ} \mathrm{C}$ (dados normalizados).

21a Viscosidade em função da dose, das soluções de agarana na presença de diferentes concentrações de isoflavona de soja, a taxa de cisalhamento de $330 \mathrm{~s}^{-1}$ e $60^{\circ} \mathrm{C}$.

21b Viscosidade em função da dose, das soluções de agarana na presença de diferentes concentrações de isoflavona de soja, a taxa de cisalhamento de $330 \mathrm{~s}^{-1}$ e $60^{\circ} \mathrm{C}$ (dados normalizados).

22a Viscosidade em função da dose, das soluções de carragenana na presença de diferentes concentrações de isoflavona de soja, a taxa de cisalhamento de $330 \mathrm{~s}^{-1}$ e $60^{\circ} \mathrm{C}$.

22b Viscosidade em função da dose, das soluções de carragenana na presença de diferentes concentrações de isoflavona de soja, a taxa de cisalhamento de $330 \mathrm{~s}^{-1}$ e $60^{\circ} \mathrm{C}$ (dados normalizados).

23a Viscosidade em função da dose, das soluções de alginato de sódio na presença de diferentes concentrações de isoflavona de soja, a taxa de cisalhamento de $330 \mathrm{~s}^{-1}$ e $45^{\circ} \mathrm{C}$.

23b Viscosidade em função da dose, das soluções de alginato de sódio na presença de diferentes concentrações de isoflavona de soja, a taxa de cisalhamento de $330 \mathrm{~s}^{-1}$ e $45^{\circ} \mathrm{C}$ (dados normalizados). 


\section{LISTA DE TABELAS}

Tabela

Página

01 Faixas de doses de radiação ionizante necessárias para os diversos tratamentos de alimentos

02 Gomas e espessantes comumente usados em alimentos

03 Medidas do pH das soluções de agarana em função da dose e da concentração de ácido ascórbico.

04 Medidas do $\mathrm{pH}$ das soluções de carragenana em função da dose e da concentração de ácido ascórbico

05 Medidas do pH das soluções de alginato de sódio em função da dose e da concentração de ácido ascórbico.

06 Comparação da significância estatística $(P)$ das soluções de agarana, carragenana e alginato de sódio entre irradiado e não irradiado (método $t$ de Student).

07 Medidas do $\mathrm{pH}$ das soluções de agarana em função da dose e da concentração de rosela.

08 Medidas do $\mathrm{pH}$ das soluções de carragenana em função da dose e da concentração de extrato de rosela.

09 Medidas do $\mathrm{pH}$ de soluções de alginato de sódio em função da dose e da concentração de rosela.

10 Comparação da significância estatística $(P)$ das soluções de agarana, carragenana e alginato de sódio entre irradiado e não irradiado (método t de Student)

11 Medidas do $\mathrm{pH}$ das soluções de agarana em função da dose e da concentração de isoflavona de soja. 
12 Medidas do $\mathrm{pH}$ das soluções de carragenana em função da dose e da concentração de isoflavona de soja.

13 Medidas do $\mathrm{pH}$ das soluções de alginato de sódio em função da dose e da concentração isoflavona de soja.

14 Comparação da significância estatística $(P)$ das soluções de agarana, carragenana e alginato de sódio entre irradiado e não irradiado (método t de Student).

15 Viscosidade em função da dose, das soluções de agarana, carragenana e alginato de sódio, a taxa de cisalhamento de 330 $\mathrm{s}^{-1}$ e $60^{\circ} \mathrm{C}$.

16 Viscosidade em função da dose, das soluções de agarana na presença de diferentes concentrações de ácido ascórbico, a taxa de cisalhamento de $330 \mathrm{~s}^{-1}$ e $60^{\circ} \mathrm{C}$, dados obtidos do viscosímetro e normalizados.

17 Viscosidade em função da dose, das soluçōes de carragenana na presença de diferentes concentrações de ácido ascórbico, a taxa de cisalhamento de $330 \mathrm{~s}-1$ e $60^{\circ} \mathrm{C}$ dados obtidos do viscosimetro e normalizados.

18 Viscosidade em função da dose, das soluções de alginato de sódio na presença de diferentes concentrações de ácido ascórbico, a taxa de cisalhamento de $330 \mathrm{~s}^{-1}$ e $45^{\circ} \mathrm{C}$ dados obtidos do viscosímetro e normalizados.

19 Viscosidade em função da dose, das soluções de agarana, na presença de diferentes concentrações de extrato de rosela, a taxa de cisalhamento de $330 \mathrm{~s}^{-1}$ e $60^{\circ} \mathrm{C}$ dados obtidos do viscosímetro e normalizados.

20 Viscosidade em função da dose, das soluções de carragenana na presença de diferentes concentrações de extrato de rosela, a taxa de cisalhamento de $330 \mathrm{~s}^{-1}$ e $60^{\circ} \mathrm{C}$ dados obtidos do viscosimetro e normalizados. 
21 Viscosidade em função da dose, das soluções de alginato de sódio na presença de diferentes concentrações de extrato de rosela, a taxa de cisalhamento de $330 \mathrm{~s}^{-1}$ e $45^{\circ} \mathrm{C}$, dados obtidos do viscosímetro e normalizados.

22 Viscosidade em função da dose, das soluções de agarana na presença de diferentes concentrações de isoflavona de soja, a taxa de cisalhamento de $330 \mathrm{~s}^{-1}$ e $60^{\circ} \mathrm{C}$ dados obtidos do viscosimetro e normalizados.

23 Viscosidade em função da dose, das soluções de carragenana na presença de diferentes concentrações de isoflavona de soja, a taxa de cisalhamento de $330 \mathrm{~s}^{-1}$ e $60^{\circ} \mathrm{C}$ dados obtidos do viscosimetro e normalizados.

24 Viscosidade em função da dose, das soluções de alginato de sódio na presença de diferentes concentrações de isoflavona de soja, taxa de cisalhamento de $330 \mathrm{~s}^{-1}$ e $45^{\circ} \mathrm{C}$, dados obtidos do viscosimetro e normalizados. 


\title{
USO DE SUBSTÂNCIAS ANTIOXIDANTES NA RESPOSTA À RADIAÇÃO DOS HIDROCOLÓIDES CARRAGENANAS, AGARANAS E ALGINATOS UTILIZADOS NA INDÚSTRIA ALIMENTÍCIA
}

\author{
Antônio João Aliste
}

\section{RESUMO}

Carragenanas, agaranas e alginatos são hidrocolóides largamente utilizados em todo tipo de produtos alimentícios como aditivos espessantes. Eles não são absorvidos pelo organismo e, portanto não introduzem calorias extras na dieta. A irradiação se apresenta com grande potencial como um método alternativo na preservação de alimentos pois não induz aumento da temperatura, e é, portanto, de grande eficácia na descontaminação de ingredientes alimentícios sensiveis ao calor. Neste trabalho, soluções dos hidrocolóides agararana, carragenana e aiginato de sódio, foram irradiadas com diferentes doses (0-10 kGy) de radiação gama de Co-60 na presença de antioxidantes também utilizados na indústria alimenticia: ácido ascórbico, extrato vegetal de rosela (Hibiscus sabdariffa L.) e isoflavona de soja. As soluções dos polissacarídeos comestiveis agarana, carragenana e alginato de sódio mostraram ser bons sistemas para avaliar o efeito da radiação ionizante por apresentarem radiossensibilidade caracteristica medida pelas mudanças na viscosidade. Os resultados obtidos mostram que esses antioxidantes apresentam, no geral, ação radioprotetora o que pode ser de grande valia nas aplicações futuras da irradiação de alimentos em escala comercial. 


\title{
USE OF ANTIOXIDANTS SUBSTANCES TO PROTECT THE HIDROCOLLOIDS CARRAGEENAN, AGARAN AND ALGINATES USED IN FOOD INDÚSTRY WHEN EXPOSE TO RADIATION
}

\author{
Antonio João Aliste
}

\begin{abstract}
Carrageenan, agaran e alginates are hydrocolloids largely employed in every kind of food products as stabilizing agent and viscosity builder. The human body does not absorb them, so they do not introduce extra calories in the diet. Irradiation is presented as an important alternative method in food preservation because do not induce temperature increase being of good efficiency in cold food ingredients decontamination. In this work aqueous solutions of carrageenan, agar e sodium alginate were gamma irradiated (0-10 kGy) in presence of ascorbic acid, roselle (Hibiscus sabdariffa L.) extract and soy isoflavone. Edible polysaccharide solutions showed to be suitable systems for the evaluation of ionizing radiation effects as they presented a singular radiosensitivity through viscosity changes. The results obtained showed that in general the antioxidants employed had a radioprotective action that can be of importance in the future commercial applications of food irradiation.
\end{abstract}




\section{INTRODUÇÃO}

A incidência de moléstias causadas por alimentos tem crescido dramaticamente desde 1945 e hoje é um dos mais comuns problemas de saúde no mundo. Por outro lado, problemas de estocagem e processamento tornam necessária a procura por métodos alternativos efetivos de preservação de alimentos.

Na opinião da Organização Mundial da Saúde (WHO), a irradiação de alimentos é uma tecnologia que pode ser utilizada com segurança no controle dos mais sérios problemas relacionados com os alimentos: as perdas provenientes da deterioração e as doenças que podem ser ocasionadas pelo consumo de alimentos contaminados por microorganismos patogênicos (KAMAT, 2005). Por outro lado, pela sua capacidade de eliminar insetos e outras pragas, a irradiação oferece uma importante alternativa ao uso de produtos químicos como meio de atender os requisitos quarentenários para a desinfestação de produtos para o comércio internacional (WHO, 1989).

Em 1981, um comitê conjunto de especialistas em Salubridade de Alimentos Irradiados da Organização das Nações Unidas para a Agricultura e Alimentação (FAO), da Agência Internacional de Energia Atômica (IAEA) e da WHO concluiu que a irradiação de qualquer produto alimentício com dose média total de até $10 \mathrm{kGy}$ não oferecia qualquer risco toxicológico ou problema de ordem microbiológica ou nutricional. Entretanto, num relatório de especialistas convocados pelas FAO/IAEANHO para estudar o efeito de altas doses de irradiação, concluiu-se que alimentos irradiados com doses acima de $10 \mathrm{kGy}$ não causam nenhum risco de saúde para os consumidores (FOOD AND AGRICULTURE ORGANIZATION; INTERNATIONAL ATOMIC ENERGY AGENCY; WORLD HEALTH ORGANIZATION, 1999).

O Grupo Consultivo Internacional sobre Irradiação de Alimentos (ICGFI), foi criado em 1984, para estudar o tema e registrar os avanços, 
benefícios e a segurança dos alimentos tratados por irradiação ionizante. Foi um grupo de estudo conjunto, da Organização das Nações Unidas para Agricultura e Alimentos (FAO), da Organização Mundial de Saúde (WHO), e da Agência Internacional de Energia Atômica (IAEA), encerrado em 2004. De 1993 até 2001, uma pesquisadora do IPEN, foi a representante brasileira nomeada junto ao ICGFI. Dentre as tarefas do ICGFI, um órgão multi governamental que contou com 46 paises membros, encontrava-se a função de proporcionar informações sobre a utilização segura e apropriada da tecnologia de irradiação aos paises membros (INTERNATIONAL CONSULTATIVE GROUP ON FOOD IRRADIATION, 1990).

Mais de 40 paises possuem legislação autorizando o uso da radiação em alimentos. São eles: África do Sul, Alemanha, Argentina, Bangladesh, Bélgica, Brasil, Canadá, Chile, China, Costa Rica, Coréia, Croácia, Cuba, Dinamarca, Espanha, EUA, Filipinas, Finlândia, França, Holanda, Hungria, Índia, Indonésia, Irã, Israel, Itália, República Tcheca, Japão, México, Noruega, Paquistão, Polônia, Reino Unido, Federação Russa, Síria, Tailândia, República Tcheca, Ucrânia, Uruguai e Vietnã (DEL MASTRO, 1999).

O tratamento por irradiação é uma das alternativas de conservação de alimentos, já que não afeta de maneira adversa a qualidade do alimento. A possibilidade do uso da irradiação, para prolongar o tempo de vida de certos alimentos, tornou-se uma proposta a partir dos anos 50 , quando se mostrou que a irradiação poderia ser aplicada para matar bactérias e retardar a germinação e amadurecimento de frutas e vegetais em grande escala e começaram a ser desenvolvidas instalações industriais de irradiação (BAZAFKAN, 1996).

A radiação só pode acentuar as qualidades do alimento, e este já estiver deteriorado, não poderá ser melhorado com esse processo.

Um dos grandes problemas com relação à irradiação de alimentos é a falta de informação da população com relação a esse método de preservação. $O$ WHO teme que a atuação de grupos que se opõem ao processo seja essencialmente baseada em influências emocionais ou ideológicas e pode 
impedir o seu uso em vários países que só teriam a ganhar com sua aplicação (BAZAFKAN, 1996).

Na merenda escolar nos EUA em 2004, a carne oferecida foi irradiada. A irradiação de alimentos foi utilizada porque a radiação de alta energia mata microorganismos patogênicos que possam estar sendo veiculados na carne e no frango, por exemplo. Em frutas e vegetais, especiarias e trigo e farinhas a radiação ionizante pode ser utilizada para controlar esporos e a infestação por insetos ou outras pragas. Com a irradiação de carne, no minimo $99,99 \%$ da Escherichia coli e outras bactérias nocivas são eliminadas, tornando o produto seguro para consumo. $O$ governo americano estima que ocorram aproximadamente 73000 casos de infecção por E. coli a cada ano e desses 61 mortes, várias delas de crianças. Um grande número das enfermidades transmitidas por alimentos está associado ao consumo de carne contaminada (OSTERHOLM, 2004).

Os argumentos contra a irradiação de alimentos hoje, são similares aqueles usados décadas atrás contra a pasteurização. Os oponentes da pasteurização diziam que ela não evitaria doenças, causaria problemas no sabor e seria uma desculpa para que os fazendeiros não observassem as boas práticas de produção. Isso mostrou não ser verdade e a pasteurização do leite contribui há mais de 50 anos para a saúde das crianças. Da mesma forma que é inconcebivel consumir leite não pasteurizado, pelos riscos conhecidos, deve se pensar na irradiação da carne como uma forma de diminuir os riscos de contaminação. Porém, deve-se ter em mente que a irradiação não é um substituto para as boas práticas higiênicas de produção e consumo (OSTERHOLM, 2004).

Aproximadamente meio milhão de toneladas de produtos $e$ ingredientes alimentícios são irradiados anualmente no mundo, o que ainda representa um volume insignificante no contexto mundial (INTERNATIONAL CONSULTATIVE GROUP ON FOOD IRRADIATION, 1992).

As radiações aplicadas aos alimentos denominam-se "radiações ionizantes", porque sua energia é suficientemente alta para desalojar os elétrons 
dos átomos e moléculas, e para convertê-los em partículas carregadas eletricamente, que se denominam ions. Os raios gama $e$ os raios $X$ são semelhantes às ondas de rádio, às microondas, aos raios ultravioletas e aos raios de luz visivel diferindo apenas no valor de sua energia. Os raios $X$ com energias variáveis são produzidos por instrumentos. Os raios gama de energia específica provêm da desintegração espontânea de radionuclideos (INTERNATIONAL CONSULTATIVE GROUP ON FOOD IRRADIATION, 1990).

$\mathrm{Na}$ irradiação de alimentos só se utilizam determinadas fontes de radiação, a saber: os radionuclideos Cobalto-60 ( $t_{/ 2} 5,263$ anos; $\beta-0,314 \mathrm{MeV} ; \gamma$ $1,173,1,332 \mathrm{MeV}$ ) ou Césio-137 ( $t_{/ / 2} 30$ anos; $\beta^{-} 0,514,1,176 \mathrm{MeV}$ que decai e atinge equilíbrio com o ${ }^{137 \mathrm{~m}} \mathrm{Ba}, t_{/ / 2} 2,554 \mathrm{~min}, \gamma 0,662 \mathrm{MeV}$ ) aparelhos de raios $X$ com uma energia máxima de $5 \mathrm{MeV}$ e feixes de elétrons com uma energia máxima de $10 \mathrm{MeV}$. As energias dessas fontes de radiação são muito baixas para induzir radioatividade em quaisquer materiais, incluindo alimentos. Dos radionuclídeos, o Césio-137 praticamente não é mais utilizado, pelo fato de sua pouca disponibilidade (INTERNATIONAL CONSULTATIVE GROUP ON FOOD IRRADIATION, 1990). A irradiação não aquece o material tratado, o alimento mantém seu frescor (peixe, frutas, vegetais) e seu estado físico (congelado ou mercadorias secas). Os alimentos podem ser irradiados mesmo embalados e os agentes que causam estragos (bactérias, insetos, etc.) são inativados com esse processo. (KOOIJ, 1981).

O beneficio da qualidade higiênica de alimentos irradiados pode ser tão significante quanto, ou até maior que as vantagens econômicas. Isto porque doses de aproximadamente $5 \mathrm{kGy}$, podem inativar microorganismos patogênicos (por exemplo, Salmonella, Vibrião parahaemolyticus, Staphylococcus aureus, etc.), os quais são as principais causas das mais importantes doenças em alimentos in natura. A contaminação microbiana, por exemplo, esporos resistentes ao calor, em especiarias e misturas de temperos podem ser reduzidos por irradiação. Estes esporos causam problemas no enlatamento de derivados de carne, porque sua presença em especiarias exige, por exemplo, a aplicação de 
um tratamento pelo calor em carnes, o que resulta num produto final pouco aceitável sob o ponto de vista organoléptico (KOOIJ, 1981).

A fumigação com óxido de etileno, brometo de metila ou óxido de propileno era largamente utilizada para esterilizar ou reduzir a contaminação microbiana em especiarias. Comumente, a efetividade da fumigação depende da umidade que deve ser de no mínimo $10 \%$ para o sucesso do tratamento em especiarias. A fumigação não mata fungos, coloca em risco a saúde dos trabalhadores em fábricas de processamento de alimentos e leva à formação de cloridrinas, com possiveis efeitos tóxicos diretos. A irradiação é um processo, relativamente simples que pode ser aplicado no produto já embalado em substituição à fumigação (KOOIJ, 1981).

As perdas de produtos agrícolas durante a estocagem e distribuição podem ser tão altas quanto $50 \%$ a $70 \%$ em várias partes do mundo. A radiação gama tem provado ser um método eficiente também para desinfestação de peixes secos e defumados. Com doses de aproximadamente $2 \mathrm{kGy}$ consegue-se reduzir em $99 \%$ as larvas de moscas, porém doses tão baixas quanto $0,2 \mathrm{kGy}$, já são suficientes para inativá-las e não deixar que se desenvolvam para insetos adultos. Em certos casos a aplicação combinada de tratamentos é a melhor escolha. A adição de preservativos químicos, toxicologicamente permitidos como o sorbato e a irradiação podem estender consideravelmente a vida de prateleira de algumas mercadorias possibilitando desse modo sua larga distribuição (KOOIJ, 1981).

A dose a ser aplicada ao alimento depende do objetivo do tratamento. $\mathrm{Na}$ Tabela 1 estão listadas as faixas de doses adequadas para cada objetivo pretendido (LOAHARANU, 1994).

Durante as últimas décadas, uma crescente atenção foi dada ao papel dos radicais livres em oxidações biológicas. Para a proteção contra as ações danosas dos radicais livres é sugerido um aumento de antioxidantes na dieta alimentícia, especialmente aquelas ricas em gorduras polinsaturadas (DONNELLY \& ROBINSON, 1995). Os "scavengers" de radicais livres, ou seja, substancias capazes de neutralizá-los na forma ou através de antioxidantes 
adicionados são importantes para o sucesso da preservação dos alimentos. Sua adição a uma solução pode resultar na competição com o primeiro soluto pelos radicais livres. Quanto maior a capacidade do segundo soluto de se combinar com os radicais livres, menor 0 dano causado ao primeiro soluto e, portanto maior a sua eficiência como protetor (DONNELLY \& ROBINSON 1995; BLOCK, 1994).

Tabela 1 - Faixa de doses de radiação ionizante necessárias para os diversos tratamentos de alimentos (LOAHARANU, 1994).

\begin{tabular}{|c|c|c|}
\hline $\begin{array}{l}\text { Dose } \\
\text { (kGy) }\end{array}$ & Propósito & Tipo de Alimentos \\
\hline $25-70$ & $\begin{array}{l}\text { Esterilização: alimentos podem ser } \\
\text { estocados a temperatura ambiente }\end{array}$ & $\begin{array}{l}\text { Carne, frango, peixe, } \\
\text { produtos de padaria, } \\
\text { alguns vegetais, } \\
\text { alimentos prontos. }\end{array}$ \\
\hline $8-10$ & $\begin{array}{l}\text { Descontaminação: reduz o } n .^{\circ} \text { de } \\
\text { microorganismos, e repõem substâncias } \\
\text { químicas. }\end{array}$ & $\begin{array}{l}\text { Ingredientes secos, } \\
\text { tais como: pimenta, } \\
\text { ervas e temperos. }\end{array}$ \\
\hline $3-7$ & $\begin{array}{l}\text { Melhoria da segurança do alimento e } \\
\text { aumento da vida de prateleira: redução do } n^{\circ} \\
\text { de patógenos vegetativos e organismos } \\
\text { esporulados. Efeitos similares para a } \\
\text { pasteurização de liquidos }\end{array}$ & $\begin{array}{l}\text { Carne branca e } \\
\text { vermelha }\end{array}$ \\
\hline $1-3$ & $\begin{array}{l}\text { Extensão da vida de prateleira através do } \\
\text { retardamento do crescimento de fungos }\end{array}$ & $\begin{array}{l}\text { Morangos algumas } \\
\text { outras frutas }\end{array}$ \\
\hline $0,1-1$ & Desinfestação: insetos mortos e esterilizados & $\begin{array}{l}\text { Grãos, frutas e } \\
\text { vegetais. }\end{array}$ \\
\hline $\begin{array}{c}0,025 \\
0,75\end{array}$ & Retarda o amadurecimento & $\begin{array}{l}\text { Abacate, banana, } \\
\text { manga, papaia e } \\
\text { algumas frutas não } \\
\text { citricas. }\end{array}$ \\
\hline $0,15-0,7$ & Elimina Trichinella sp & Porco \\
\hline $0,05-0,3$ & Inibe a germinação & Batata, cebola, alho. \\
\hline
\end{tabular}


A radiação ionizante induz um choque oxidativo nos materiais. Assim, é possivel a priori considerar que antioxidantes possam agir também como radioprotetores em certos sistemas. A eficiência do radioprotetor pode depender, por exemplo, da sua concentração e a capacidade de se combinar com determinados radicais. Os neutralizadores de radicais ("radical scavengers") teriam capacidade radioprotetora, ao reagirem com os radicais livres e efetivamente interceptando ou protegendo os outros solutos presentes (DEL MASTRO, 1989).

\section{OBJETIVO}

O objetivo do presente trabalho é avaliar a ação de substâncias antioxidantes na resposta à radiação dos hidrocolóides agaranas, carragenanas e alginatos utilizados amplamente como aditivos espessantes na indústria de alimentos. As substâncias antioxidantes escolhidas foram ácido ascórbico, extrato vegetal de rosela (Hibiscus sabdariffa L.) e isoflavona de soja.

\section{REVISÃO DA LITERATURA}

\subsection{Polissacarídeos alimentares}

O tratamento por radiação pode ser uma forma rápida e simples de modificar as propriedades químicas, físicas e farmacêuticas de biopolímeros, como por exemplo, o amido (DE KERF et al., 2001).

Muitos dos efeitos benéficos das radiações às vezes são limitados por causa da ação da radiação sobre outras propriedades dos alimentos. Certos aditivos alimentícios são utilizados muitas vezes como espessantes. Tal é o caso dos hidrocolóides agaranas, carragenanas e alginatos, que quando irradiados para melhorar sua qualidade higiênica, podem ter sua viscosidade diminuída por ação da radiação. ALISTE (1999) estabeleceu que a radiação produz uma notória 
diminuição na viscosidade de géis formados por esses hidrocolóides que tinham sido previamente irradiados em pó.

Os três polímeros de carboidratos de organismos marinhos explorados comercialmente são: (1) alginatos, polimeros contendo o ácido manurônico e ácido gulurônico extraídos das algas pardas; (2) as agaranas, polímeros contendo a D-galactose e anidro - L-galactose que são isolados das algas vermelhas; e as (3) carragenanas também obtidos de algas vermelhas (DE RUITIER \& RUDOLPH, 1997).

Recentemente, os avanços na tecnologia de gomas e amidos têm levado ao desenvolvimento de uma grande quantidade de novos produtos e processos. Os esforços em pesquisas nessa área resultaram na descoberta de gomas com melhor viscosidade e gelificação, baixas calorias e estabilidade. $A$ indústria de alimentos funcionais e de bebidas também foi responsável pelo impulso na produção de novos ingredientes.

As gomas são fontes importantes de fibras dietéticas. A sua quantidade de fibras e a baixa caloria aumentaram o interesse em gomas como a acácia, goma lacusta, carragenana e goma guar para aumentar o nivel de fibras. Além de serem fontes de fibras são cada vez mais utilizados sozinhos ou combinados, para melhorar as propriedades físicas dos alimentos.

A grande maioria das gomas utilizadas em alimentos são derivadas de plantas, incluindo carragenanas, pectina, agaranas e alginatos.

As carragenanas foram escolhidas para uso em embutidos, por suas propriedades funcionais, capazes de formar géis em água a baixas concentrações. As carragenanas facilitam a ação da proteína da carne e melhoram a qualidade do produto.

Por serem agentes com alta concentração de fibras e baixas calorias os alimentos preparados a partir dos hidrocóloides como as agaranas, 
carragenanas e alginatos, têm um grande campo de aplicação, como por exemplo, ser utilizados para combater a obesidade. (AHMED, 2005).

Os polissacarídeos hidrossolúveis ou gomas são polimeros de cadeia longa que se dissolvem ou dispersam em água e, quando incorporados em alimentos possuem propriedades como: alteração das caracteristicas reológicas, estabilização de emulsões, promoção de suspensão de partículas, controle da cristalização, inibição da sinerese (exsudação espontânea da água de um gel que está em repouso) de alimentos processados.

Os aditivos polissacaridicos sāo largamente utilizados em alimentos como agentes estabilizantes, gelificantes e espessantes. Nestes se incluem: goma guar, LBG (goma locusta), carragenanas, goma xantana, goma arábica e alginatos (HAINES \& PATEL, 1997) (Tabela 2).

Tabela 2 - Gomas e espessantes comumente usados em alimentos (HAINES \& PATEL, 1997)

\begin{tabular}{|c|c|c|}
\hline Goma & Função & Produtos típicos \\
\hline Alginato & $\begin{array}{l}\text { Estabilizante, agente } \\
\text { espessante }\end{array}$ & $\begin{array}{l}\text { Sorvete, iogurte, leite } \\
\text { aromatizado }\end{array}$ \\
\hline Agarana & $\begin{array}{l}\text { Estabilizante, agente } \\
\text { espessante e gelificante }\end{array}$ & Sorvete, carne enlatada \\
\hline Carragenana & $\begin{array}{l}\text { Estabilizante, agente } \\
\text { espessante e gelificante }\end{array}$ & Sorvete, confeitos e molhos \\
\hline $\begin{array}{l}\text { Goma locusta } \\
\text { (LBG) }\end{array}$ & $\begin{array}{l}\text { Estabilizante, emulsificante, } \\
\text { agente espessante e gelificante }\end{array}$ & $\begin{array}{l}\text { Sorvete, sopas, temperos de } \\
\text { salada, bolos, queijos. }\end{array}$ \\
\hline Goma guar & $\begin{array}{l}\text { Estabilizante de emulsão, } \\
\text { agente espessante e suspensor, } \\
\text { agente avolumador }\end{array}$ & $\begin{array}{l}\text { Sorvete, sopas, temperos de } \\
\text { salada, bolos, queijos. }\end{array}$ \\
\hline Goma arábica & $\begin{array}{l}\text { Para retardar a cristalizaçāo do } \\
\text { açúcar, agente espessante. } \\
\text { emulsificante, estabilizante } \\
\text { vitrificador }\end{array}$ & $\begin{array}{l}\text { Doces, geléias, gelados, } \\
\text { cerveja, soft drinks }\end{array}$ \\
\hline Goma xantana & $\begin{array}{l}\text { Estabilizante, agente } \\
\text { espessante, emulsificante }\end{array}$ & $\begin{array}{l}\text { Laticinios, temperos de } \\
\text { salada, mistura de bolo }\end{array}$ \\
\hline
\end{tabular}


O órgão dos EUA para o controle de alimentos e drogas (FDA) classifica as gomas como aditivos alimentares, geralmente reconhecidos como seguros. Essas gomas, ou polissacarideos hidrossolúveis, usados na indústria de alimentos são obtidos de várias origens como algas, sementes e exudados de árvores (DE KERF et al., 2001).

Cerca de $80 \%$ da produção de hidrocolóides de algas marinhas são utilizados pela indústria alimentícia e outras indústrias relacionadas, enquanto que uma grande porção do restante é consumida em produtos farmacêuticos e cosméticos. Em todos os casos são usados como agentes gelificantes, espessantes, estabilizantes ou emulsificantes (AZERO \& ANDRADE, 1997).

Esses hidrocolóides também podem modular a absorção intestinal da glicose e a resposta insulínica à alimentação, reduzindo o pico de glicemia ao término de uma refeição e aumentando assim o conforto diário dos diabéticos. Outros podem ter efeito laxante, acelerando o trânsito digestivo, ou ainda melhorar o equilíbrio da flora intestinal do cólon, propiciando o crescimento das bactérias bifidas, consideradas como potencialmente benéficas para a saúde e muito utilizadas nos preparados à base de leite (ALGAS, 1997).

\subsubsection{Agaranas}

Ágar-ágar; agar; gelasse; agar do Japão; ou agaranas são um complexo de polissacarídeos extraidos de agarócitos de algas da familia Rhodophiceae (algas vermelhas). Produtores de agaranas são predominantemente as espécies Gelidium, Gracilaria, Acanthopeltis, Ceramium, Pterocladia encontradas nos oceano Pacífico e Índico e no mar do Japão (BUDAVARl et al., 1996).

$\mathrm{Na}$ indústria alimentícia, as agaranas são usadas principalmente como agentes gelificantes e de outra forma como agentes estabilizantes e para controlar a viscosidade. Também são utilizadas em panificação para preparar geléias, marshmallows, doces ou recheios. Devido ao fato do corpo humano não 
digerir facilmente as agaranas, sua contribuição calórica é desprezivel, dessa forma, são freqüentemente incluidas em alimentos dietéticos (McHUGH, 1987).

As agaranas podem ser separadas numa fração gelatinosa neutra, agarose e uma fração sulfatada não gelatinosa, agaropectina (Figura 1) (GLICKSMAN, 1969).

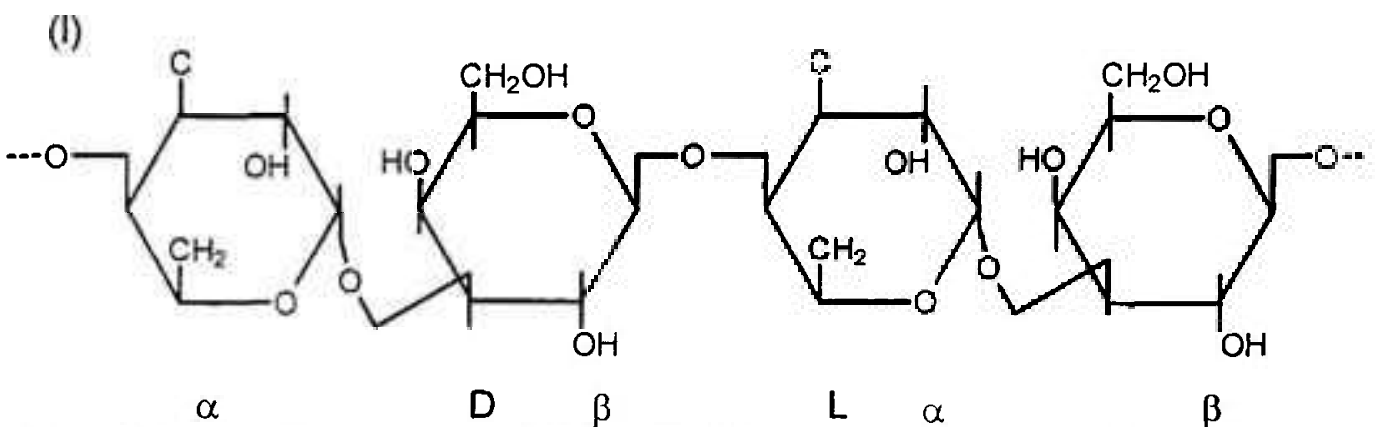

Unidades do dissacarídeo agarobiose unidas por ligações 1-3

(II)

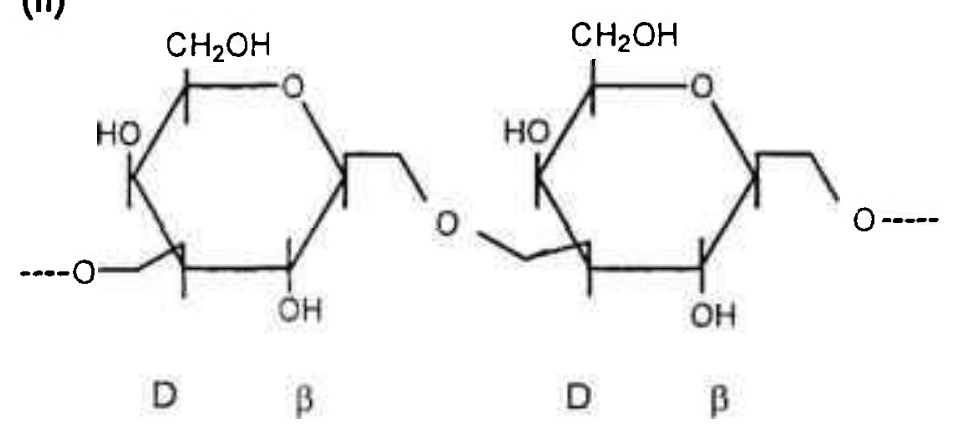

Unidades de D-galactopiranose unidas por ligações 1-3

Figura 1 - Fórmulas estruturais da agarose (I) e agaropectina (II) (GLICKSMAN, 1969).

Da mesma forma que a nomenclatura das carragenanas, essa divisão dada às agaranas, também é contestada, visto que surgiu em analogia ao amido. Acredita-se que sua estrutura é uma extensão complexa de cadeias de polissacarídeos tendo alternadamente ligaçōes $\alpha-(1 \rightarrow 3)$ e $\beta-(1 \rightarrow 4)$ e variando no conteúdo total de carga. São notados três extremos da estrutura, chamados de 
agarose neutra, agarose piruvatada tendo uma leve sulfatação, e galactana sulfatada (GLICKSMAN, 1969; BUDAVARI et al., 1996).

As agaranas são insolúveis em água fria, porém expandem-se consideravelmente e absorvem uma quantidade de água de cerca de até vinte vezes o seu próprio peso. A dissolução em água quente $\left(>90^{\circ} \mathrm{C}\right)$ é rápida e podese observar a formação de um gel firme a concentrações tão baixas quanto $0,5 \%$ (McHUGH, 1987).

A viscosidade das agaranas é acentuadamente influenciada e dependente da fonte de matéria prima. A viscosidade a temperatura abaixo do seu ponto de gelificação é relativamente constante em pH 4,5 a 9, e não é muito afetada dentro da faixa de $\mathrm{pH}$ entre 6 a 8 . Entretanto, iniciada a gelificação, a viscosidade a temperatura constante aumenta com o tempo. Da mesma forma que as carragenanas, sua viscosidade é inversamente proporcional à temperatura e também aumenta exponencialmente com a concentração (McHUGH, 1987).

Em relação ao poder de gelificação as agaranas são notáveis dentre os hidrocolóides. O gel pode ser obtido em soluções muito diluídas contendo uma fração de 0,5 a $1,0 \%$ de agaranas. Ele é rígido, possui formas bem definidas e pontos de fusão e gelificação precisos. Ademais demonstra claramente os interessantes fenômenos de sinerese (perda espontânea da água de um gel que está em repouso) e histérese. A gelificação ocorre a temperaturas muito abaixo da temperatura de fusão. Uma solução de $1,5 \%$ de agaranas forma um gel ao ser resfriado para uma temperatura de 32 a $39^{\circ} \mathrm{C}$ e a fusão de tal gel não ocorre a temperaturas inferiores a $85^{\circ} \mathrm{C}$. Este retardo de histerese é uma propriedade das agaranas valorizada nos últimos tempos que encontra uma variedade de usos em aplicações alimentícias. A força de gel das agaranas é influenciada pela concentração, tempo, pH e conteúdo de açúcar (MORAIS et al., 1989a). 
Alguns outros usos das agaranas são:

$\begin{array}{ll}\text { - } & \text { substituto para gelatina, cola de peixe, etc.; } \\ \text { em cosméticos; } & \text { para fazer emulsões incluindo fotográficas, géis } \\ \text { - } & \text { em produção de encapsulados medicinais e } \\ \text { - } & \text { como base para molde de impressão dental; } \\ \text { - } & \text { como inibidor de corrosão; } \\ \text { - } & \text { naderador para sedas e papéis; } \\ \text { - } & \text { em adesivos; } \\ \text { - } & \text { como meio nutriente para cultura de bactérias; } \\ \text { cães e gatos, e tem propriedades de calmante (BUDAVARI et al., } \\ \text { 1996). }\end{array}$

\subsubsection{Carragenanas}

O nome carragenana é derivado da cidade costeira irlandesa de Carragheen.

As carragenanas são um grupo de carboidratos naturais que estão presentes na estrutura de certas variedades de algas vermelhas (Rhodophycea). Estes carboidratos têm a particularidade de formar colóides espessos a géis em meios aquosos a baixas concentrações. Devido a essas propriedades funcionais, as carragenanas são amplamente usadas como ingredientes em diversas aplicações (MORAIS \& PIZZINATTO, 1989b).

As três principais carragenanas comerciais são $1-, k$ - e $i$-carragenana. Cada uma destas tem um nome comercial comum, e um nome que especifica a principal substituição padrão. Essa nomenclatura com prefixos gregos é usada 
universalmente, incluindo em regulamentação e legislação, mas está se tornando crescentemente confuso do ponto de vista científico porque não é lógico, é inflexivel e não torna posșivel a descrição de polímeros sem ambigüidade. KNUTSEN et al.(1994) propuseram uma nomenclatura alternativa para polissacarídeos de algas vermelhas que é baseada em abreviações lógicas e na nomenclatura mundialmente aceita da IUPAC (International Union of Pure and Applied Chemistry) (McNAUGHT, 1996). Embora essa nova nomenclatura seja muito melhor que o uso da palavra carragenana com diferentes prefixos gregos, será difícil de ser aceita em nomes comerciais de polímeros de algas que são usados como ingredientes alimentícios, devido ao sistema antigo estar em uso há muito tempo (DE RUITIER \& RUDOLPH, 1997).

As familias estruturais de $\kappa$ e $\lambda$ são identificadas com base na posição dos sulfatos e na presença/ausência de anidrogalactose. A família $\kappa$ consiste de carragenanas $\kappa, \imath, \mu, \nu$ das quais a $\kappa$ e $\imath$ são as predominantes e caracterizam-se pelas unidades repetidas de 4-sufato- $\beta$-D-galactopiranosil( $1 \rightarrow 4)-\alpha-D$-galactose ligadas por ligações $(1 \rightarrow 3)$. A unidade de galactose varia de 3,6 -anidro- $\alpha$-Dgalactose para a forma $\kappa$ e de 3,6-anidro- $\alpha$-D-galactose-2-sulfato para a forma $\mathrm{\imath}$. Por causa da estrutura helicoidal terciária que permite a gelificação, a familia $\kappa$ é a de maior importância comercial (DE RUITIER \& RUDOLPH, 1997; BUDAVARI et al., 1996).

Nas figuras 2, 3 e 4, temos as principais frações de carragenanas com suas unidades poliméricas características, destacando-se as mais importantes comercialmente, respectivamente a $\kappa$ - $\imath$ - e $\lambda$-carragenana (McHUGH, 1987). 


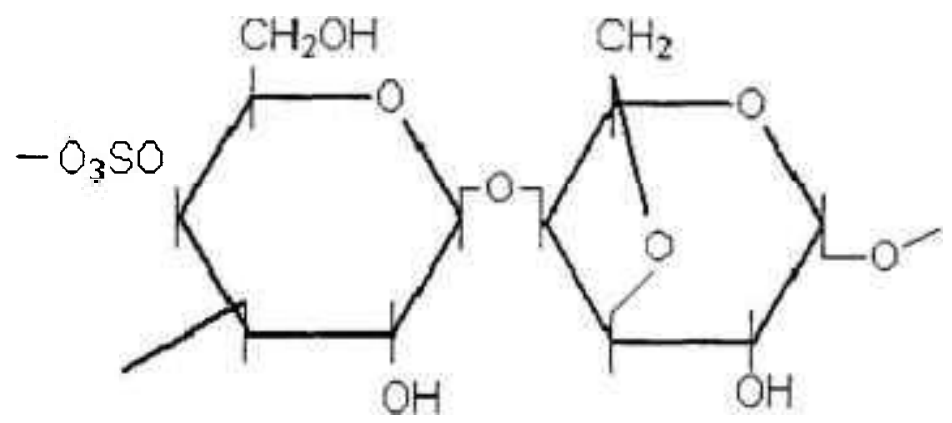

Figura 2 - Fórmula estrutural da k-carragenana (McHUGH, 1987).

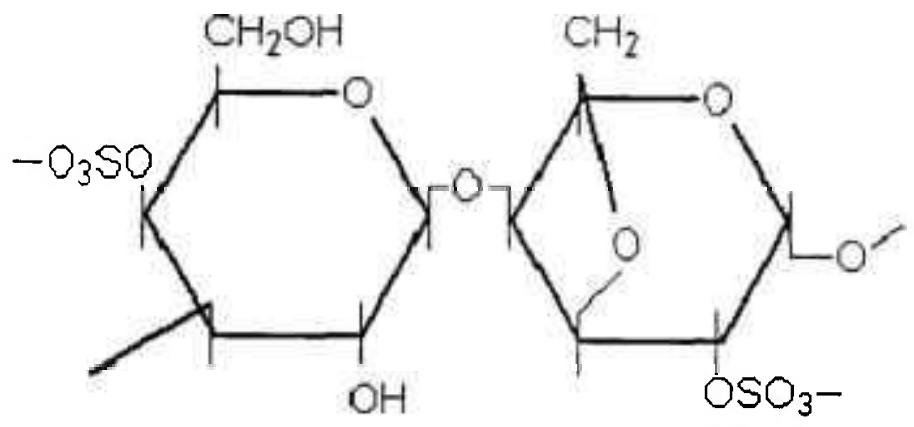

Figura 3 - Fórmula estrutural da i-carragenana (McHUGH, 1987).

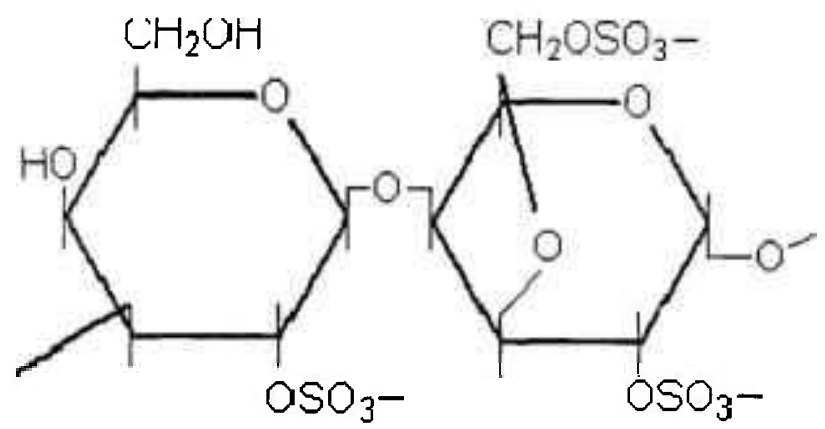

Figura 4 - Fórmula estrutural da $\lambda$-carragenana (McHUGH, 1987).

O conhecimento da estrutura detalhada das carragenanas é limitado. Em adição a D-galactose e 3,6-anidro-D-galactose como os principais resíduos de açúcar e sulfato como o principal substituto, outros resíduos de carboidratos (por exemplo, xilose, glucose e ácidos urônicos) e substitutos estão presentes. Esse 
conhecimento é importante porque a estrutura das carragenanas influencia suas propriedades funcionais, que por sua vez influencia seu valor comercial (DE RUITIER, G. A.; RUDOLPH, 1997; THERKELSEN, 1993; BOISSON-VIDAL, 1995).

A $\kappa$-carragenana comercial típica possui $22 \%$ de sulfato em peso, a 1carragenana $32 \%$ e a $\lambda$-carragenana $38 \%$, apesar de que grandes variações podem ocorrer devido a diferenças entre espécies ou grupos de algas marinhas. As diferenças entre os niveis de sulfato de cada um dos três tipos de carragenana e os niveis esperados baseados nas suas estruturas indicam claramente que as amostras de carragenana não são estruturas simples, mas polissacarideos complexos que tem diferentes quantidades de ésteres de sulfato em diferentes posições e com diferentes distribuições (DE RUITIER \& RUDOLPH, 1997).

Os grupos ester de sulfato e os anéis de 3,6-anidrogalactose (3 AG) são essenciais para as propriedades físico-químicas das respectivas carragenanas na sua formação de hélice e consequentemente suas propriedades reológicas e aplicações (LE QUESTEL et al., 1995; VIEBKE et al., 1995).

As carragenanas têm um comportamento hidrofilico, são solúveis em água e insolúveis em solventes orgânicos. A solubilidade é influenciada pela quantidade de grupos sulfatados que tem características mais hidrofilicas e dos 3,6 AG que são menos hidrofilicos. Por essa razão a k-carragenana é menos solúvel que a t-carragenana e esta menos solúvel que a $\lambda$-carragenana (McHUGH, 2003).

Devido ao fato de possuirem um alto conteúdo de 3,6 AG, tipicamente, a k-carragenana forma géis firmes e quebradiços que podem sofrer sinerese, enquanto que a ı-carragenana forma géis elásticos e macios que usualmente não sofrem sinerese (DE RUITIER \& RUDOLPH, 1997).

A $\lambda$-carragenana, pela ausência de 3,6 AG não gelifica, e devido ao seu alto grau de sulfatação, é a fração mais solúvel em água e leite frio, 
proporcionando a esses sistemas alta viscosidade e por esse fato são utilizadas como agentes espessantes (DE RUITIER \& RUDOLPH, 1997).

As $\kappa$-carragenanas são altamente reativas com as proteínas do leite $\mathrm{e}$ em particular com a к-caseína, o que explica se dissolverem facilmente em leite. Essa alta reatividade no leite se deve à forte interação eletrostática entre os grupos sulfato da carragenana com a caseína (DE RUITIER \& RUDOLPH, 1997).

As carragenanas formam soluções pseudoplásticas em água. A viscosidade dessas soluções depende do peso molecular médio e o do tipo de carragenana. A $\lambda$-carragenana é a que produz maior viscosidade, seguida pela 1 e к- (McHUGH, 2003).

Há uma grande variedade de carragenanas comerciais, podendo ser encontradas em viscosidades variando de aproximadamente $5 \mathrm{cP}$ a $800 \mathrm{cP}$ quando medidas à concentração de $1,5 \%$ e $75^{\circ} \mathrm{C}$. As soluções de carragenanas que possuem viscosidades menores que $100 \mathrm{cP}$ tem propriedades de fluxo próximas as Newtonianas. Sua viscosidade é inversamente proporcional à temperatura e aumenta exponencialmente com a concentração (McHUGH, 1987).

Todas as carragenanas se dispersam em água fria e aquecendo-se acima de $80^{\circ} \mathrm{C}$ alcança-se sua completa solubilização. Durante o resfriamento se forma uma estrutura molecular tipo dupla hélice que se alinham para formar em presença de certos cátions, uma rede tridimensional tipo gel em meio aquoso.

Este mecanismo de gelificação é básico para as carragenanas tipo kappa e iota. Estas carragenanas formam géis acima de 0,5\% em água e acima de $0,2 \%$ em leite. Os ions de cloreto e potássio são necessários para a gelificação dessas carragenanas em água, mas não no leite. A carragenana lambda não gelifica a estas baixas concentrações (McHUGH, 2003).

Os géis formados são termo-reversiveis e podem ser submetidos a ciclos de aquecimento e resfriamento com pouca perda na sua estrutura de gel. 
As temperaturas de fusão e gelificação dependem da concentração de cátions sendo diretamente proporcional ao conteúdo de cátions em solução ( $\mathrm{McHUGH}$, 2003).

As carragenanas podem ser utilizadas como: gelificantes, emulsificantes, e agentes estabilizantes e indutores da viscosidade em alimentos e não alimentos, mas especialmente em leite ou sistemas aquosos (BUDAVARI et al., 1996)

Devido às suas extraordinárias propriedades funcionais as carragenanas são utilizadas principalmente como ingredientes na indústria alimentícia, cosmética e farmacêutica (McHUGH, 2003).

Dentro da indủstria alimenticia existem vários usos das carragenanas tanto em produtos aquosos quanto em produtos lácteos. Como exemplo de utilização pode-se citar: produção de sobremesas tipo gelatina, sucos e doces de frutas, carnes processadas (presuntos, salsichas, hambúrgueres, surimi de pescado e nuggets de frango), sobremesas de géis em leite, suspensão e estabilização em leite (achocolatados, leites reconstituidos em pó), emulsões lácteas (sorvetes, em cremes como estabilizantes da emulsão e da espuma), produtos lácteos fermentados (McHUGH, 2003).

\subsubsection{Alginatos}

O alginato, amplamente encontrado na natureza, é um polissacarídeo gelificante extraído de algas marinhas pardas tais como a Macrocystis pyrifera, Lessoniacea (alga marinha gigante,) ou da alga marinha Laminaria digitata, Laminariacea ou de algas marinhas Laminaria saccharina (BUDAVARI et al., 1996).

Os alginatos são compostos de três tipos de grupos de polímeros denominados poliglucuronato (poli-G), polimannuronato (poly-M) e o copolimero de poli-G e poly-M alternadamente (HAUG et al., 1967a). 
Os usos dos alginatos em alimentoș, são baseados principalmente na formação de filme, poder espessante, gelificante, estabilizante e propriedades coloidais gerais. Como espessante é usado em molhos, xaropes e coberturas para sorvetes, nos recheios de tortas (onde reduz a retenção de umidade pela massa), na mistura de bolo (engrossando a massa e ajudando na retenção de umidade), na carne enlatada e em vegetais (onde pode também dar uma ação espessante temporária ou retardada) (McHUGH, 1987).

O ácido algínico e seus vários sais, coletivamente designados de algina, constituem-se em ficocolóides caracteristicos de algas pardas, onde impregnam a parede celular e preenchem os espaços intercelulares (OLIVEIRA FILHO \& QUÉJE, 1978).

O ácido algínico é um polímero linear do ácido $\beta-(1 \rightarrow 4)-D-$ manusilurônico e resíduos do ácido $\alpha-(1 \rightarrow 4)$-L-gulosilurônico. As proporções relativas de cada um variam com as fontes botânicas e com o estado de maturação da planta (BUDAVARI et al., 1996).

No ácido algínico ocorrem três tipos de segmentos de polímeros. Estes são constituídos pelos ácidos manurônico (Figura 5) e gulurônico (Figura 6) (HAUG, 1966; HAUG et al., 1967a; HAUG et al., 1967b).

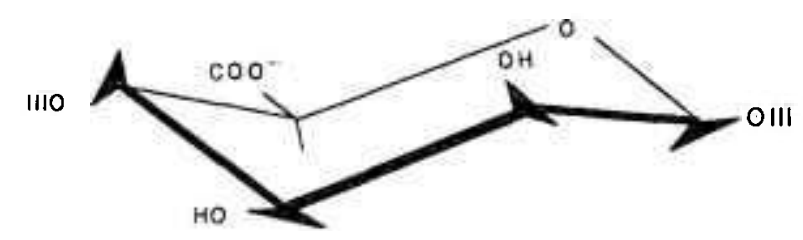

Figura 5 - Fórmula estrutural do ácido manurônico (HAUG, 1966; HAUG et al., 1967a; HAUG et al., 1967b). 


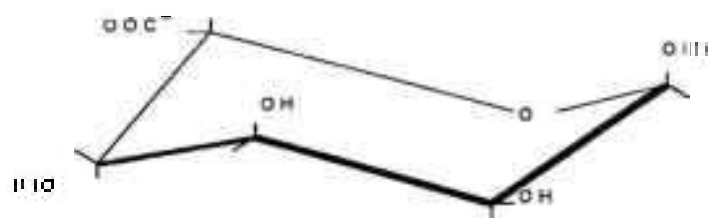

Figura 6 - Fórmula estrutural do ácido gulurônico (HAUG, 1966; HAUG et al., 1967a; HAUG et al., 1967b).

Um segmento desses polimeros consiste essencialmente de unidades de ácido $\delta$-manurônico; um segundo segmento de unidades de ácido $\lambda$ gulurônico; e o terceiro segmento consiste de unidades alternadas de resíduos de ácido $\delta$-manurônico e $\lambda$-gulurônico respectivamente (HAUG, 1966; HAUG et al., 1967a; HAUG et al., 1967b) (Figuras 7, 8 e 9).

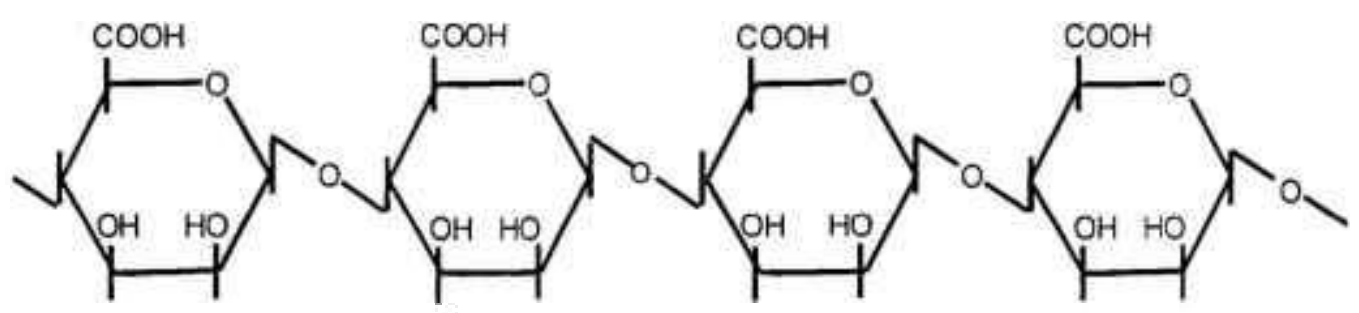

Figura 7 - Segmento de polimeros no ácido algínico constituído essencialmente de unidades de ácido $\delta$-manurônico (-M-M-M-M-M-) (HAUG, 1966; HAUG et al., 1967a; HAUG et al., 1967b). 


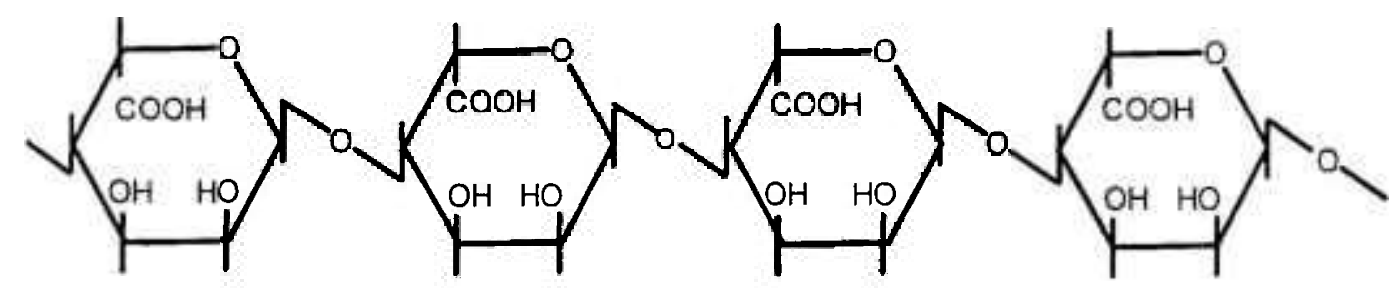

Figura 8 - Segmento de polimeros no ácido alginico constituido essencialmente de unidades de ácido $\lambda$-gulurônico (-G-G-G-G-G-) (HAUG, 1966; HAUG et al., 1967a; HAUG et al., 1967b).

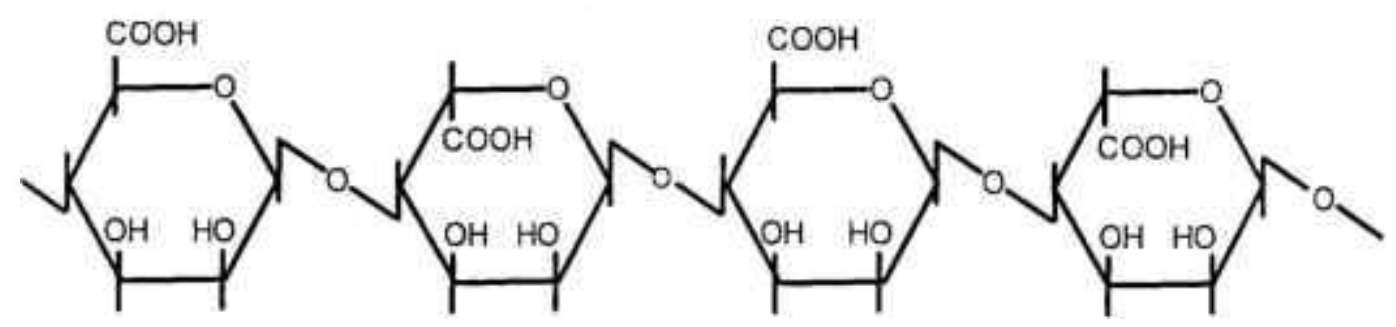

Figura 9 - Segmento de polímeros no ácido algínico constituído de unidades alternadas de residuos de ácido $\lambda$-gulurônico e $\delta$-manurônico (-M-G-MG-M-) (HAUG, 1966; HAUG et al., 1967a; HAUG et al., 1967b).

Como já foi citado, a composição do ácido alginico obtido de algumas algas pardas comercialmente importantes, varia conforme a fonte de extração. Há variação na quantidade e na relação entre os ácidos manurônico e gulorônico presentes. As diferenças em composição e estrutura fina explicam as diferenças nas propriedades e funcionalidade de alginatos isolados de diferentes espécies de algas pardas (HAUG \& LARSEN, 1962; HAUG, 1964).

O alginato de sódio forma soluções de alta viscosidade aparente mesmo a baixas concentrações devido ao seu alto peso molecular e a natural rigidez de suas moléculas, as suas soluções são pseudoplásticas (McHUGH, 1987). Ou seja, o comportamento pseudoplástico das soluçōes de alginato, ocorre nas concentrações comumente utilizadas, na maioria das suas aplicações. A 
solução flui mais prontamente, quanto mais é agitada ou bombeada (a viscosidade decresce com o aumento da taxa de cisalhamento) (McHUGH, 1987).

A interação dos ions de cálcio com os alginatos pode produzir géis com diferentes propriedades reológicas (MACDOWELL, 1975). Para uma adequada concentração de alginato, o aumento da quantidade de ions de cálcio produz géis com propriedades independentes do tempo, e mais adições de cálcio formam uma estrutura permanente de gel. Os sistemas gel-reversivel são particularmente interessantes devido a que alguns géis mostram tixotropia e recuperam sua estrutura de gel depois da diminuição da força de cisalhamento, no entanto outros mostram reodestruição e não retornam ( $\mathrm{McHUGH}, 1987)$.

Uma das mais utilizadas e importantes propriedades dos alginatos é a habilidade de formar géis pela reação com sais de cálcio. Esses géis, que se assemelham a sólidos na manutenção da sua forma e resistência a tensão, consistem de quase $100 \%$ de água (normalmente, 99,0 a $99,5 \%$ de água e 0,5 a $1,0 \%$ de alginato) (McHUGH, 1987).

Um gel, na terminologia clássica dos colóides, é definido como um sistema que deve suas propriedades caracteristicas a rede de reticulação ("crosslinking") de cadeias poliméricas que se formam no ponto de gel (HERMANS, 1949). Embora uma considerável quantidade de pesquisas tenham sido realizadas para elucidar a natureza da reticulação e para determinar a estrutura dos géis de alginato (McHUGH, 1987) ainda persistem muitas incertezas.

O alginato é usado na indústria alimentícia em: cremes, pudins, sorvetes cremosos, queijos, preservação de peixes e carnes, produtos de confeitaria, clarificadores e estabilizadores de bebidas fermentadas, maioneses, xaropes, molhos e produtos dietéticos entre outros (OLIVEIRA FILHO \& QUÉJE, 1978). Na manufatura de sorvetes funciona como um colóide estabilizante, assegurando uma textura cremosa e prevenindo o crescimento de cristais de gelo (BUDAVARI et al., 1996). 
$\mathrm{Na}$ indústria farmacêutica os alginatos são utilizados em cápsulas, suspensão de antibióticos e de outras substâncias insolúveis, linhas e gazes cirúrgicas, impressões dentárias, cosméticos, etc. (OLIVEIRA FILHO \& QUÉJE, 1978). Podemos citar vários outros usos tais como: em cerâmicas, tintas, borracha, bebidas, moldes especiais, produtos de limpeza, polidores, filmes, revestimentos, adesivos, papéis, em tintura de tecidos de brim; na floculação dos sólidos no tratamento da água; como agente moderador; espessante; estabilizador de emulsões; agente suspensor em bebidas suaves (McHUGH, 1987; BUDAVARI et al., 1996).

Como descrito acima, os alginatos tem ampla aplicação não só nas indústrias alimentícias, de bebidas, farmacêuticas, mas também na bioengenharia. Oligossacarídeos obtidos pela despolimerização enzimática de alginatos, chamados de oligoalginatos, foram descritos como sendo capazes de, por exemplo, estimular o crescimento de um tipo de bactéria e promover a germinação de plantas (HIENA et al., 2000).

As técnicas de irradiação podem ser uma ferramenta útil para a degradação de vários tipos de polímeros, incluindo polissacarídeos naturais como 0 alginato. HIENA et al.(2000) constatou que na irradiação de alginato no meio líquido (solução a $4 \%$ ) ocorre uma degradação aproximadamente dez vezes maior comparado com amostras irradiadas na forma de pó. No entanto do ponto de vista prático da utilização das técnicas de radiação para produção de alginato degradado, a aplicação da energia da radiação seria logisticamente mais adequada no estado sólido do que no líquido. Nesse estudo conclui-se que o alginato degradado preparado pelo método da radiação, pode agir como agente promotor do crescimento em plantas. 


\section{2 Ácido ascórbico}

O ácido L-ascórbico, ou vitamina C (Figura 10) è amplamente encontrado em plantas e no reino animal. As frutas citricas, acerola, morango, amora e framboesa e folhas frescas de chá, são reconhecidamente boas fontes de ácido ascórbico (BUDAVARI et al., 1996).<smiles>O=C1OC([14CH2]C(O)CO)C(O)=C1O</smiles>

Figura 10 - Fórmula estrutural do ácido L-ascórbico

O acido ascórbico possui sabor levemente ácido; é estável ao ar, quando seco. Em soluçōes impuras e em vários produtos naturais a vitamina se oxida quando exposta ao ar e à luz. O acido ascórbico atua, numa função protetora, na acumulação de ferro na medula óssea, baço e fígado; na produção de colágeno (proteína do tecido conjuntivo); na manutenção da resistência a doenças bacterianas e virais; na formação de ossos e dentes; na manutenção dos capilares sanguíneos; entre outras (BUDAVARI et al., 1996; SILVA et al., 1995).

A vitamina $C$ apresenta ações benéficas sobre o sistema imunológico, no metabolismo lipídico e na prevenção de câncer. É utilizada nos alimentos como agente antimicrobiano e antioxidante (BUDAVARI et al., 1996; SILVA et al., 1995). 
O ácido ascórbico foi isolado pela primeira vez sob forma de pó cristalino branco, em 1922, pelo pesquisador húngaro Szent-Györgi. As fontes mais importantes de ácido ascórbico, se encontram no reino vegetal. Os vegetais folhosos como a bertalha, o brócolis, a couve, o nabo, as folhas de mandioca e 0 inhame, legumes como pimentōes amarelos e vermelhos e frutas como a cerejado-pará, o caju, a goiaba, a manga, a laranja, a acerola, etc., são boas iontes de vitamina C (SILVA et al., 1995).

\subsection{Rosela (Hibiscus sabdariffa L.)}

$\mathrm{Na}$ Índia ocidental e em alguns lugares dos trópicos os cálices da planta Rosela (Hibiscus sabdariffa L.) são utilizados frescos para fazer vinho, geléia, xarope e bolos de rosela. A rosela seca, é usada para chá, geléia, sorvete, molhos e outras sobremesas. A parte tenra e as hastes são consumidas como salada. A rosela é descrita como sendo antiséptica, coagulante, digestiva, diurética, emoliente, purgativa, e tônica, e é um remédio popular para dentre outros males, abscessos, debilidade, febre, hipertensão, e neurose (DUKE \& ATCHELY,1984; PERRY, 1980; WATT \& BREYER-BRANDWIJK, 1962). Cada $100 \mathrm{~g}$ de fruta contém 49 calorias, $84,5 \mathrm{~g}$ de água, $1,9 \mathrm{~g}$ de proteína, $0,1 \mathrm{~g}$ de gordura, $12,3 \mathrm{~g}$ de carboidratos totais, $2,3 \mathrm{~g}$ de fibras, $1,2 \mathrm{~g}$ de cinzas, $1,72 \mathrm{mg}$ de $\mathrm{Ca}, 57 \mathrm{mg}$ de $\mathrm{P}, 2,9 \mathrm{mg}$ de $\mathrm{Fe}, 300 \mu \mathrm{g}$ de $\beta$-caroteno equivalente e $14 \mathrm{mg}$ de ácido ascórbico. O karkade (flores secas sem o ovário) contém $13 \%$ de uma mistura de ácidos citrico e málico, duas antiocianinas, gossipetina (hidroxiflavona) e hibiscina, e 0,004-0,005\% de ácido ascórbico.

O extrato de hibisco, também utilizado para dar cor e sabor a bebidas, contém os mesmos componentes antioxidantes do vinho tinto, incluindo os flavonóides, polifenóis e antocianinas. Comprovou-se que ele pode prevenir a oxidação de lipoproteinas de baixa densidade (LDL), ou "mau" colesterol (CHANG-CHE et al., 2004).

As antocianinas, o maior grupo de pigmentos hidrossolúveis naturais de plantas, são responsáveis por cores atrativas das flores, frutos (frutas 
vermelhas) e vegetais, contribuindo amplamente para a qualidade estética dos seus derivados (GRADINARU et al., 2003).

Alimentos produzidos com presumivel ação benéfica na prevenção de moléstias do coração estão crescendo à taxa anual de $7,6 \%$ de acordo com um órgão de pesquisa inglês. A previsão é de que as vendas na Grã Bretanha atinjam 212 milhões de euros em 2007 (CHANG-CHE et al., 2004).

O Hibiscus sabdariffa é cultivado no mundo todo, com os maiores produtores no Sudão, Egito, China, Índia e Tailândia. Em medicina tradicional foi previamente utilizada no tratamento de hipertensão e problemas de fígado, apesar de ainda existirem poucas comprovações científicas desses fatos. Suas propriedades de diminuir o colesterol ainda podem ser contestadas, porem seu potencial antioxidante é amplamente reconhecido (CHANG-CHE et al., 2004).

\subsection{Isoflavonas de soja}

Os produtos de soja contém fitoquímicos incluindo genisteína (Figura 11) e daidzeína (Figura 12) que pertencem à classe de componentes fenólicos chamados isoflavonas (BAZZOLI et al., 2002). A ingestão de Isoflavonas e proteinas de soja é associada, por estudos estatisticos à redução do risco de doenças crônicas como o cancer, provavelmente devido a sua atividade celular antioxidante (FRITZ et al., 2003; HENDRICH, 2002).

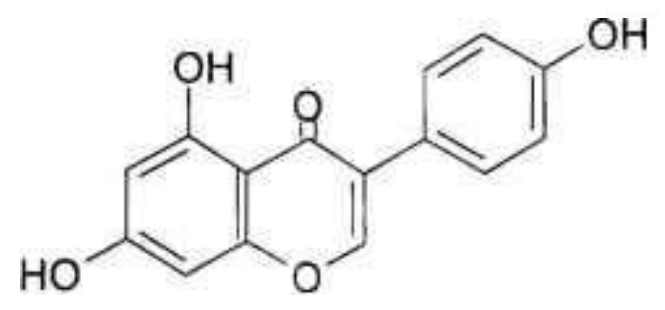

Figura 11 - Fórmula estrutural da genisteína (BAZZOLI et al., 2002). 


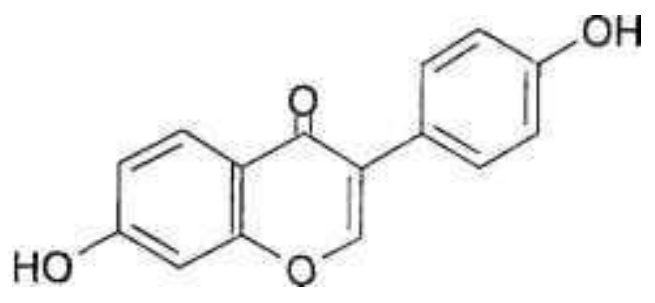

Figura 12 - Fórmula estrutural da daidzeina (BAZZOLI et al., 2002).

As isoflavonas de soja são estudadas extensivamente devido a seus possiveis benefícios para a saúde humana. A genisteína, a aglicona em maior quantidade, é o componente que tem recebido mais atenção (RIMBACH et al., 2004), e é considerado um fitoestrógeno, ou seja, seria um correpondente vegetal ao hormônio feminino (BUDAVARI et al., 1996).

A genisteína é a aglicona (aglucona) da genistina. A isoflavona é encontrada naturalmente como o glicosídeo genistina como os glicosideos 6"-Omalonilgenistina e 6"-O-acetilgenistina. A genisteina e os seus glicosideos são encontrados principalmente em legumes como soja e grão de bico. A soja e os alimentos de soja são as fontes principais dessas substâncias. Alimentos de soja não fermentados, como o "tofu", contêm altos niveis dos glicosídeos da genisteína, enquanto que produtos fermentados como "miso", contêm altos niveis de aglicona .

A genisteína, quando comercializada como complemento nutricional, é apresentada principalmente na forma do seu glicosideo genistina. Reporta-se como tendo atividades estrogênicas e antioxidantes. Também pode possuir atividades anticarcinogênica, anti-aterogênica e anti-osteoporótica. Em ensaios in vivo $\epsilon$ in vitro mostrou atividades estrogênicas fracas. In vivo, sua atividade estrogênica é um terço da gliciteina e quatro vezes maior que a da daidzeina (nttp://www.pdrhealth.com/drug_info/nmdrugprofiles/nutsupdrugs/gen_0118.shtml, 2005). 
Foi descrito que a genisteína tem diversas atividades antioxidantes (HARBORNE \& WILLIAMS, 2000). Essa isoflavona seria capaz de agir como bloqueadora das espécies reativas do oxigênio e inibidora da peroxidação lipídica. Esse composto também inibiria o ânion superóxido gerado pela enzima xantina oxidase. Realizando-se experimentos em animais, constatou-se que a genisteina aumenta a atividade antioxidante das enzimas superóxido dismutase, glutationa peroxidase, catalase e glutationa reductase. A possivel atividade anti-aterogênica da genisteína pode ser atribuída, em parte a sua atividade antioxidante. A genisteina possivelmente possui alguma atividade indutora da diminuição dos lipideos, mas esse mecanismo ainda não esta claro. A fraca atividade estrogênica da genisteina poderia contribuir para sua possivel ação anti-aterogênica.

O leve efeito estrogênico da genisteína pode ajudar na proteção contra a osteoporose promovendo o aumento da densidade óssea. No entanto, esse possivel mecanismo da genisteína como anti-osteoporótico ainda não esta claro. Há, no entanto dados preliminares sugerindo que isoflavonas de soja incluindo a genisteina, podem auxiliar em alguns problemas associados à menopausa incluindo osteoporose (http://www.pdrhealth.com/drug_info/nmdrugprofiles/ nutsupdrugs/gen_0118.shtml, 2005).

Numerosas pesquisas e dados epidemiológicos sugerem que a genisteina bem como uma dieta contendo isoflavonas, podem ser úteis no tratamento e prevenção de alguns tipos de câncer, principalmente câncer de mama e de próstata (PETERSON \& BARNES, 1991) (BARNES, 1998). Outros estudos por sua vez demonstram que a proteção que a população asiática possui é perdida na segunda geração desses asiáticos que emigraram para os EUA, coincidindo com a mudança de dieta.

Alguns pesquisadores concluiram que a exposição perinatal a genisteína pode conferir efeitos protetores permanentes contra o câncer de mama. Especulou-se que especificamente em relação esse tipo de câncer, os efeitos protetores poderiam estar relacionados ao consumo precoce de 
genisteína. Porem mais estudos são necessários para esclarecer esse ponto de vista (http://www.pdrhealth.com/drug_info/nmdrugprofiles/nutsupdrugs/gen_ 0118.shtml, 2005).

Pode-se encontrar a genisteína em diferentes formulações. Uma formulação padrão de isoflavona de soja contém genisteína principalmente na forma de genistina, assim como daidzina e glicitina. As porcentagens das várias isoflavonas presentes nessa formula de isoflavona de soja refletem a porcentagem dessas substancias como são encontradas na soja e são: genistina aproximadamente $50 \%$; daidzina, aproximadamente $38 \%$; e glicitina, aproximadamente $12 \%$. Uma dose típica de $50 \mathrm{mg}$ de isoflavona de soja fornece $25 \mathrm{mg}$ de genistina, $19 \mathrm{mg}$ de daidzina e aproximadamente $6 \mathrm{mg}$ de glicitina. (http://www.pdrhealth.com/drug_info/nmdrugprofiles/nutsupdrugs/gen_0118.shtml, 2005).

\subsection{Radiólise da água}

Os efeitos biológicos das radiações ionizantes podem ser causados por ação direta (os elétrons de recuo ionizam diretamente as moléculas alvo) ou por ação indireta. $A$ interação da radiação em sistemas biológicos é eminentemente decorrente do efeito indireto da radiação, isto é, a ação primária seria a absorção da radiação pelas moléculas de água (HALL, 1994). Assim, é da maior importância conhecer a seqüência de eventos que ocorrem desde o depósito inicial de energia da radiação no meio aquoso.

Quando a radiação ionizante interage com as moléculas de água, esta fica ionizada:

$$
\mathrm{H}_{2} \mathrm{O} \rightarrow \mathrm{H}_{2} \mathrm{O}^{+}+e^{-}
$$

Os raios $X$ e $\gamma$ são radiações "indiretas"; o primeiro passo na sua absorção é a produção de elétrons rápidos de recuo (e-). $\mathrm{O} \mathrm{H}_{2} \mathrm{O}^{+}$é um radical-ion. Um ion é um átomo ou molécula que é eletricamente carregada por causa de ter 
perdido um elétron. Um radical livre contém um elétron desemparelhado na sua órbita externa, como resultado do qual é altamente reativo. $\mathrm{O} \mathrm{H}_{2} \mathrm{O}^{+}$é carregado e tem um elétron desemparelhado, conseqüentemente ele é tanto um ion quanto um radical livre. Radicais-ions tem uma meia-vida extremamente curta, da ordem de $10^{-10}$ segundos. Eles decaem para formar radicais livres que não tem carga mas que ainda possuem um elétron desemparelhado. No caso da água, o radicalion reage com outra molécula de água para formar o radical hidroxila altamente reativo $(\mathrm{OH} \bullet)$ :

$$
\mathrm{H}_{2} \mathrm{O}^{+}+\mathrm{H}_{2} \mathrm{O} \rightarrow \mathrm{H}_{3} \mathrm{O}^{+}+\mathrm{OH}
$$

O radical hidroxila possui nove elétrons sendo apenas um desemparelhado. Ele é um radical livre altamente reativo e pode difundir uma curta distância até atingir um alvo crítico ou uma molécula de soluto. É sugerido que $2 / 3$ do dano ao DNA em moléculas de mamíferos provenha da ação do radical hidroxila. As evidências para esta suposição surgem a partir de experimentos com bloqueadores de radicais livres, que são capazes de reduzir os efeitos da radiação. A ação indireta da radiação pode ser modificada por sensibilizadores ou protetores químicos (BORSA et al., 2004). Assim, o efeito da radiação pode ser descrito da seguinte maneira:

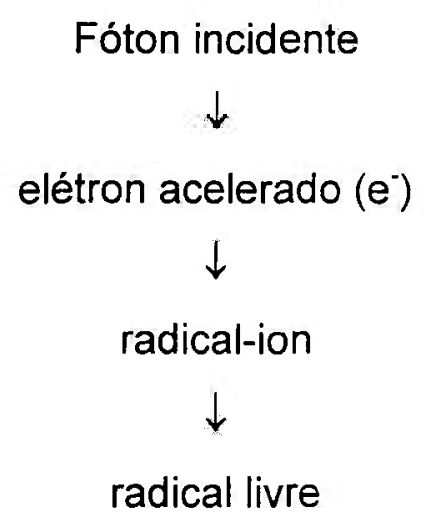

mudanças químicas decorrentes da quebra de ligações

efeitos biológicos 
Há enormes diferenças na escala de tempo que envolve cada um desses eventos. A física do processo, a ionização inicial, pode transcorrer em $10^{-15} \mathrm{~s}$. Os radicais-ions, por sua vez, tem uma meia vida de ao redor de $10^{-10} \mathrm{~s}$, e os radicais livres talvez $10^{-5} \mathrm{~s}$. O evento a partir da quebra de ligações químicas até a expressão do efeito biológico pode levar segundos, horas, meses ou mais tempo.

A água esta presente na maioria dos alimentos. Em vários vegetais está numa proporção de $90 \%$, em frutas $80 \%$, em carne $60 \%$ e em pães $40 \%$. Dessa forma a radiólise da água tem particular interesse na irradiação de alimentos. Os produtos da radiólise da água no total são:

$\begin{array}{ll}\mathrm{OH} \bullet & \text { radical hidroxila; } \\ \mathrm{e}^{-} \mathrm{aq} & \text { elétron aquoso; } \\ \mathrm{H} \bullet & \text { átomo de hidrogênio; } \\ \mathrm{H}_{2} & \text { hidrogênio molecular; } \\ \mathrm{H}_{2} \mathrm{O}_{2} & \text { peróxido de hidrogênio; } \\ \mathrm{H}_{3} \mathrm{O}^{+} & \text {próton hidratado }\end{array}$

Enquanto $\mathrm{OH} \bullet, e^{-}$aq. e $\mathrm{H} \cdot$ são espécies intermediárias reativas, o hidrogênio molecular e o peróxido de hidrogênio são produtos finais estáveis da radiólise da água. De acordo as reações:

$$
\begin{aligned}
& \mathrm{H}_{2} \mathrm{O}_{2}+\mathrm{e}^{-} \mathrm{aq} \rightarrow \mathrm{OH} \bullet+\mathrm{OH}^{-} \\
& \mathrm{H}_{2}+\mathrm{OH} \bullet \rightarrow \mathrm{H}_{2} \mathrm{O}+\mathrm{H} \bullet
\end{aligned}
$$

o hidrogênio e o peróxido de hidrogênio são amplamente consumidos. Assim, eles estão em pequena quantidade, mesmo a altas doses de radiação. Por esse motivo é que se utilizam piscinas com água para blindagem de radiação de fontes gama (DIEHL, 1990).

A formação de peróxido de hidrogênio, reconhecidamente um agente oxidante, pode não ter grande importância em alimentos irradiados. De fato tem 
menos importância que as espécies reativas intermediárias. O radical hidroxila é um poderoso agente oxidante, enquanto o elétron aquoso é forte agente redutor. $O$ átomo de hidrogênio é um agente redutor um pouco menos efetivo. Já que todos os alimentos possuem substâncias que podem ser oxidadas ou reduzidas, estas reações são esperadas quando alimentos contendo água são irradiados (DIEHL, 1990).

Um fator importante na radiólise é a presença ou não de oxigênio durante a irradiação. O oxigênio pode facilitar a formação e aumentar a quantidade de espécies reativas no meio (DIEHL, 1990).

\subsection{Reologia e viscosidade}

O termo reologia foi primeiramente introduzido por Bingham e refere-se ao estudo da deformação e do fluxo de materiais nas formas líquida, fundida ou sólida, em termos de elasticidade, viscosidade e plasticidade do material. Esta definição foi aceita quando da fundação da Sociedade Americana de Reologia em 1929 (CAMPOS, 1989). Ou seja, a Reologia é à parte da Fisica que investiga as propriedades e o comportamento mecânico dos corpos deformáveis que não são nem sólidos nem líquidos. Estuda a relação entre a deformação do fluído devido à força nele aplicada (CAMPOS, 1989; FERREIRA, 1986).

As relações reológicas ajudam-nos a entender os fluidos com que estamos trabalhando, de forma que possamos ao mesmo tempo saber como se comportam, ou forçá-los a se comportar conforme as nossas necessidades (HOWARD, 1991).

O termo viscosidade é derivado do latim viscum, significando pegajoso, portanto a viscosidade pode ser definida como grau de adesividade (JENKINS et al., 1978).

A viscosidade é o principal parâmetro que caracteriza as propriedades de fluxo de fluidos como líquidos, semi-sólidos, gases, e mesmo sólidos 
(HOWARD, 1991). Ela pode ser definida como a medida de friç̧ão interna de um fluído, ou a sua tendência em resistir ao fluxo (escoamento). Esta fricção torna-se aparente quando uma camada do fluído é forçada a mover-se em relação à outra camada. Com o aumento da friç̧ão, aumenta a força necessária para causar esse movimento, que é chamada de cisalhamento (CAMPOS, 1989; HOWARD, 1991).

No processamento de alimentos, o interesse principal está voltado para os coeficientes de transferência de calor, perda de carga em tubulações, taxa de evaporação, etc. que são estudados na área da engenharia. Contudo a reologia também tem aplicação prática no controle de qualidade dos produtos alimentícios (CAMPOS, 1989).

Dentro da definição de fluido estão incluídas substâncias tão diferentes quanto água, ar e líquidos pastosos. Porém a propriedade que caracteriza fundamentalmente um fluido é que ele apresenta uma capacidade de deformação contínua quando submetido a uma força tangencial (tensão de cisalhamento) (CAMPOS, 1989).

As caracteristicas de viscosidade ou consistência de um produto podem determinar sua aceitação ou não por parte do consumidor. Assim, um ketchup que se apresentar muito fluído (consistência baixa) pode induzir a consideração de um produto adulterado e, de outra forma, um produto muito consistente pode se tornar indesejável, dada à dificuldade em retirá-lo do frasco. Nessa mesma linha de considerações temos geléias de baixa consistência, que "umedeceriam" a bolacha ou 0 pão, tornando-os possuidores de textura desagradável, ou muito consistente, dificultando o espalhamento. A gelatina deve manter sua forma e não se deformar, perdendo suas características. Todos esses exemplos demonstram a importância da viscosidade nos alimentos (CAMPOS, 1989).

Os parâmetros reológicos são muito utilizados em diferentes campos da ciência de alimentos (CAMPOS, 1989). JENKINS et al. (1978) estudaram a influência da viscosidade de goma guar, pectina, carragenana, metilcelulose, e outras fibras alimentícias na absorção de glicose pelo organismo. 
Os dados de viscosidade freqüentemente funcionam como uma "janela" através dos quais outras características do material podem ser observadas: A viscosidade é mais facilmente medida que algumas outras propriedades que afetam o material, tornando-a uma, ferramenta valiosa para sua caracterização (BROOKFIELD ENGENEERING LABORATORIES, s.d.).

Os alimentos são materiais estruturalmente e reológicamente complexos. Muitas vezes eles consistem de uma mistura de sólidos e componentes fluídos estruturais como, por exemplo, material sólido proveniente de paredes celulares, água, líquidos coloidais e gases intercelulares. Muitos alimentos ainda apresentam caracteristicas que variam de um ponto a outro dentro de sua massa. Apesar desses fatores, vários pesquisadores tem observado que os alimentos se comportam de uma maneira previsivel e conceitos baseados nas teorias de elasticidade, plasticidade e viscosidade podem ser usados para interpretar suas respostas a forças a eles aplicadas (CAMPOS, 1989).

A temperatura é um dos fatores mais óbvios que tem um efeito nas propriedades reológicas dos materiais. Alguns materiais são muito sensiveis à temperatura, e variações pequenas resultam numa mudança significante na viscosidade, outros são relativamente insensiveis (BROOKFIELD ENGENEERING LABORATORIES, s.d.).

Quando o comportamento de um determinado fluido apresenta uma relação linear entre taxa de deformação e tensão de cisalhamento, ou seja, a viscosidade é constante, ele é chamado de Newtoniano, sendo a equação (5) conhecida como Lei de Newton da viscosidade (BIRD et al.,1965, VAN WAZER et al., 1963) 


$$
\frac{F}{A}=-\mu\left(\frac{d V_{x}}{d y}\right)
$$

Onde $F / A=\tau$ é à força de cisalhamento, $\mu$ é o coeficiente de viscosidade $e d V x / d y=\gamma$ é o gradiente de velocidade ou taxa de cisalhamento. $A$ unidade de medida de $\mu$ é o "poise", definido como a resistência oferecida por um material que requer uma força de uma dina por $\mathrm{cm}^{2}$ de área para produzir uma taxa de cisalhamento igual ao inverso de um segundo.

Portanto os fluidos Newtonianos têm um comportamento caracteristico, onde a viscosidade não depende da taxa de cisalhamento numa dada temperatura (HOWARD, 1991). Em outras palavras, duplicando-se a força moveríamos o fluídos duas vezes mais rápido. Essa suposição é ideal, mas raramente encontrada e é correta somente em parte. Na realidade para os reologistas, a maioria dos materiais, exibe um complexo comportamento nãoNewtoniano (JENKINS, et al., 1978). Um fluído Newtoniano terá uma viscosidade constante com taxas de cisalhamento variáveis, independente do modelo de viscosímetro, spindle, ou velocidade usada.

Exemplos de fluidos Newtonianos são os óleos silicone, vários xaropes, frutose em água, vinho, óleos minerais, álcoois e água (BROOKFIELD ENGENEERING LABORATORIES, s.d.).

Por outro lado nos fluídos chamados de não-Newtonianos, a taxa de cisalhamento e tensão de cisalhamento não são constantes, dependendo ainda do tempo de observação ou de forças de recuperação elástica.

A viscosidade de materiais não-Newtonianos é dependente da taxa de cisalhamento na qual ele é medido (HOWARD, 1991). Para esses fluidos por analogia com a equação (5) é definida uma viscosidade aparente $\left(\mu_{\mathrm{a}}\right)$, segundo a equação (CAMPOS, 1989): 


$$
u_{,}-\frac{\tau_{y x}}{\frac{d V_{x}}{d_{y}}}
$$

Conforme enfatizado acima $\mu_{a}$ não será uma constante e sua magnitude poderá variar em função de outros fatores. Consequentemente, os valores de $\mu_{\mathrm{a}}$ obtidos em determinadas condições de ensaio não deverão ser extrapolados para utilização em outras situações (CAMPOS, 1989).

Os fluidos não-newtonianos podem ser classificados em três grandes grupos: dependentes $\mathrm{e}$ independentes do tempo e fluidos que apresentam recuperação elástica. Em sistemas independentes do tempo, a viscosidade muda com a mudança da taxa de cisalhamento. Entretanto, a qualquer taxa de cisalhamento dada, a viscosidade vai ter um valor definido em função do tempo. Em sistemas dependentes do tempo, a viscosidade muda com o tempo sob uma taxa de cisalhamento constante (CAMPOS, 1989).

Abaixo o esquema mostra a classificação dos fluidos não Newtonianos (CAMPOS, 1989).

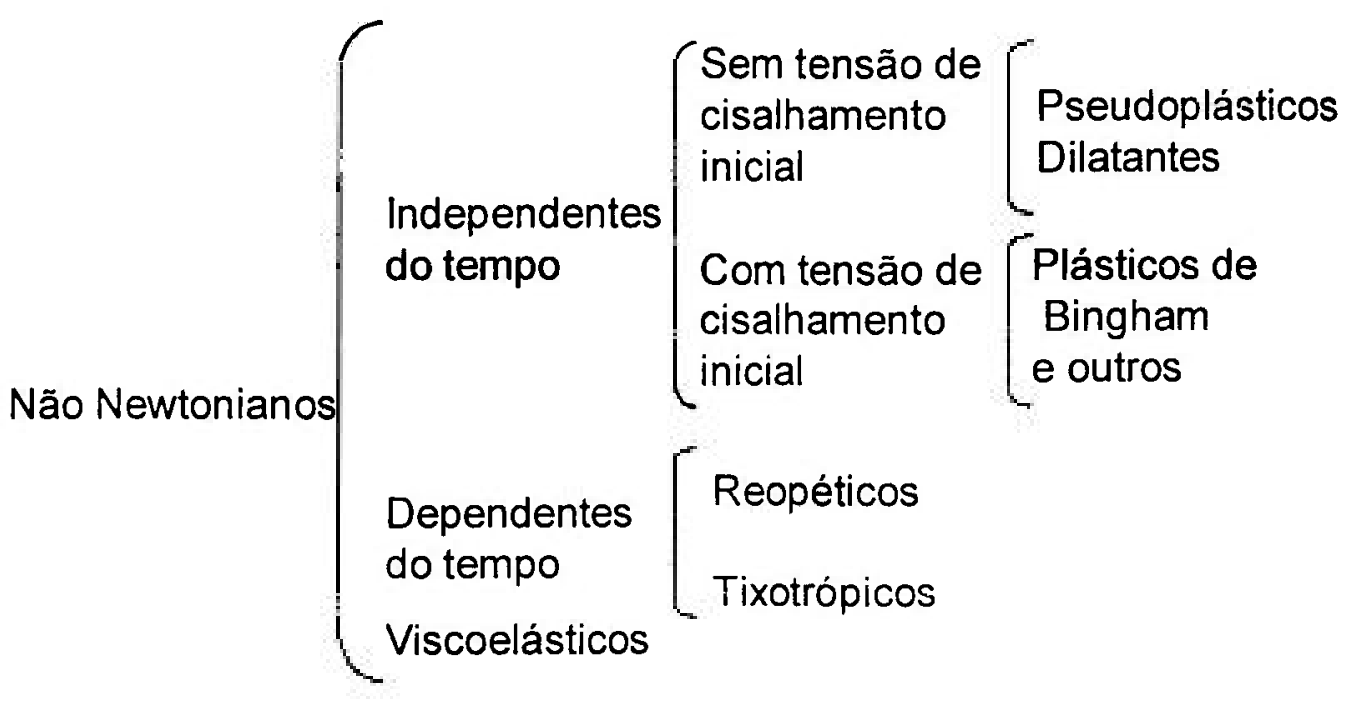


Para medir a viscosidade de um fluido a uma determinada temperatura, é necessário considerar as dimensões da amostra, as forças geradas na deformação da amostra e a velocidade ou taxa de cisalhamento. Muitos viscosimetros têm sensores de temperatura incorporados e determinam automaticamente a viscosidade a partir da taxa de deformação gerada (ALISTE, 1999)

Os viscosímetros concêntricos rotacionais são geralmente os mais utilizados na medida da viscosidade dos fluídos não-Newtonianos. Eles medem o torque necessário para rotacionar uma haste metálica cilíndrica (o spindle) que é imersa no fluído. O spindle é acionado por um motor sincronizado por meio de uma mola calibrada que the permite uma taxa de cisalhamento especifica; a resistência do fluxo (viscosidade) é indicada pela deflexão da mola, que é proporcional a velocidade de rotação do spindle, tamanho e forma geométrica (ALISTE, 1999).

\subsection{Legislação de alimentos irradiados}

Com o Decreto-Lei $n^{\circ} .73 .718$ de 29 de agosto de 1973 se estabeleceram no Pais as normas gerais sobre irradiação de alimentos. Nessas normas gerais, os requisitos gerais do processo são: "Qualquer alimento poderá ser tratado por radiação desde que sejam observadas as seguintes condições:

a) A dose absorvida minima deve ser suficiente para alcançar a finalidade pretendida;

b) A dose absorvida máxima deve ser inferior àquela que comprometeria as propriedades funcionais e ou os atributos sensoriais do alimento (BRASIL, 2001)".

A Resolução - RDC n. 21, de 26 de Janeiro de 2001, revoga as Portarias n. 09 DINAL/MS de 08 de Março de 1985 e n. 30 de 25 de Setembro de 1989 (BRASIL, 1985; BRASIL, 1989), as quais estabeleciam listas de produtos 
que podiam ser irradiados e limitava o valor das doses a serem utilizadas. Assim, - Brasil conta hoje com uma legislação extremamente abrangente e genérica, 0 que visa permitir uma ampla gama de possibilidades de aplicação comercial da técnica.

\section{MATERIAL E MÉTODOS}

\subsection{Material}

\subsubsection{Agarana, Carragenana e Alginato de sódio}

Foram utilizadas a K-carragenana e agarana da Agar Brasileiro Ltda. Utilizou-se o alginato de sódio da Sigma-Aldrich (CAS n. 18,094-4).

As soluções foram preparadas diluindo-se os hidrocolóides a quente $\left( \pm 100^{\circ} \mathrm{C}\right)$, e acrescentando-os até se obter soluções a $1 \% \mathrm{p} / \mathrm{v}$.

\subsection{2 Ácido ascórbico}

O ácido ascórbico em pó utilizado foi adquirido da empresa Orion Ltda. Adicionou-se o ácido ascórbico às soluções dos hidrocolóides até se atingir as concentrações de: 0,0mM; 57,0mM; $85,5 \mathrm{mM} ; 114,0 \mathrm{mM}$ e $142,5 \mathrm{mM}$.

\subsubsection{Rosela}

O extrato de rosela (Hibiscus sabdariffa) foi obtido de cálices secos. A extração foi realizada fazendo-se uma infusão dos cálices secos em água a $5 \%$ $\mathrm{p} / \mathrm{v}$. Esse extrato assim obtido foi adicionado às soluções dos hidrocolóides previamente preparadas até se atingir as concentrações de: $0 \%, 10 \%, 20 \%, 30 \%$ e $40 \% \mathrm{v} / \mathrm{v}$. 


\subsubsection{Isoflavona}

A isoflavona de soja utilizada foi adquirida no mercado, da marca Gynoflavona (extrato concentrado de soja rico em agliconas-genisteína). Às soluções de hidrocolóides previamente preparadas acrescentou-se a isoflavona de soja suficiente para se obter concentrações de: $0,0 \mathrm{~g} \cdot \mathrm{L}^{-1}, 0,5 \mathrm{~g} \cdot \mathrm{L}^{-1}, 1 \mathrm{~g} \cdot \mathrm{L}^{-1}$, $1,5 \mathrm{~g} \cdot \mathrm{L}^{-1}, 2 \mathrm{~g} \cdot \mathrm{L}^{-1}$.

\subsection{Métodos}

\subsubsection{Irradiações}

As soluções contendo os hidrocolóides e os antioxidantes, foram irradiadas em frascos de vidro de $100 \mathrm{~mL}$ numa fonte de ${ }^{60} \mathrm{Co}$ Gammacell 220 (AECL), com uma taxa de dose de aproximadamente $5 \mathrm{kG} / \mathrm{h}$, nas seguintes doses: 0,$0 ; 1,0 ; 2,5 ; 5,0 ; 7,5$ e $10 \mathrm{kGy}$. A dosimetria da fonte fora feita previamente utilizando dosimetros de Fricke. A taxa de uniformidade de dose foi de 1,13.

\subsubsection{Viscosimetria}

Foram aplicadas as técnicas viscosimétricas desenvolvidas previamente no laboratório (ALISTE, 1999), utilizando viscosímetro Brookfield, modelo LV-DVIII, com adaptador ULA (ultra low adaptador) e o spindle SC4-18, com banho termostatizado Neslab modelo RTE-210, precisão $\pm 0,1^{\circ} \mathrm{C}$. As diluições a $1,0 \% \mathrm{p} / \mathrm{v}$ dos hidrocolóides a serem irradiados foram preparadas mediante aquecimento até dissolução. O viscosimetro acoplado a um software Rheocalc VI.1, fornece para cada valor de velocidade do spindle, a viscosidade aparente, a força e a taxa de cisalhamento para cada valor da temperatura. $A$ irradiação das soluções foi realizada imediatamente após o preparo das soluções. As leituras da viscosidade de soluções de carragenana, e agarana, com adição ou 
não dos antioxidantes foram realizadas a $60^{\circ} \mathrm{C}$. Nas soluções de alginato de sódio as temperaturas de leituras foram de $45^{\circ} \mathrm{C}$. Ressaltando que essas temperaturas de leitura da viscosidade, foram escolhidas depois de vários experimentos, como sendo as mais apropriadas para cada caso.

\subsubsection{Medidas de $\mathrm{pH}$}

Todas as medidas de $\mathrm{pH}$ foram realizadas com um medidor de $\mathrm{pH}$ marca Analyser, modelo 300 a $25^{\circ} \mathrm{C}$.

\subsubsection{Análise Estatística}

O método utilizado para a análise estatística foi a da distribuição $t$ de Student, que é empregada no caso de pequeno número de amostras ( $n \leq 30)$. Lembrando que o valor de 0,68 é utilizado como parâmetro de comparação entre valores estatísticos, é a chamada regra empirica. É válido somente para dados com distribuição aproximadamente em forma de sino. Neste caso a média e o desvio-padrão estão relacionados com a proporção de dados que se enquadram em determinados limites. Para distribuições em forma de sino:

- cerca de $68 \%$ de todos os valores estão a menos de um desviopadrão da média.

- cerca de $95 \%$ de todos os valores estão a menos de dois desviopadrão da média.

- cerca de $99,7 \%$ de todos os valores estão a menos de três desviopadrão da média (TRIOLA, 1999; SPIEGEL, 1993).

Para realização dos cálculos utilizou-se o programa Microsoft Office Excel. 


\section{RESULTADOS}

\subsection{Agarana, carragenana e alginato de sódio.}

A taxa de cisalhamento de $330 \mathrm{~s}^{-1}$, na qual foram obtidas as medidas de viscosidade, foi escolhida após vários ensaios, levando-se em conta as limitações experimentais de aplicação do viscosimetro. Nessa taxa foi possivel realizar a leitura da viscosidade de todas as soluções dos hidrocolóides utilizados, acrescidas ou não de antioxidantes, submetidas ou não à irradiação.

Com relação à temperatura utilizou-se um valor que também possibilitasse a leitura da viscosidade de todas as soluções, de forma que não ocorre-se a gelificação e também que o valor de viscosidade ficasse na faixa de leitura do viscosímetro.

Na Figura 13 apresenta-se a variação da viscosidade das soluções aquosas dos três hidrocolóides estudados em função da dose, sem adição de antioxidantes. Os valores de viscosidade obtidos são a média de três leituras de três experimentos independentes. 


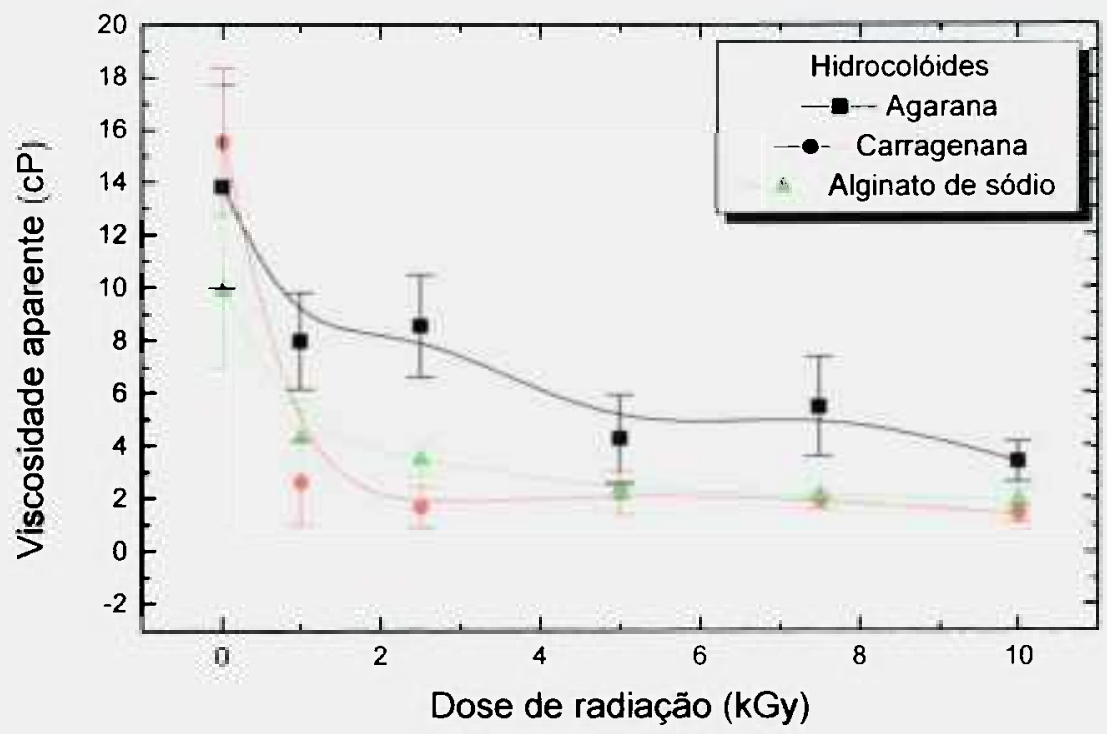

Figura 13 - Viscosidade em função da dose das soluções de agarana, carragenana e alginato de sódio, a taxa de cisalhamento de $330 \mathrm{~s}^{-1} \mathrm{e}$ $60^{\circ} \mathrm{C}$.

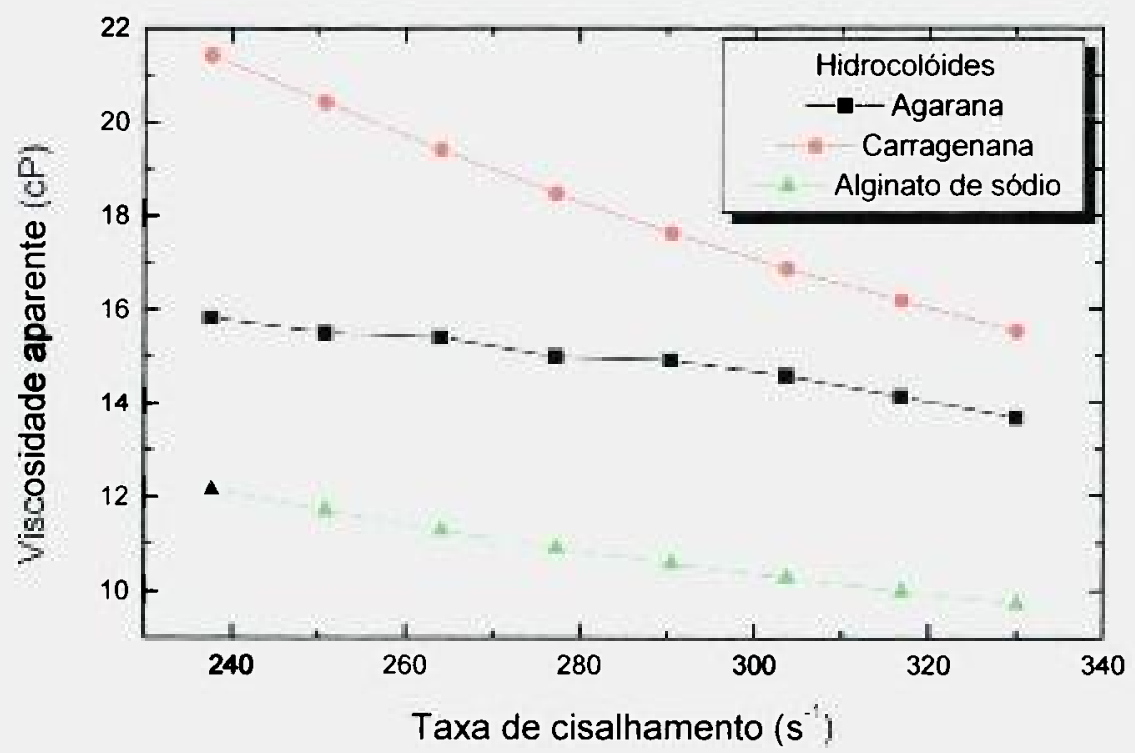

Figura 14 - Viscosidade em função da taxa de cisalhamento das soluçōes de agarana, carragenana e alginato de sódio, a OkGy e $60^{\circ} \mathrm{C}$. 
$\mathrm{Na}$ Figura 14 é apresentada a viscosidade em função da taxa de cisalhamento para os três polissacarídeos que são objeto deste estudo. É possivel observar a diminuição da viscosidade com o aumento da taxa de cisalhamento, o que caracteriza um comportamento pseudoplástico, não Newtoniano, particularmente no caso da carragenana.

Para as soluções dos hidrocolóides acrescidas de ácido ascórbico, extrato de rosela e isoflavona de soja os dados são apresentados segundo obtidos e também normalizados em relação aos respectivos valores sem irradiar, para melhor visualização do efeito que esses aditivos exerceram sobre os respectivos sistemas. Os dados diretos da leitura do viscosimetro constam no apêndice.

\section{2 Ácido ascórbico}

O próprio ácido ascórbico induz uma drástica redução da viscosidade das soluções de agarana quando adicionado às soluções dos hidrogéis, com um valor de redução perto de $80 \%$ quando a concentração do ácido foi de $57 \mathrm{mM}$ e $85,5 \mathrm{mM}$. As Figuras $15 \mathrm{a}$ e $15 \mathrm{~b}$ apresentam a variação da viscosidade em função da dose para as várias concentrações de ácido ascórbico. É possivel perceber que, na presença deste, há um aumento da viscosidade do hidrocoloide, o que poderia ser interpretado como uma ação radioprotetora do ácido ascórbico, mas que é dependente da sua concentração. Essa ação aparece mais pronunciada para valores de concentrações de $57 \mathrm{mM}$ e $85,5 \mathrm{mM}$. 


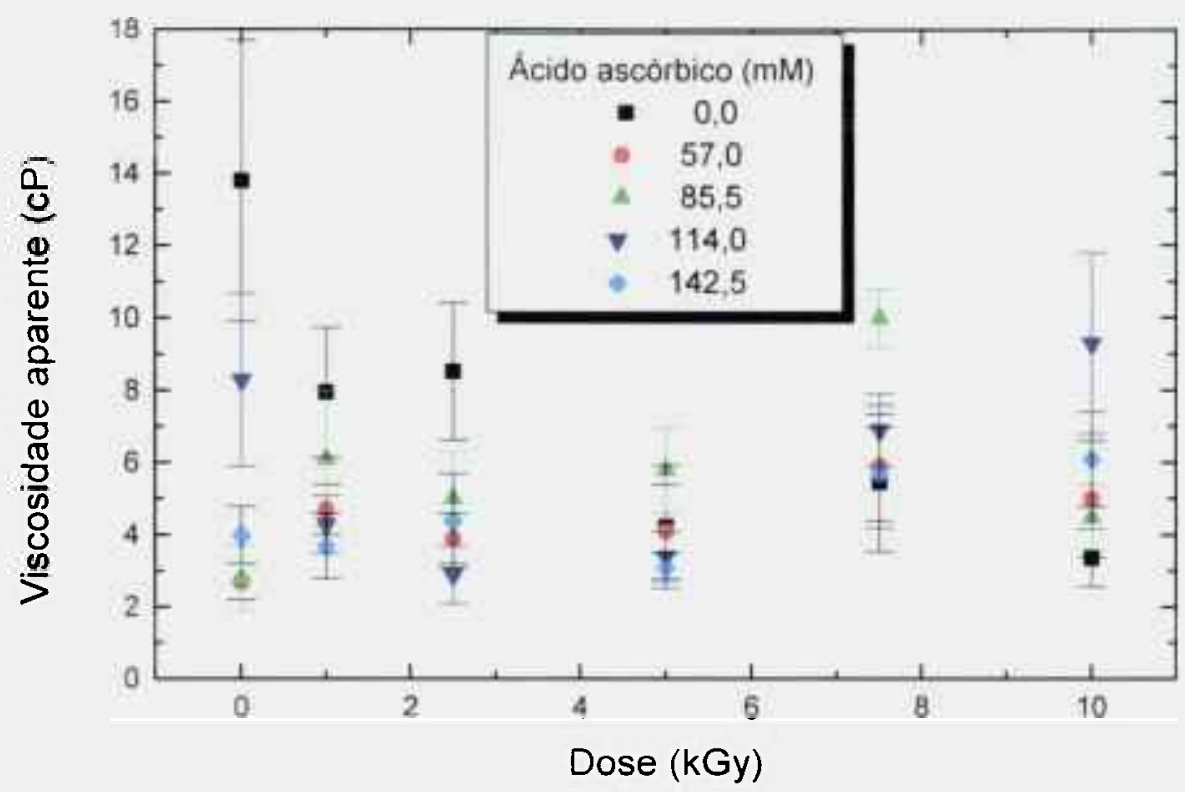

Figura $15 a$ - Viscosidade em função da dose, das soluções de agarana na presença de diferentes concentrações de ácido ascórbico, à taxa de cisalhamento de $330 \mathrm{~s}^{-1}$ e $60^{\circ} \mathrm{C}$.

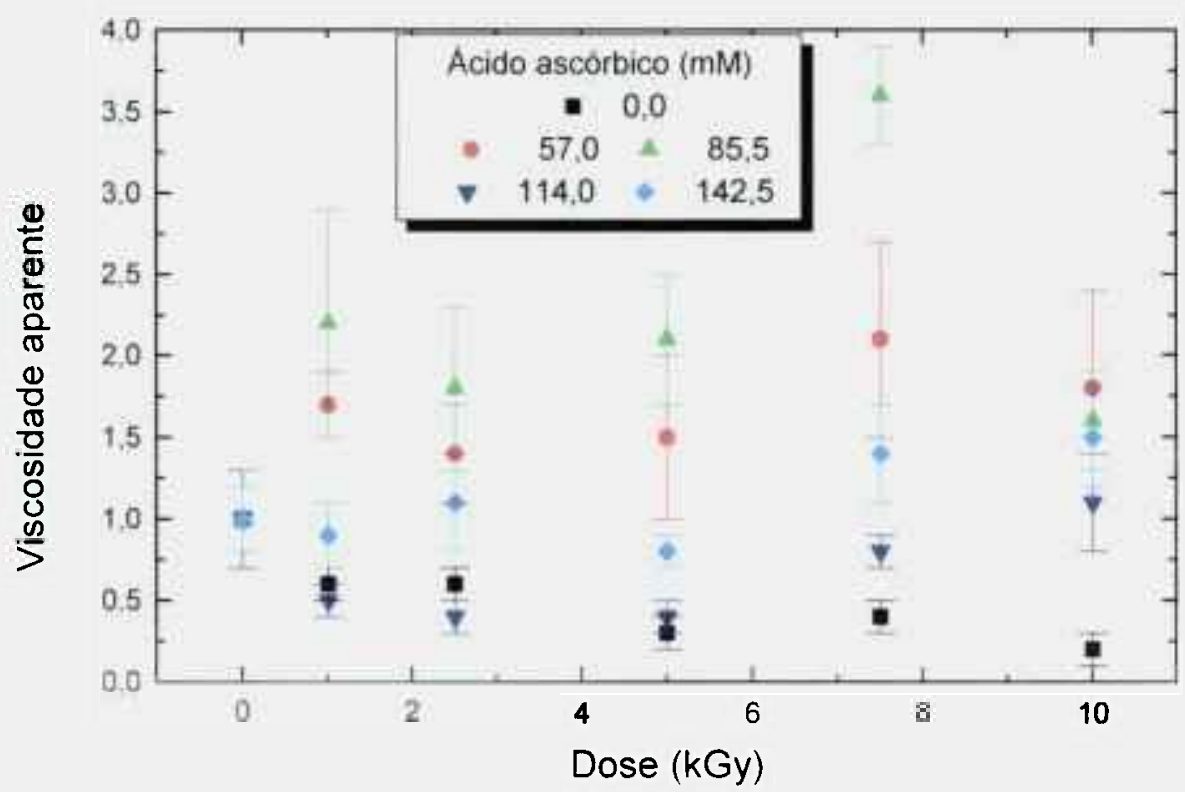

Figura 15b - Viscosidade em função da dose, das soluções de agarana na presença de diferentes concentrações de ácido ascórbico, à taxa de cisalhamento de $330 \mathrm{~s}^{-1}$ e $60^{\circ} \mathrm{C}$ (dados normalizados). 
$\mathrm{O}$ pH das soluções de agarana, para uma mesma concentração de ácido ascórbico permanece praticamente inalterado (Tabela 3), isto é, a radiação per se não induz modificações no $\mathrm{pH}$. Mas houve um aparente aumento do $\mathrm{pH}$ em função da dose nas soluções sem adição do ácido.

Tabela 3 - Medidas do pH das soluções de agarana em função da dose e da concentração de ácido ascórbico.

\begin{tabular}{cccccc}
\hline \multirow{2}{*}{ Dose (kGy) } & \multicolumn{5}{c}{ Concentração de ácido ascórbico (mM) } \\
\cline { 2 - 6 } & 0,0 & 57,0 & 85,5 & 114,0 & 142,5 \\
\hline 0,0 & 5,5 & 2,6 & 2,5 & 2,6 & 2,5 \\
1,0 & 5,6 & 2,6 & 2,6 & 2,4 & 2,5 \\
2,5 & 5,2 & 2,6 & 2,6 & 2,5 & 2,6 \\
5,0 & 4,5 & 2,6 & 2,6 & 2,6 & 2,6 \\
7,5 & 4,1 & 2,6 & 2,5 & 2,6 & 2,5 \\
10,0 & 4,1 & 2,6 & 2,6 & 2,6 & 2,6 \\
\hline
\end{tabular}

No caso das soluções de carragenana houve também uma grande redução da viscosidade produzida pelo acréscimo do ácido. Entretanto, não houve, em todas as concentrações de ácido ascórbico, decréscimo da viscosidade com o aumento da dose (Figuras 16a, 16b). $\mathrm{O}$ pH permaneceu estável para uma mesma concentração de ácido ascórbico (Tabela 4), embora tenha havido um aparente decréscimo do pH em função da dose para as soluções de carragenana sem antioxidante. 


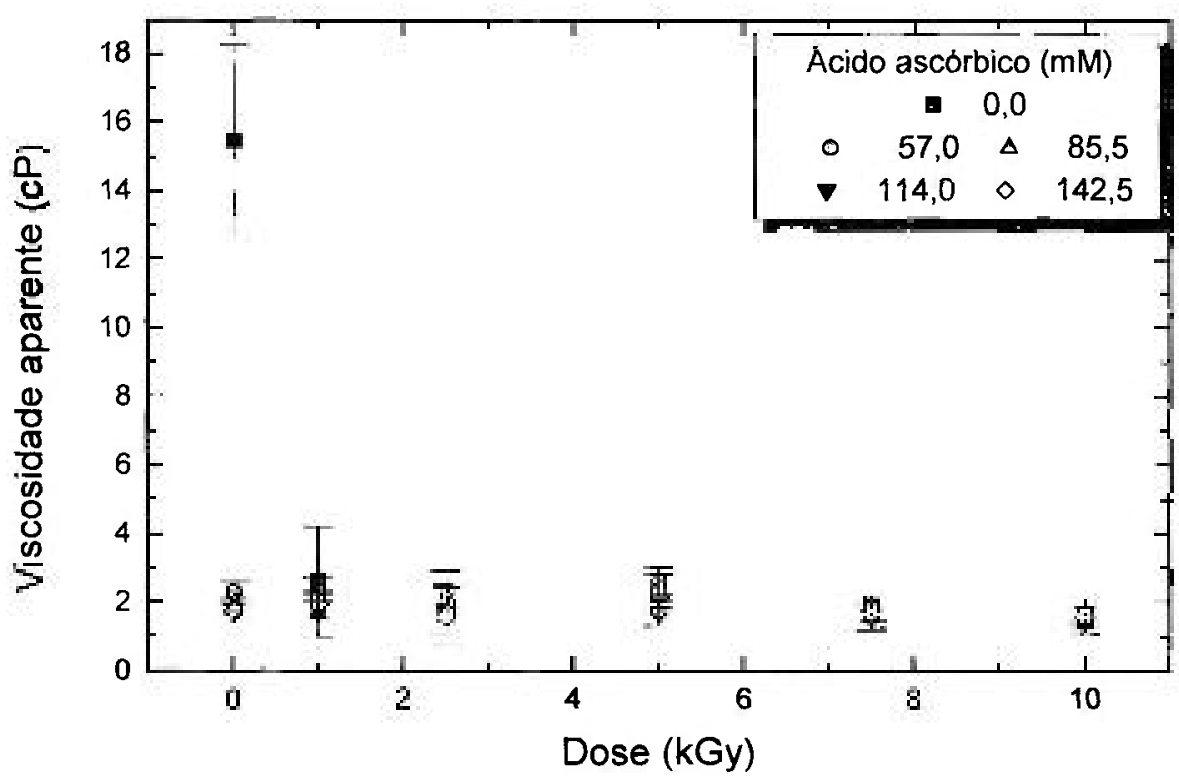

Figura 16a - Viscosidade em função da dose, das soluções de carragenana na presença de diferentes concentrações de ácido ascórbico, à taxa de cisalhamento de $330 \mathrm{~s}^{-1}$ e $60^{\circ} \mathrm{C}$.

Tabela 4 - Medidas do pH das soluções de carragenana em função da dose e da concentração de ácido ascórbico.

\begin{tabular}{cccccc}
\hline \multirow{2}{*}{ Dose (kGy) } & \multicolumn{5}{c}{ Concentração de ácido ascórbico $(\overline{\mathrm{Mm}})$} \\
\cline { 2 - 6 } & 0,0 & 57,0 & 85,5 & 114,0 & 142,5 \\
\hline 0,0 & 6,1 & 3,1 & 2,7 & 2,7 & 2,8 \\
1,0 & 5,6 & 2,9 & 2,8 & 2,7 & 2,7 \\
2,5 & 5,3 & 2,9 & 2,9 & 2,7 & 2,7 \\
5,0 & 4,5 & 2,7 & 2,6 & 2,4 & 2,3 \\
7,5 & 3,9 & 2,6 & 2,4 & 2,3 & 2,3 \\
10,0 & 3,8 & 2,8 & 2,6 & 2,6 & 2,7 \\
\hline
\end{tabular}




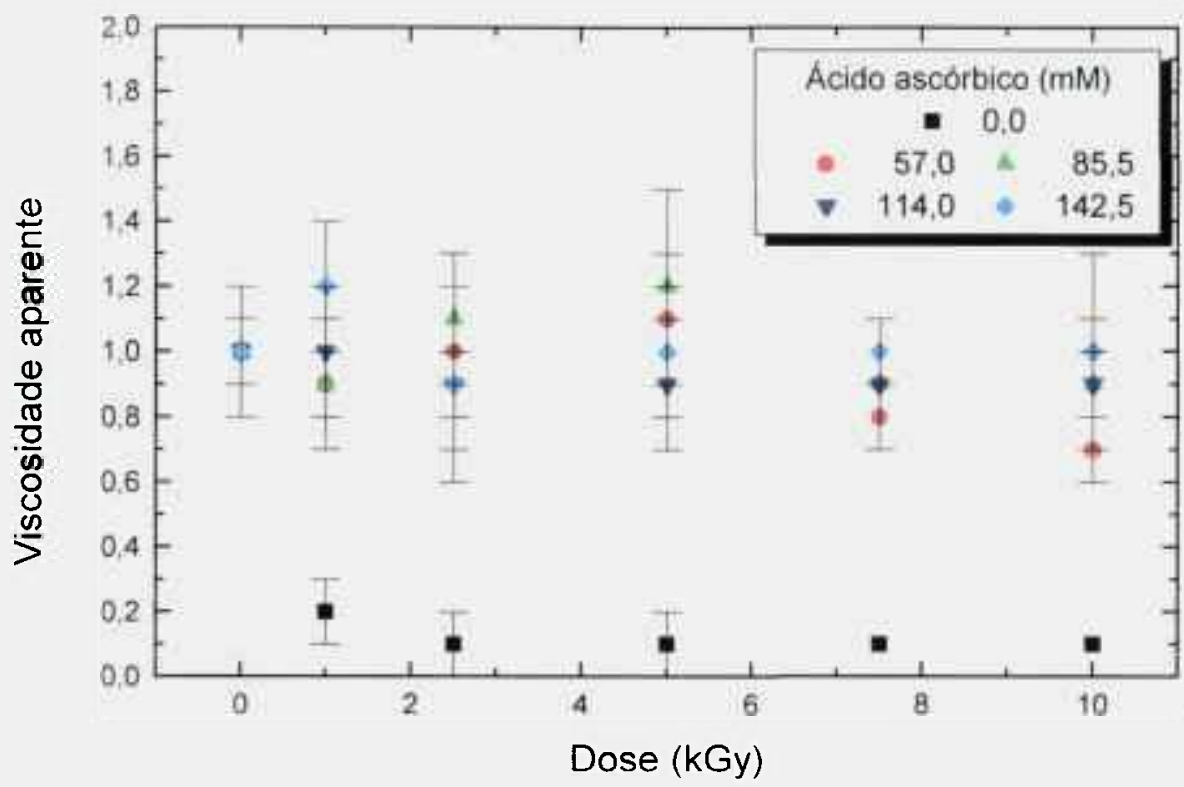

Figura 16b - Viscosidade em função da dose, das soluções de carragenana na presença de diferentes concentrações de ácido ascórbico, à taxa de cisalhamento de $330 \mathrm{~s}^{-1}$ e $60^{\circ} \mathrm{C}$ (dados normalizados).

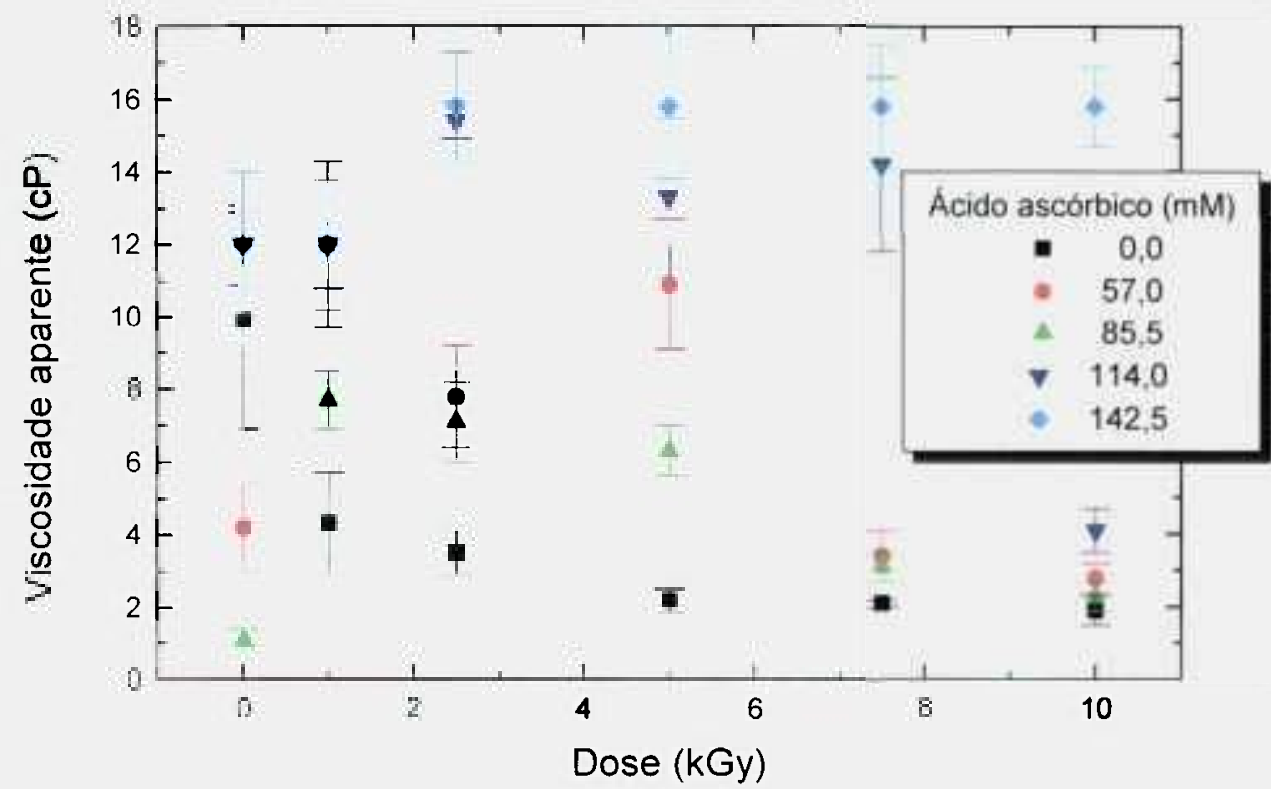

Figura 17a - Viscosidade em função da dose, das soluções de alginato de sódio na presença de diferentes concentrações de ácido ascórbico à taxa de cisalhamento de $330 \mathrm{~s}^{-1}$ e $45^{\circ} \mathrm{C}$. 
Nas Figuras 17a e 17b são mostradas as variações da viscosidade das soluções de alginato de sódio adicionadas ou não de ácido ascórbico. Neste caso também há uma importante influência da adição do ácido, mas agindo diferentemente. Para as maiores concentrações, $114,0 \mathrm{mM}$ e $142,5 \mathrm{mM}$, o ácido ascórbico aumentou a viscosidade das soluções mesmo antes da irradiação. Entretanto, para os valores de $57,0 \mathrm{mM}$ e $85,5 \mathrm{mM}$ o comportamento foi similar aos apresentados pelos polissacarideos agarana e carragenana. De toda forma, seria compatível com um comportamento radioprotetor do ácido ascórbico nessas concentrações agindo sobre soluções de alginato.

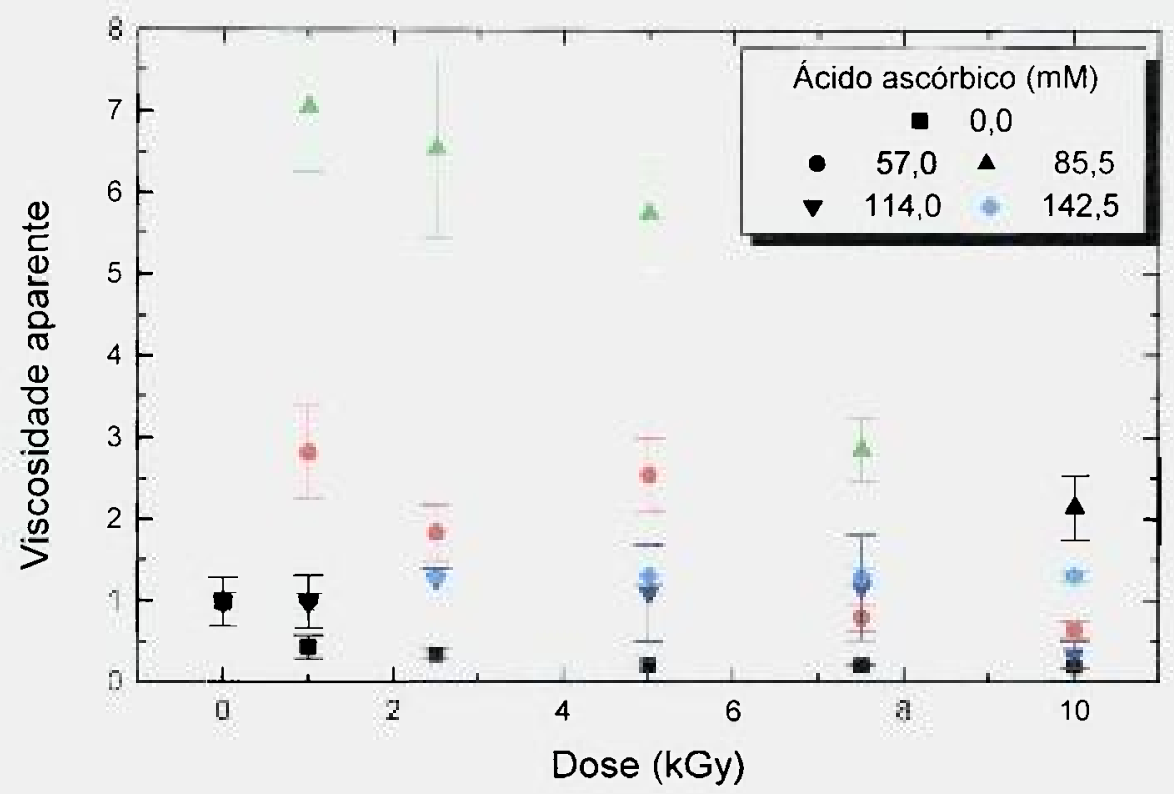

Figura 17b - Viscosidade em função da dose, das soluções de alginato de sódio na presença de diferentes concentrações de ácido ascórbico à taxa de cisalhamento de $330 \mathrm{~s}^{-1}$ e $45^{\circ} \mathrm{C}$ (dados normalizados). 
Tabela 5 - Medidas do pH das soluções de alginato de sódio em função da dose e da concentração de ácido ascórbico.

\begin{tabular}{cccccc}
\hline \multirow{2}{*}{ Dose (kGy) } & \multicolumn{5}{c}{ Concentração de ácido ascórbico (mM) } \\
\cline { 2 - 6 } & 0,0 & 57,0 & 85,5 & 114,0 & 142,5 \\
\hline 0,0 & 7,0 & 3,8 & 3,6 & 3,5 & 3,4 \\
1,0 & 6,5 & 3,8 & 3,6 & 3,5 & 3,5 \\
2,5 & 6,5 & 3,8 & 3,5 & 3,4 & 3,5 \\
5,0 & 7,1 & 3,9 & 3,7 & 3,5 & 3,4 \\
7,5 & 7,2 & 3,7 & 3,4 & 3,4 & 3,5 \\
10,0 & 6,3 & 3,5 & 3,3 & 3,5 & 3,3 \\
\hline
\end{tabular}

O comportamento do $\mathrm{pH}$ segue os casos anteriores, seu valor para soluções de alginato de sódio com uma mesma concentração de ácido ascórbico e doses diferentes de radiação, permaneceu praticamente inalterado (Tabela 5).

Na Tabela 6 estão os valores estatísticos calculados pelo método $t$ de Student, para as soluções dos três hidrocolóides utilizados. Sem adição de ácido ascórbico, a probabilidade do valor da viscosidade de agarana sem irradiar ser igual a da viscosidade de agarana irradiada é de 0,22 , ou seja são diferentes estatisticamente. Há influência da radiação na viscosidade da agarana. Para a concentração de $57,0 \mathrm{mM}$, a probabilidade $(P)$ de serem iguais é de 0,98 , ou seja são estatisticamente iguais. Mas para as concentrações de $85,5 \mathrm{mM}$ e $114,0 \mathrm{mM}$ há diferenças significativas, ou seja, a presença do ácido ascórbico modificou a ação da radiação no sistema.

Para carragenana o efeito da radiação sobre a solução do polissacarideo sozinho não seria significativo no global (há muita variação), mas quando o ácido ascórbico é adicionado a $57,0 \mathrm{mM}, 85,5 \mathrm{mM}, 114,0 \mathrm{mM}$ e $142,5 \mathrm{mM}$ há sim diferenças significativas.

No caso do alginato de sódio, sem ácido ascórbico o valor é 0,86 , ou seja maior que 0,68 , portanto não haveria diferença significativa. Porém, nas concentrações de $57,0 \mathrm{mM}, 114,0 \mathrm{mM}$ e $142,5 \mathrm{mM}$, os valores encontrados indicam 
que ocorreram diferenças significativas, caracterizando um comportamento radioprotetor.

Tabela 6 - Comparação da significância estatística $(P)$ das soluções de agarana, carragenana e alginato de sódio entre irradiado e não irradiado (método $t$ de Student).

\begin{tabular}{cccccc}
\hline \multirow{2}{*}{ Hidrocolóide } & \multicolumn{5}{c}{ Concentração de ácido ascórbico (mM) } \\
\cline { 2 - 6 } & 0,0 & 57,0 & 85,5 & 114,0 & 142,5 \\
\hline Agarana & 0,22 & 0,98 & 0,48 & 0,45 & 0,92 \\
Carragenana & 0,96 & 0,20 & 0,15 & 0,13 & 0,13 \\
Alginato de sódio & 0,86 & 0,29 & 0,89 & 0,01 & 0,00 \\
\hline
\end{tabular}

\subsection{Rosela}

Nas Figuras 18a e 18b, ilustra-se o comportamento das soluções de agarana, com adição de extrato de rosela, irradiadas com diferentes doses de radiação. É possivel observar uma diminuição do valor da viscosidade de agarana pela simples adição do extrato de rosela, o que torna este comportamento semelhante ao apresentado pelo ácido ascórbico. Entretanto, para os valores mais elevados de doses aplicadas, o efeito radioprotetor torna-se bem evidente. 


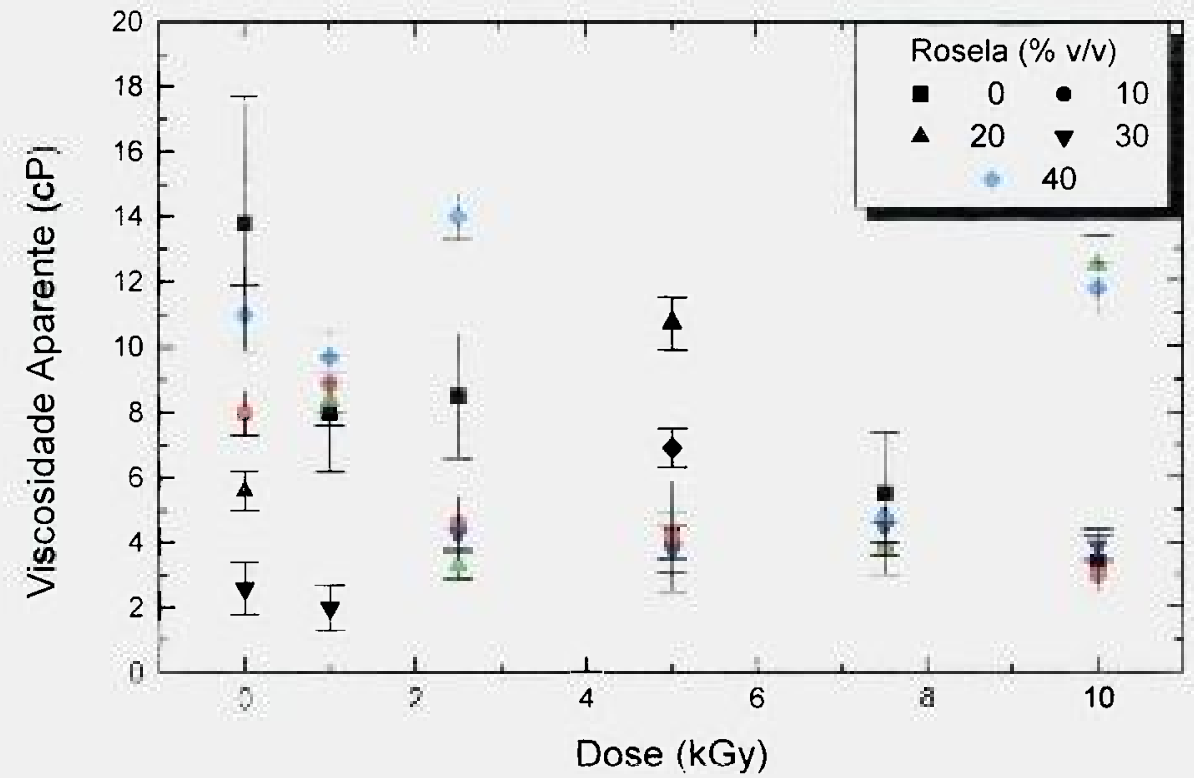

Figura 18a - Viscosidade em função da dose, das soluções de agarana, na presença de diferentes soluções de extrato de rosela, à taxa de cisalhamento de $330 \mathrm{~s}^{-1}$ e $60^{\circ} \mathrm{C}$.

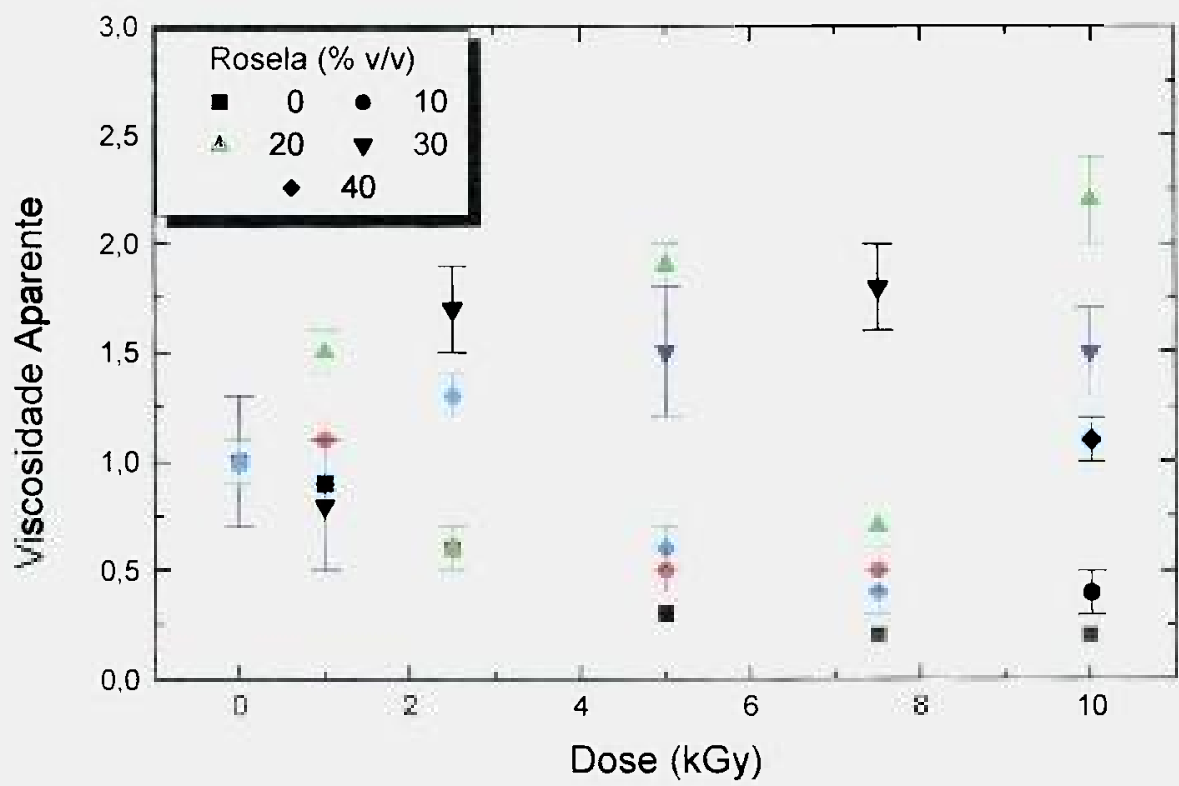

Figura 18b - Viscosidade em função da dose, das soluções de agarana, na presença de diferentes soluções de extrato de rosela, à taxa de cisalhamento de $330 \mathrm{~s}^{-1}$ e $60^{\circ} \mathrm{C}$ (dados normalizados). 
Tabela 7 - Medidas do pH das soluções de agarana em função da dose e da concentração de rosela.

\begin{tabular}{cccccc}
\hline \multirow{2}{*}{ Dose (kGy) } & \multicolumn{5}{c}{ Concentração de extrato de rosela (\% v/v) } \\
\cline { 2 - 6 } & 0,0 & 10 & 20 & 30 & 40 \\
\hline 0,0 & 5,5 & 2,8 & 2,6 & 2,6 & 2,5 \\
1,0 & 5,6 & 2,8 & 2,6 & 2,6 & 2,5 \\
2,5 & 5,2 & 2,8 & 2,7 & 2,6 & 2,5 \\
5,0 & 4,5 & 2,9 & 2,7 & 2,6 & 2,6 \\
7,5 & 4,1 & 2,9 & 2,7 & 2,6 & 2,6 \\
10,0 & 4,1 & 2,9 & 2,7 & 2,6 & 2,5 \\
\hline
\end{tabular}

Os dados apresentados na Tabela 7 evidenciam que $0 \mathrm{pH}$ das diversas soluções de agarana não varia em função da dose.

O comportamento da viscosidade das soluções de carragenana é mostrado nas Figuras 19a e 19b. Há semelhança com o comportamento induzido pelo ácido ascórbico neste mesmo polissacarídeo. $\mathrm{Na}$ Tabela 8 são apresentados os valores de $\mathrm{pH}$ das soluções de carragenana acrescidos de extrato de rosela que mostram a influência da dose. 


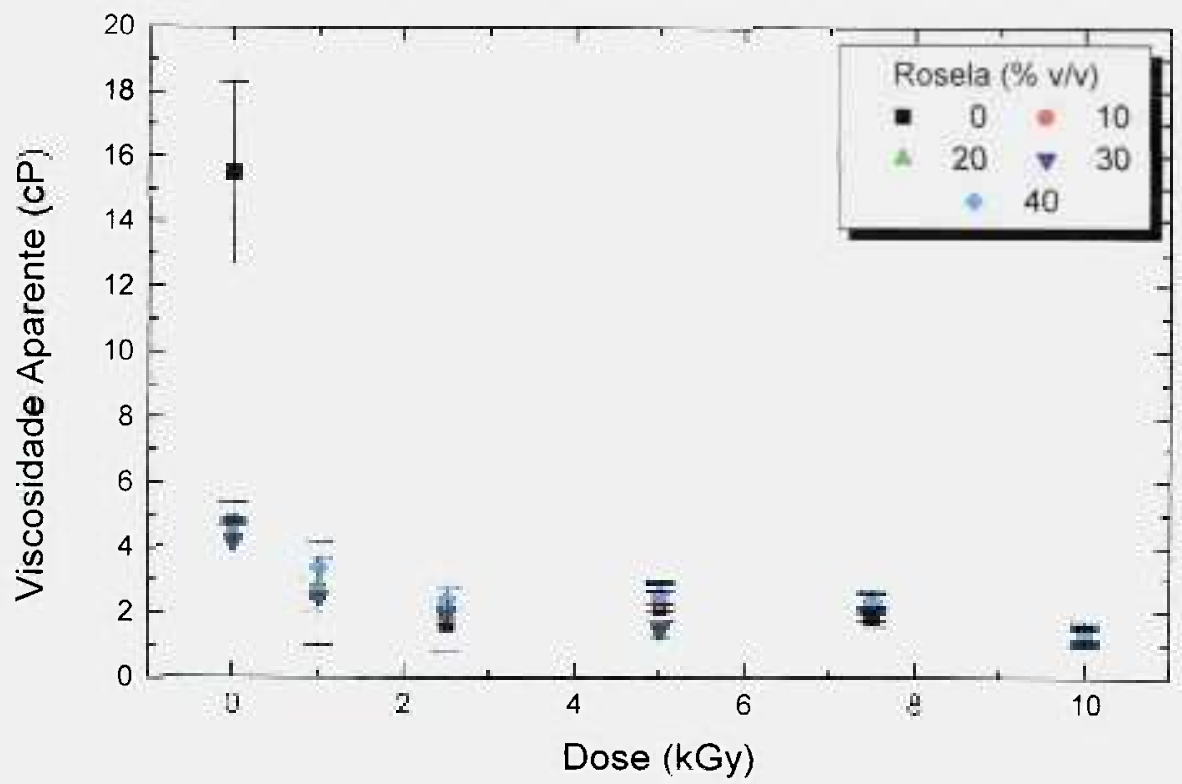

Figura 19a - Viscosidade em função da dose, das soluções de carragenana na presença de diferentes concentrações de extrato de rosela, à taxa de cisalhamento de $330 \mathrm{~s}^{-1}$ e $60^{\circ} \mathrm{C}$.

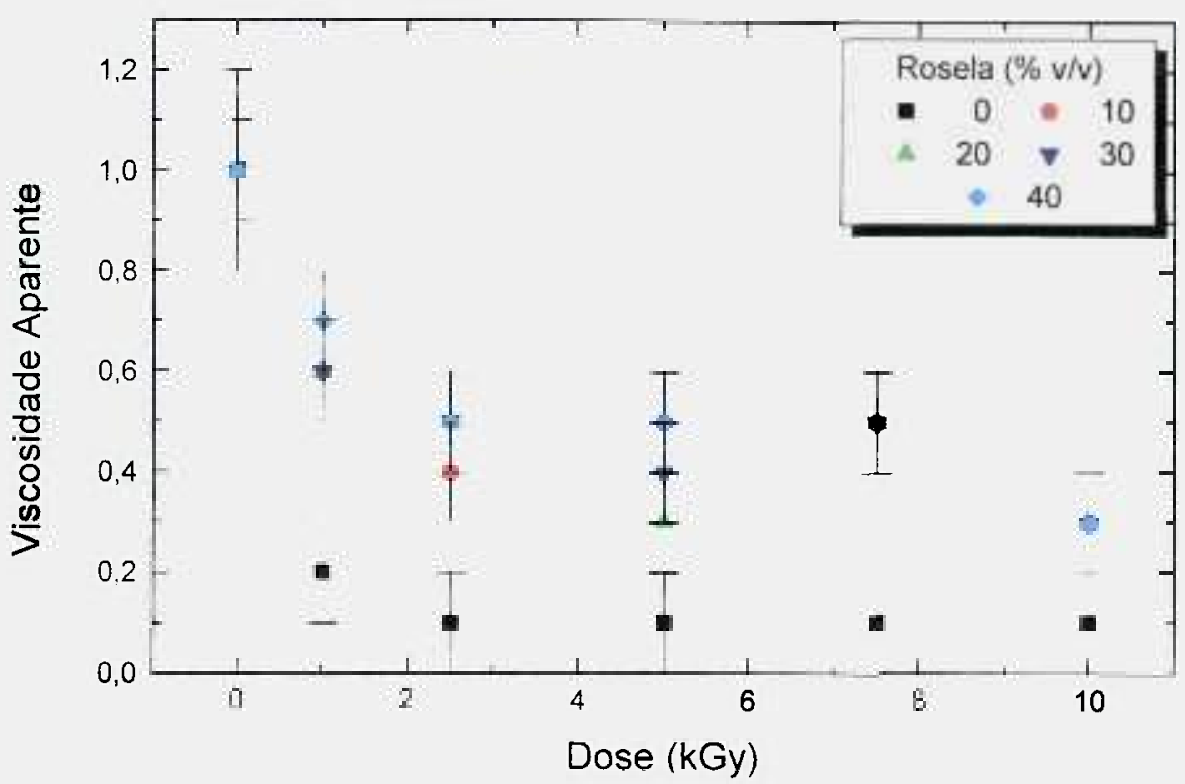

Figura 19b - Viscosidade em função da dose, das soluções de carragenana na presença de diferentes concentrações de extrato de rosela, à taxa de cisalhamento de $330 \mathrm{~s}^{-1}$ e $60^{\circ} \mathrm{C}$ (dados normalizados). 
Tabela 8 - Medidas do pH das soluções de carragenana em função da dose e da concentração de extrato de rosela.

\begin{tabular}{cccccc}
\hline \multirow{2}{*}{ Dose (kGy) } & \multicolumn{5}{c}{ Concentração de extrato de rosela $(\% \overline{v / v})$} \\
\cline { 2 - 6 } & 0,0 & 10 & 20 & 30 & 40 \\
\hline 0,0 & 6,1 & 2,8 & 2,6 & 2,6 & 2,5 \\
1,0 & 5,6 & 2,8 & 2,6 & 2,6 & 2,5 \\
2,5 & 5,3 & 2,8 & 2,7 & 2,6 & 2,5 \\
5,0 & 4,5 & 2,9 & 2,7 & 2,6 & 2,6 \\
7,5 & 3,9 & 2,9 & 2,7 & 2,6 & 2,6 \\
10,0 & 3,8 & 2,9 & 2,7 & 2,6 & 2,5 \\
\hline
\end{tabular}

A influência do extrato de rosela sobre o comportamento das soluções de alginato de sódio frente à radiação, está ilustrada nas Figuras $20 \mathrm{a}$ e 20b. É possivel observar um aumento da viscosidade induzido apenas pela adição do extrato.

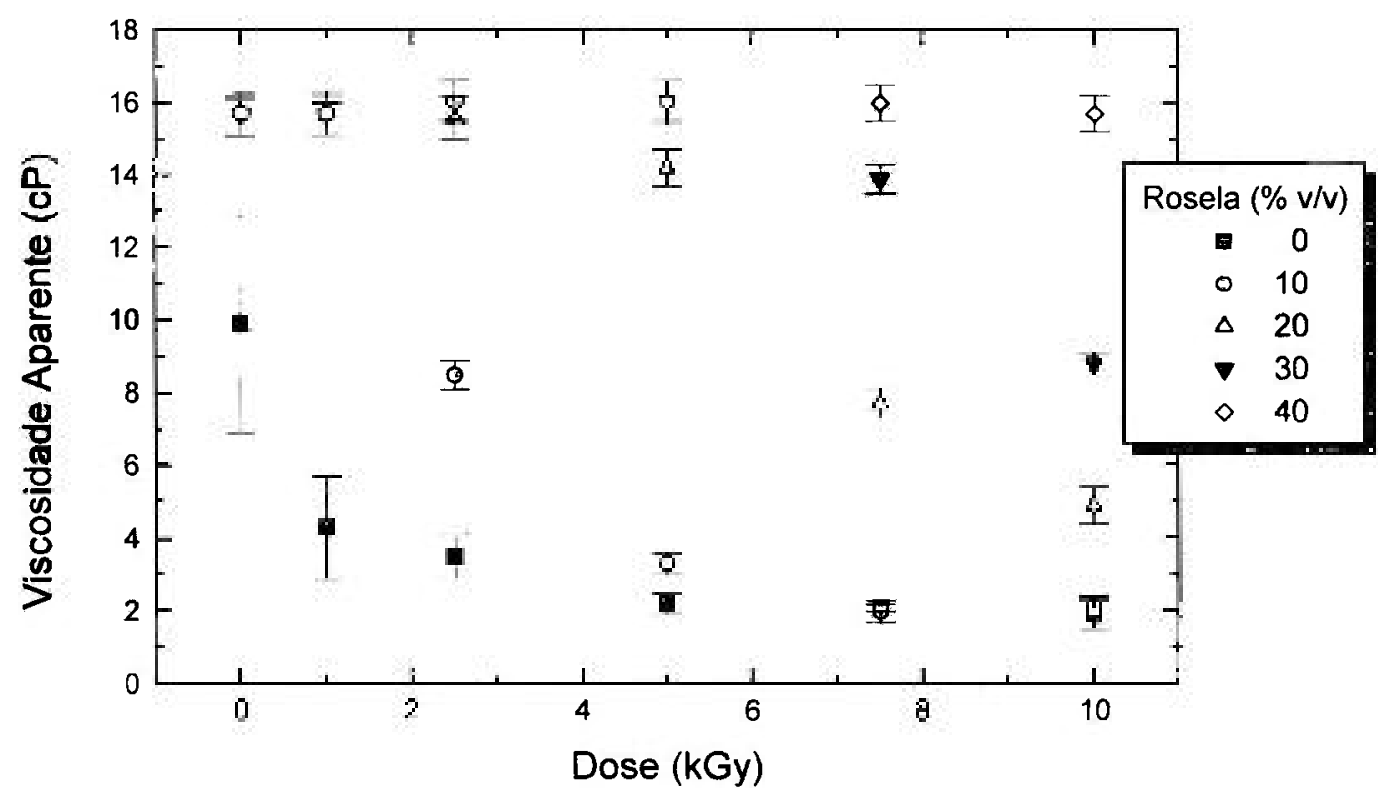

Figura 20a - Viscosidade em função da dose, das soluções de alginato de sódio na presença de diferentes concentrações de extrato de rosela, à taxa de cisalhamento de $330 \mathrm{~s}^{-1}$ e $45^{\circ} \mathrm{C}$ 
Há um aumento da viscosidade na presença de concentrações crescentes de rosela, o que pode ser interpretado como um comportamento radioprotetor, sendo que para a concentração maior a proteção é quase total, não havendo mudança da viscosidade com o aumento da dose.

Tabela 9 - Medidas do pH das soluções de alginato de sódio em função da dose e da concentração de rosela.

\begin{tabular}{cccccc}
\hline \multirow{2}{*}{ Dose (kGy) } & \multicolumn{5}{c}{ Concentração de extrato de rosela (\%v/v) } \\
\cline { 2 - 6 } & 0,0 & 10 & 20 & 30 & 40 \\
\hline 0,0 & 7,0 & 3,9 & 3,3 & 3,0 & 3,0 \\
1,0 & 6,5 & 4,0 & 3,6 & 3,3 & 3,2 \\
2,5 & 6,5 & 4,0, & 3,5 & 3,2 & 3,1 \\
5,0 & 7,1 & 3,8, & 3,4 & 3,1 & 3,0 \\
7,5 & 7,2 & 4,0 & 3,5 & 3,3 & 3,2 \\
10,0 & 6,3 & 3,8 & 3,4 & 3,2 & 3,0 \\
\hline
\end{tabular}

$\mathrm{Na}$ Tabela 9 estão os valores de $\mathrm{pH}$ das soluções de alginato de sódio acrescidas das várias concentrações de extrato de rosela ensaiadas, mostrando constância em relação à dose. 


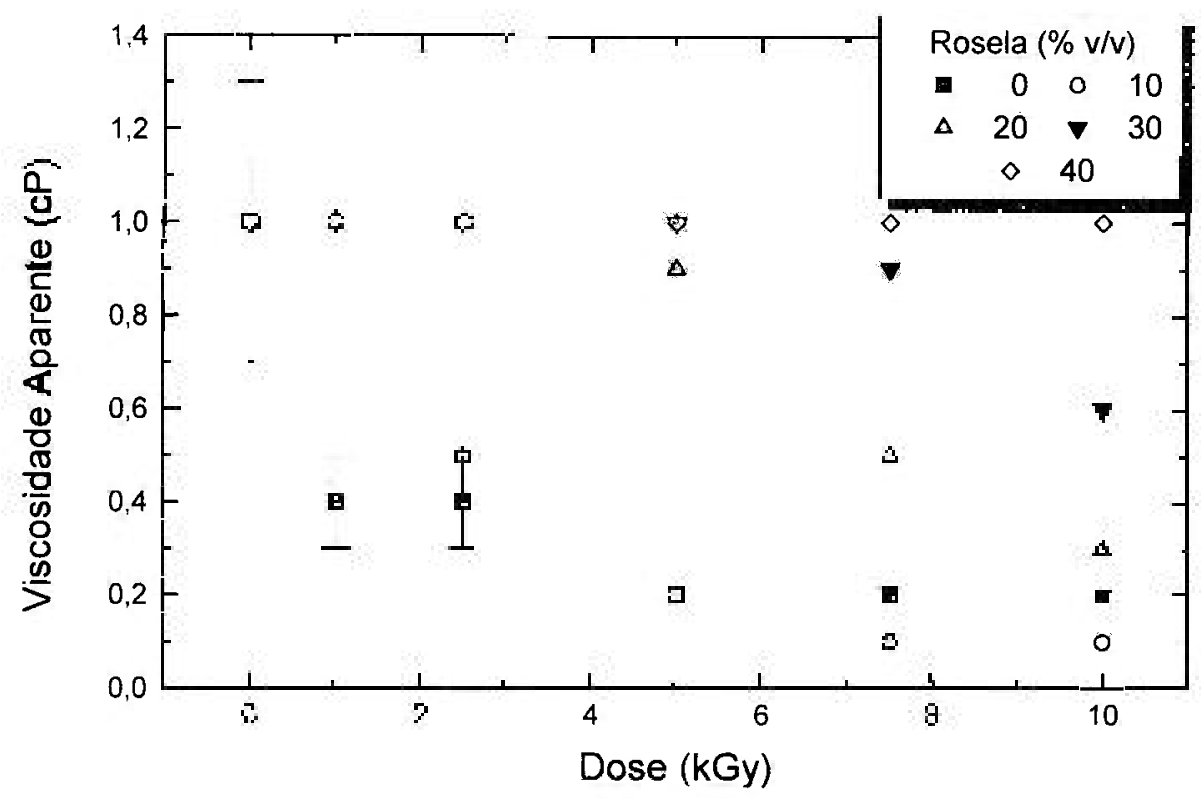

Figura 20b - Viscosidade em função da dose, das soluções de alginato de sódio na presença de diferentes concentrações de extrato de rosela, à taxa de cisalhamento de $330 \mathrm{~s}^{-1}$ e $45^{\circ} \mathrm{C}$ (dados normalizados).

Tabela 10 - Comparação da significância estatística $(P)$ das soluções de agarana, carragenana e alginato de sódio entre irradiado e não irradiado (método t de Student)

\begin{tabular}{cccccc}
\hline \multirow{2}{*}{ Hidrocolóide } & \multicolumn{5}{c}{ Concentração de extrato de rosela (\% v/v) } \\
\cline { 2 - 6 } & 0,0 & 10 & 20 & 30 & 40 \\
\hline Agarana & 0,22 & 0,58 & 0,20 & 0,63 & 0,03 \\
Carragenana & 0,96 & 0,31 & 0,27 & 0,25 & 0,38 \\
Alginato de sódio & 0,86 & 0,28 & 0,01 & $\underline{0,00}$ & 0,00 \\
\hline
\end{tabular}

$\mathrm{Na}$ Tabela 10 constam os valores do teste t de Student encontrados para a ação do extrato de rosela nos sistemas de soluções de polissacarídeos. No caso da agarana, há uma influência significativa da ação da radiação sobre o polissacarídeo para todas as concentrações empregadas (todos os valores inferiores a 0,68 ). Para carragenana e alginato de sódio haveria uma diferença 
estatisticamente significativa apenas para as soluções acrescidas de extrato de rosela, o que caracteriza um comportamento estatisticamente radioprotetor.

\subsection{Isoflavona de soja}

O comportamento da viscosidade das soluções de agarana adicionadas ou não de isoflavona de soja está representado nas Figuras 21a, 21b. Nessas figuras é possivel perceber que a isoflavona induz um aumento da viscosidade da solução de agarana para todas as concentrações ensaiadas. Apenas para a menor concentração de $0,5 \mathrm{~g} \cdot \mathrm{L}^{-1}$ não haveria evidências de radioproteção, quando as amostras foram irradiadas com as doses mais altas.

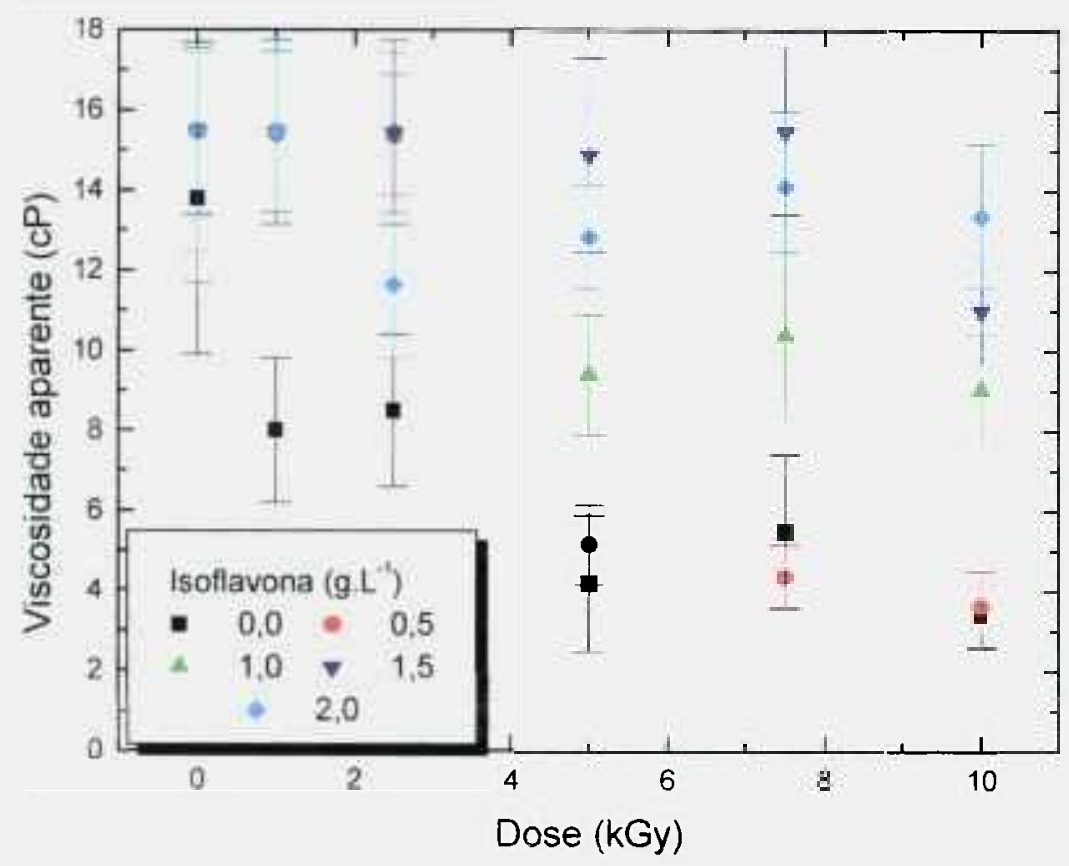

Figura 21a - Viscosidade em função da dose, das soluções de agarana na presença de diferentes concentrações de isoflavona de soja, à taxa de cisalhamento de $330 \mathrm{~s}^{-1}$ e $60^{\circ} \mathrm{C}$. 


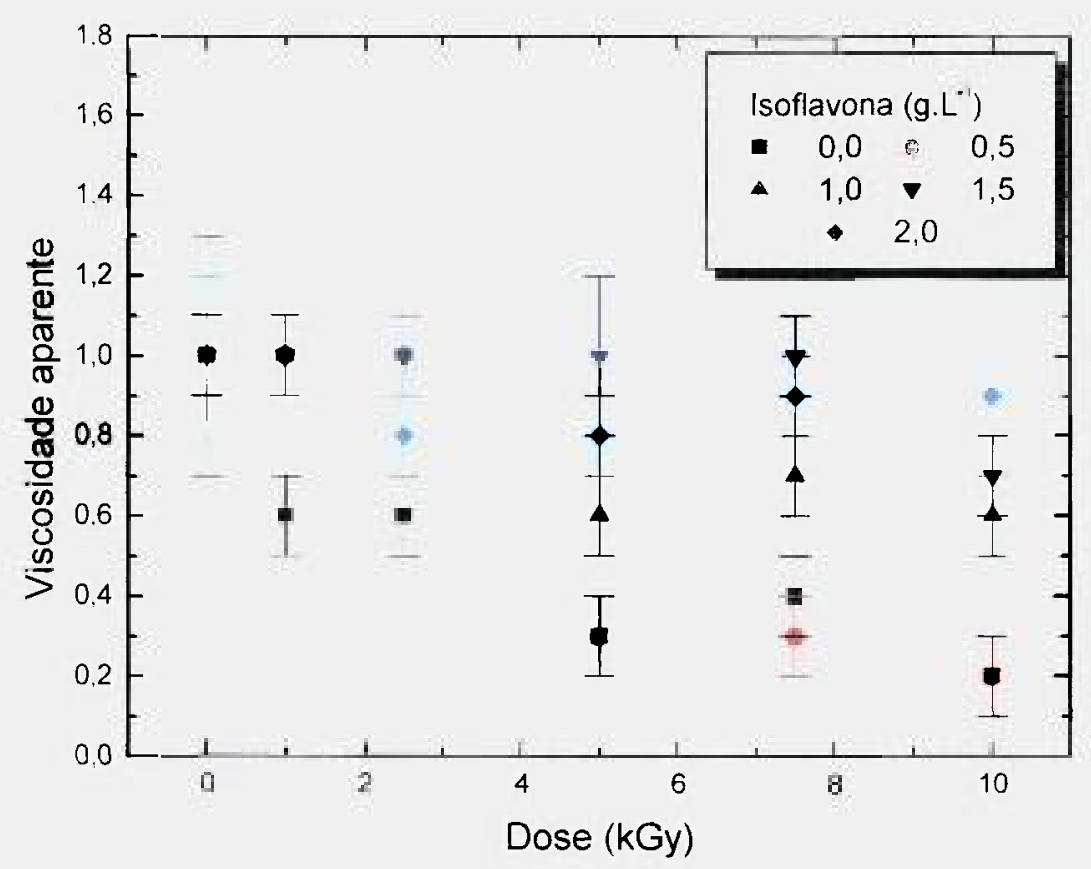

Figura 21b - Viscosidade em função da dose, das soluções de agarana na presença de diferentes concentrações de isoflavona de soja, à taxa de cisalhamento de $330 \mathrm{~s}^{-1}$ e $60^{\circ} \mathrm{C}$ (sem normalização).

$\mathrm{O} \mathrm{pH}$ das soluções de agarana praticamente não variou com a dose nem com a concentração de isoflavona de soja (Tabela 11).

Tabela 11 - Medidas do pH das soluções de agarana em função da dose e da concentração de isoflavona de soja.

\begin{tabular}{cccccc}
\hline \multirow{2}{*}{ Dose (kGy) } & \multicolumn{5}{c}{ Concentração de isoflavona de soja $\left(\mathbf{g} \cdot \mathrm{L}^{-1}\right)$} \\
\cline { 2 - 6 } & 0,0 & 0,5 & 1,0 & 1,5 & 2,0 \\
\hline 0,0 & 5,5 & 6,9 & 6,9 & 6,8 & 6,6 \\
1,0 & 5,6 & 6,6 & 6,7 & 6,5 & 6,7 \\
2,5 & 5,2 & 6,6 & 6,5 & 6,6 & 6,7 \\
5,0 & 4,5 & 6,1 & 6,4 & 6,4 & 6,6 \\
7,5 & 4,1 & 6,0 & 6,2 & 6,4 & 6,5 \\
10,0 & 4,1 & 6,0 & 6,2 & 6,0 & 6,4 \\
\hline
\end{tabular}


O comportamento da viscosidade das soluções de carragenana com e sem isoflavona de soja estão nas Figuras 22a e 22b. Apenas para as maiores concentrações ensaiadas é possível perceber uma tendência de radioproteção.

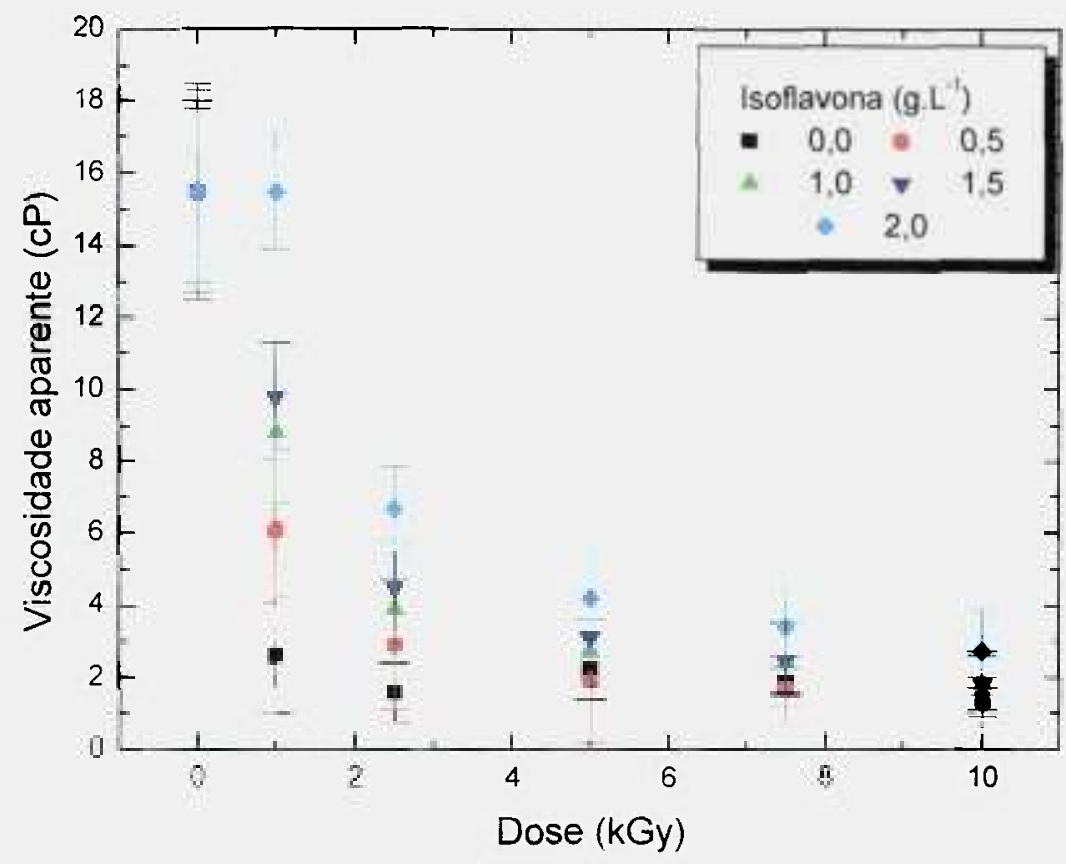

Figura 22a - Viscosidade em função da dose, das soluções de carragenana na presença de diferentes concentrações de isoflavona de soja, à taxa de cisalhamento de $330 \mathrm{~s}^{-1}$ e $60^{\circ} \mathrm{C}$. 


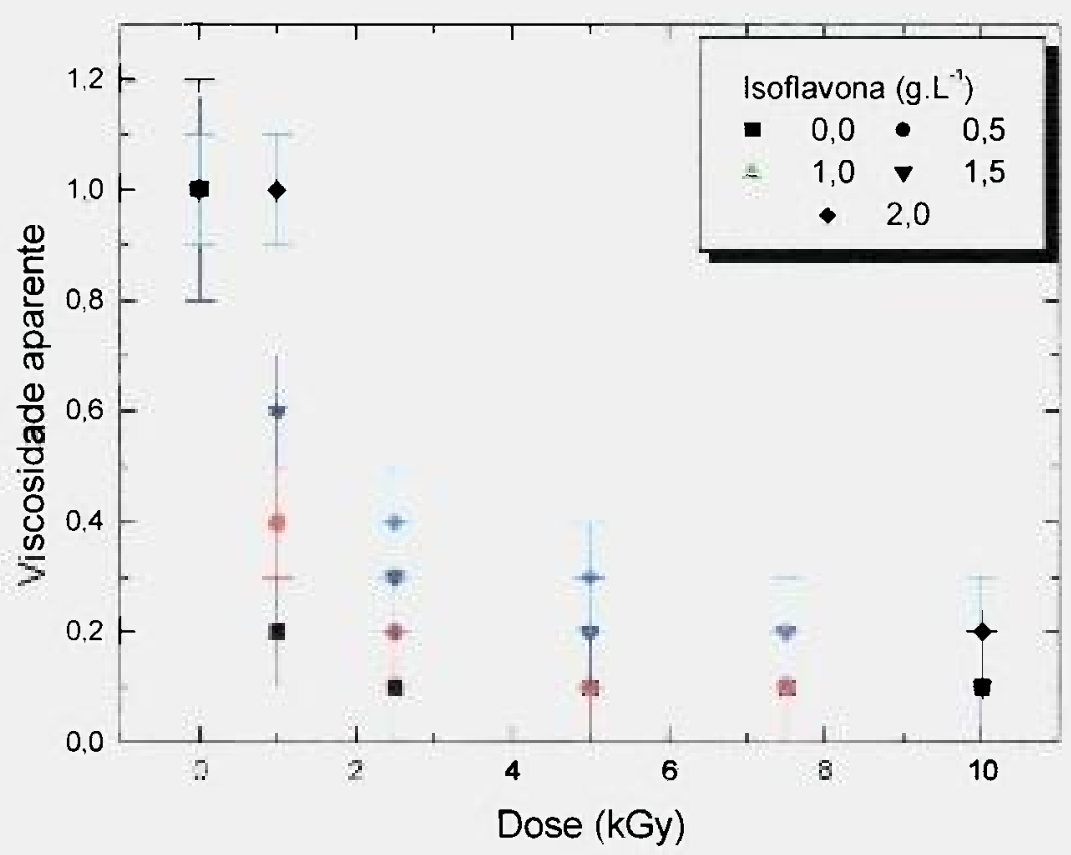

Figura 22b - Viscosidade em função da dose, das soluções de carragenana na presença de diferentes concentrações de isoflavona de soja, à taxa de cisalhamento de $330 \mathrm{~s}^{-1}$ e $60^{\circ} \mathrm{C}$ (dados normalizados).

Pela Tabela 12 verifica-se que houve variação do $\mathrm{pH}$ de soluções de carragenana em função da dose e da concentração de isoflavona de soja.

Tabela 12 - Medidas do pH das soluções de carragenana em função da dose e da concentração de isoflavona de soja.

\begin{tabular}{cccccc}
\hline \multirow{2}{*}{ Dose (kGy) } & \multicolumn{5}{c}{ Concentração de isoflavona $\left(\mathrm{g} \cdot \mathrm{L}^{-1}\right)$} \\
\cline { 2 - 6 } & 0,0 & 0,5 & 1,0 & 1,5 & 2,0 \\
\hline 0,0 & 6,1 & 6,4 & 7,4 & 7,5 & 8,1 \\
1,0 & 5,6 & 8,0 & 6,1 & 8,0 & 7,9 \\
2,5 & 5,3 & 7,4 & 8,1 & 6,8 & 7,0 \\
5,0 & 4,5 & 6,3 & 6,5 & 6,5 & 6,6 \\
7,5 & 3,9 & 5,9 & 6,2 & 6,4 & 6,5 \\
10,0 & 3,8 & 6,0 & 6,5 & 6,6 & 6,4 \\
\hline
\end{tabular}




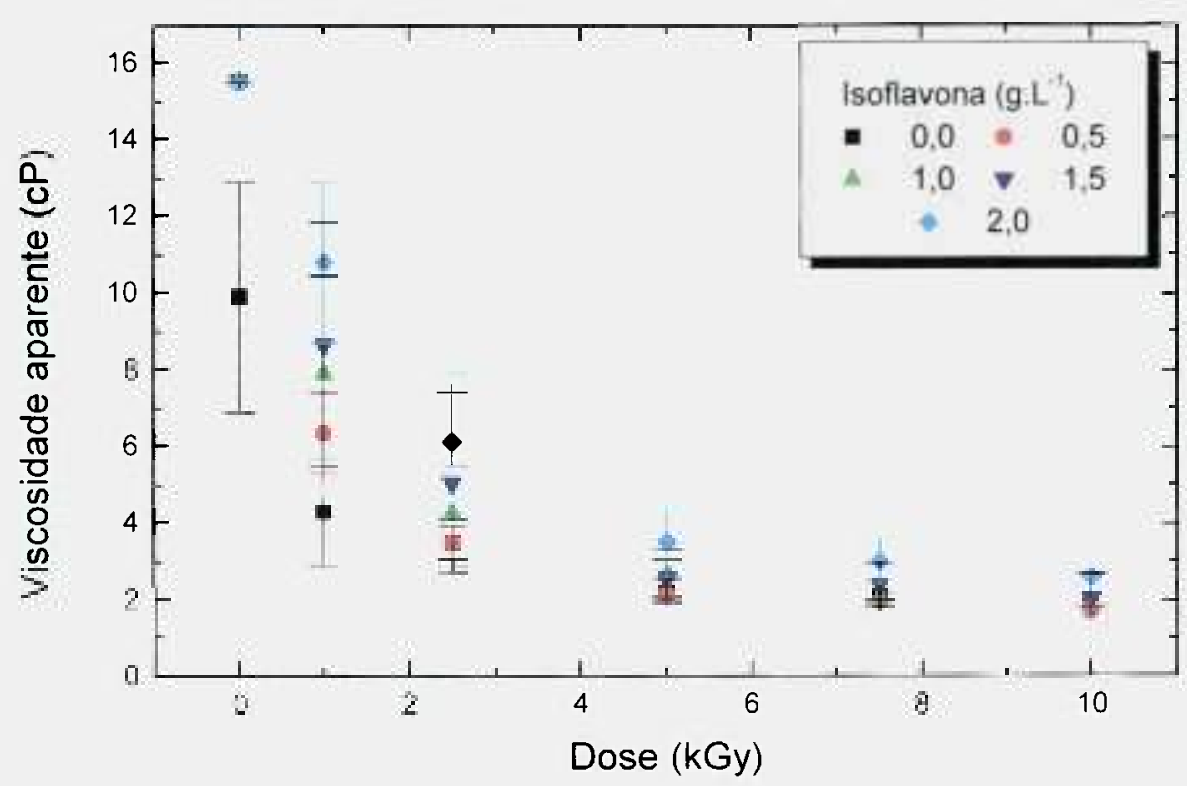

Figura 23a - Viscosidade em função da dose, das soluções de alginato de sódio na presença de diferentes concentrações de isoflavona de soja, à taxa de cisalhamento de $330 \mathrm{~s}^{-1}$ e $45^{\circ} \mathrm{C}$.

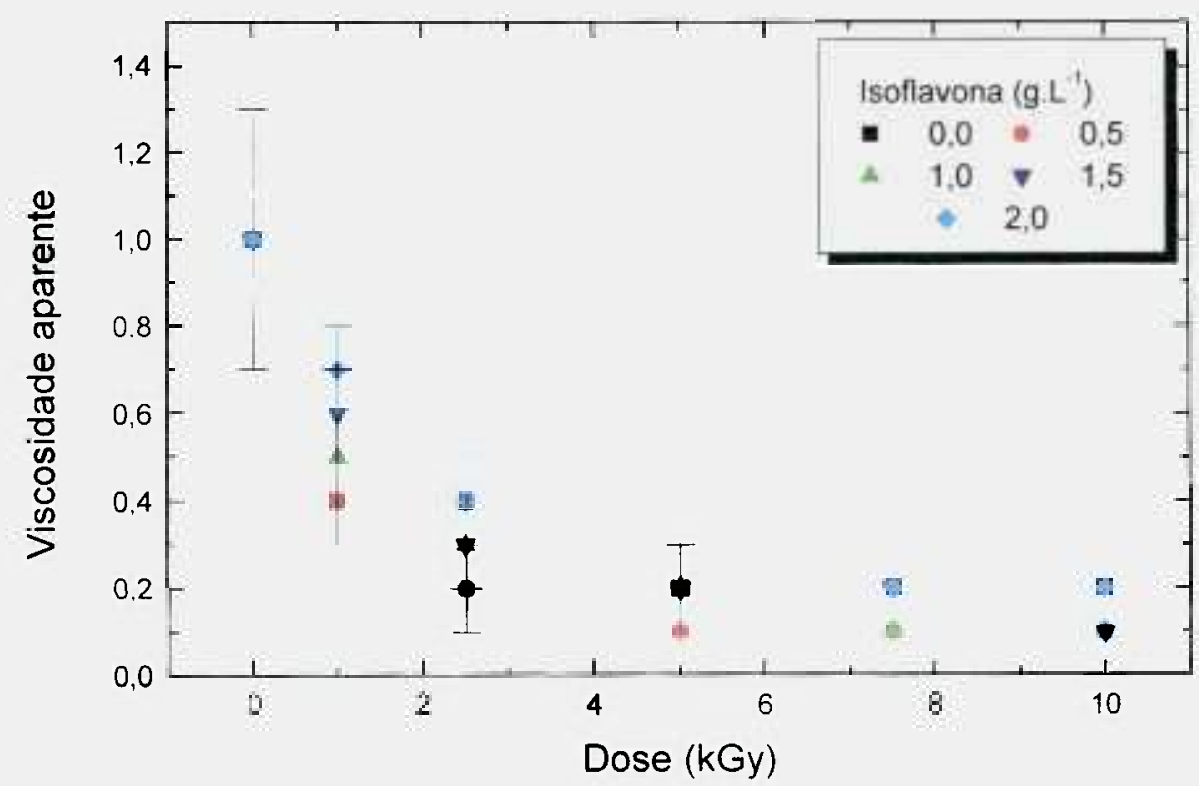

Figura 23b - Viscosidade em função da dose das soluções de alginato de sódio na presença de diferentes concentrações de isoflavona de soja, à taxa de cisalhamento de $330 \mathrm{~s}^{-1}$ e $45^{\circ} \mathrm{C}$ (dados normalizados). 
As viscosidades das soluções de alginato de sódio com a adição de isoflavona de soja estão apresentadas nas Figuras 23a.e 23b. A isoflavona foi capaz de induzir aumento da viscosidade da solução de alginato. $O$ efeito radioprotetor, entretanto, não é evidente.

Os valores de $\mathrm{pH}$ das soluções de alginato de sódio em função da dose e da concentração isoflavona de soja constam da Tabela 13.

Tabela 13 - Medidas do pH das soluções de alginato de sódio em função da dose e da concentração isoflavona de soja.

\begin{tabular}{cccccc}
\hline \multirow{2}{*}{ Dose (kGy) } & \multicolumn{5}{c}{ Concentração isoflavona de soja $\left(\mathrm{g} \cdot \mathrm{L}^{-1}\right)$} \\
\cline { 2 - 6 } & 0,0 & 0,5 & 1,0 & 1,5 & 2,0 \\
\hline 0,0 & 7,0 & 7,4 & 7,3 & 6,6 & 6,8 \\
1,0 & 6,5 & 6,8 & 6,9 & 6,8 & 6,9 \\
2,5 & 6,5 & 7,1 & 6,9 & 6,9 & 6,9 \\
5,0 & 7,1 & 7,0 & 7,0 & 7,5 & 6,9 \\
7,5 & 7,2 & 7,0 & 6,9 & 7,1 & 6,9 \\
10,0 & 6,3 & 7,0 & 6,9 & 6,7 & 6,8 \\
\hline
\end{tabular}

Na Tabela 14 são apresentados os valores do teste $\mathrm{t}$ de Student para análise do efeito de isoflavona no comportamento reológico dos polissacarídeos ensaiados. Para a agarana há uma diferença significativa do comportamento reológico das amostras com ou sem o tratamento pela irradiação, seja na presença ou não de isoflavona. Entretanto, para carragenana e alginato de sódio, esse efeito só é perceptível para concentrações de isoflavona de $1,0 \mathrm{~g} \cdot \mathrm{L}^{-1} \mathrm{e}$ maiores. 
Tabela 14 - Comparação da significância estatística $(P)$ das soluções de agarana, carragenana e alginato de sódio entre irradiado e não irradiado (método $t$ de Student).

\begin{tabular}{cccccc}
\hline \multirow{2}{*}{ Hidrocolóide } & \multicolumn{5}{c}{ Concentração de isoflavona de soja $\left(\mathrm{g} \cdot \mathrm{L}^{-1}\right)$} \\
\cline { 2 - 6 } & 0,0 & 0,5 & 1,0 & 1,5 & 2,0 \\
\hline Agarana & 0,22 & 0,09 & 0,00 & 0,00 & 0,00 \\
Carragenana & 0,96 & 0,84 & 0,59 & 0,51 & 0,24 \\
Alginato de sódio & 0,86 & 0,75 & 0,62 & 0,54 & 0,35 \\
\hline
\end{tabular}

\section{DISCUSSÃO}

Seja na área da saúde ou em ciência dos alimentos, o interesse sobre a ação da radiação em sistemas polissacarídicos é no sentido de poder produzir um efeito biológico previsivel, mesmo que o efeito observado seja sempre resultado de uma inumerável quantidade de reações complicadas, produzidas por processos de transferência físicos e químicos e recombinações.

O conhecimento da ação da radiação sobre carboidratos deriva fundamentalmente de estudos sobre radiólise de soluções aquosas e mudanças radioinduzidas em monossacarídeos e polissacarídeos no estado sólido (IAEA, 1973; YOSHII, 2004). Graças a esses estudos sabe-se que quando polissacarídeos são submetidos à radiação ionizante aparece como mudança fundamental à despolimerização via a cisão da cadeia polimérica. O decréscimo apreciável na massa molecular na presença de oxigênio é também atribuido a esse fenômeno. A radiólise de moléculas envolvidas na estrutura hidrocoloidal é que conduziria à formação de macroradicais primários, degradação e perda de estrutura cristalina (KOROTCHENKO \& SHARPATYI, 2004). Por outro lado, há evidências (REDDY \& TAMMISHETTI, 2004) de que uma degradação mediada por radicais livres também ocorre por ação de peróxido de hidrogênio sobre soluções de polissacarídeos.

O processamento por radiação gama é considerado o método mais efetivo de degradação de polissacarídeos do tipo dos alginatos quando 
comparado com a ação de outros métodos como ultra-som ou radiação UV (WASIKIEWICZ et al., 2005). A literatura contém também referências à degradação radioinduzida de carragenana (RELLEVE et al., 2005; ALISTE, 1999). WASIKIEWICZ et al.(2005), pesquisando sobre quitosana e alginato, concluíram que um dos efeitos da radiação nesses polímeros é a quebra das ligações glicosidicas. Já RELLEVE et al.(2005) submetendo a carragenana a irradiação constataram que ela sofre uma dessulfatação.

Com base nesse conhecimento é que foram escolhidos como sistemas de estudo as soluções de três polissacarídeos amplamente utilizados na indústria de alimentos para verificar neles a possivel ação radioprotetora de antioxidantes também comestiveis. Se por um lado eles podem ser utilizados com esse objetivo como no presente estudo, por outro lado à própria sensibilidade desses polissacarídeos frente ao estresse oxidativo pode ser aproveitada como potencial antioxidativo para outras moléculas presentes (TROMMER \& NEUBER, 2005).

Os valores de concentração dos antioxidantes acrescidos às soluções dos hidrocolóides, foram encontrados levando-se em conta a interferência destes na viscosidade, mesmo sem irradiação. Chegando-se a valores que pareceram ser os ideais para utilização no presente estudo.

O papel das espécies reativas de oxigênio no dano por radiação e o potencial de antioxidantes de agirem para reduzir esses efeitos deletérios tem sido estudado em modelos animais por mais de 50 anos, sendo considerados os antioxidantes naturais como menos efetivos que aqueles provenientes de síntese (WEISS \& LANDAUER, 2000).

O efeito da radiação nos polissacarídeos agarana, carragenana e alginato em pó (ALISTE et al., 2000) já consta na literatura. Os dados apresentados no presente trabalho sobre a ação da radiação ionizante nos respectivos hidrogéis indicam também uma drástica diminuição da viscosidade destes. Assim, a produção de radicais hidroxila característica da ação da radiação em sistemas aquosos (YAMAGUCHI et al., 2005) seria a principal responsável pela quebra de ligações químicas que induziriam a diminuição da viscosidade. Em 
relação ao comportamento reológico das soluções de alginato KAYACIER \& DOGAN (2005) verificaram tambèm um comportamento não Newtoniano, ou seja, a viscosidade aparente muda com à taxa de cisalhamento.

Os dados apresentados no presente trabalho indicam que a presença do ácido ascórbico em concentraçōes de $57 \mathrm{mM}$ a $142,5 \mathrm{mM}$ afetou de forma diversa os sistemas em estudo. O próprio ácido ascórbico mostrou um forte efeito degradativo sobre os polissacarideos. Esse efeito já tinha sido mencionado por VALLES-PAMIES et al. (1997) que estudaram a degradação de amido de mandioca induzida pelo ácido ascórbico. ALISTE \& DEL MASTRO (2004) tinham achado um efeito radioprotetor do ácido ascórbico sobre soluções de carragenana quando o ácido era utilizado em concentrações de 5\%, 10\%, 15\% e 20\%, equivalentes a $285 \mathrm{mM}, 570 \mathrm{Mm}, 855 \mathrm{Mm}$ e $1,14 \mathrm{M}$ respectivamente.

O ácido ascórbico ou vitamina $C$ é um conhecido antioxidante e por essa propriedade é geralmente incluído na formulação de produtos alimentícios (PAPAS, 1996). Embora tenha sido descrito em certos sistemas como radioprotetor (WITENBERG et al., 1999; AHN \& NAM, 2004) fica evidente que a capacidade antioxidante e o comportamento frente à ação da radiação do ácido ascórbico depende da sua concentração e do meio de experimentação. WONG \& KITTS (2001) estabeleceram que o ácido ascórbico era oxidado pela radiação ionizante proveniente de feixe de elétrons em doses entre 0 e 20kGy. Entretanto, à taxa de oxidação era crescente a concentrações mais baixas de ácido $(10 \mathrm{mM}) \mathrm{e}$ maiores doses de irradiação. Nesse estudo, o ácido ascórbico a baixas concentrações mostrou agir como pro-oxidante para uma emulsão de ácido linoléico. Entretanto, a concentrações de $500 \mathrm{mM}$ mostrou atividade como antioxidante. Os valores de concentração de ácido ascórbico utilizados no presente trabalho foram de $57 \mathrm{mM}$ a $142,5 \mathrm{mM}$, por que esses valores se mostraram melhores, após vários estudos, para o estudo da variação da viscosidade das soluções dos hidrocolóides. Valores de concentração maiores que este, causaram interferência na gelificação dos hidrocolóides.

Num trabalho recente, FAN (2005) analisou a formação de furano induzida pela irradiação de ácido ascórbico. Ele também percebeu que havia um 
valor de concentração do ácido $(0,5 \mathrm{mg} / \mathrm{mL})$ para o qual o efeito da radiação era mais pronunciado.

O ácido ascórbico também é considerado como protetor da oxidação de sistemas biológicos pela sua capacidade de reagir rapidamente com o oxigênio dissolvido para formar água, preservando o sistema da ação oxidativa do próprio oxigênio (EATON, 1991).

A radiação ionizante é capaz de induzir um aumento da extração de antioxidantes (AYED et al., 1999) e aumentar o poder antioxidante de produtos naturais em funçäo da dose (FAN \& THAYER, 2001). Assim, há vários aspectos que devem ser levados em consideração e que dificultam a interpretação de resultados dose-efeito quando da aplicação de ácido ascórbico.

Os flavonóides são compostos que vem sendo apontados como portadores de benefícios para a saúde quando da sua inclusão na dieta. Eles possuem capacidade de neutralizar radicais livres do tipo hidroxila e peroxila, mas ainda há pouca informação da quimica de reação destes fitoquimicos e de suas interações nos sistemas modelos ou com outros ingredientes dos alimentos (SHIMONI, 2004).

Dependendo da sua estrutura específica e condições, os flavonóides poderiam agir tanto como antioxidantes quanto como pro-oxidantes (CAO et al., 1997).

Há referências na literatura de trabalhos nos quais fica evidenciada a ação cooperativa de vários antioxidantes para a obtenção de efeitos benéficos (GETOFF et al., 1999; KHOPDE et al., 2001). Pesquisas publicadas em 2005 apontam para a importância da presença de mais de um flavonóides para a obtenção do efeito benéfico ( $\mathrm{JO}$ et al., 2005). Assim, um produto natural que contém vários flavonóides teria um efeito mais acentuado do que aquele atribuido a cada flavonóide purificado e ainda apresentaria maior biodisponibilidade. 
No presente trabalho, há um comportamento antioxidante e radioprotetor definido nos ensaios com extrato de rosela, que é um produto que contém vários compostos flavonóides, ácidos polifenólicos, antocianinas e ácido ascórbico (SEERAM \& NAIR, 2002). Mas no caso de isoflavona purificada de soja, esse comportamento é menos evidente. Outros autores também questionam o papel da isoflavona isolada nos efeitos benéficos deste produto (BAZZOLI et al., 2002).

\section{CONCLUSÕES}

- As soluções dos polissacarideos comestiveis agarana, carragenana e alginato de sódio, amplamente utilizados na indústria de alimentos, mostraram ser bons sistemas para avaliar o efeito da radiação ionizante por apresentarem radiossensibilidade caracteristica.

- O ácido ascórbico previne a diminuição da viscosidade induzida por radiação nesses polissacarídeos. Esse comportamento pode ser considerado como radioprotetor. Além disso o ácido ascórbico apresenta a singulariedade de induzir um aumento da viscosidade em determinadas concentrações além dos valores iniciais o que indicaria uma possivel polimerização radioinduzida.

- O extrato de rosela (Hibiscus sabdariffa L.) apresenta ação radioprotetora quando inserida em sistemas compostos por soluções dos polissacarideos agaranas, carragenanas e alginato de sódio, sendo este efeito notado em apenas algumas concentrações no caso de agarana.

- A genisteína, isoflavona isolada de soja apresenta ação radioprotetora apenas para as concentrações iguais ou maiores de $1,5 \mathrm{~g} / \mathrm{L}$ quando 0 sistema em estudo é a solução de carragenana e alginato de sódio. 
- Segundo os resultados obtidos, o extrato de rosela poderia ser considerado como 0 agente antioxidante de melhor desempenho radioprotetor para os sistemas estudados.

- O conhecimento do comportamento dos diversos ingredientes dos alimentos frente à radiação ionizante poderá permitir uma aplicação em grande escala desse processamento como mecanismo de segurança alimentar. O presente trabalho implica numa contribuição efetiva no esclarecimento do papel de antioxidantes quando presentes na irradiação de importantes aditivos alimentares. 
요

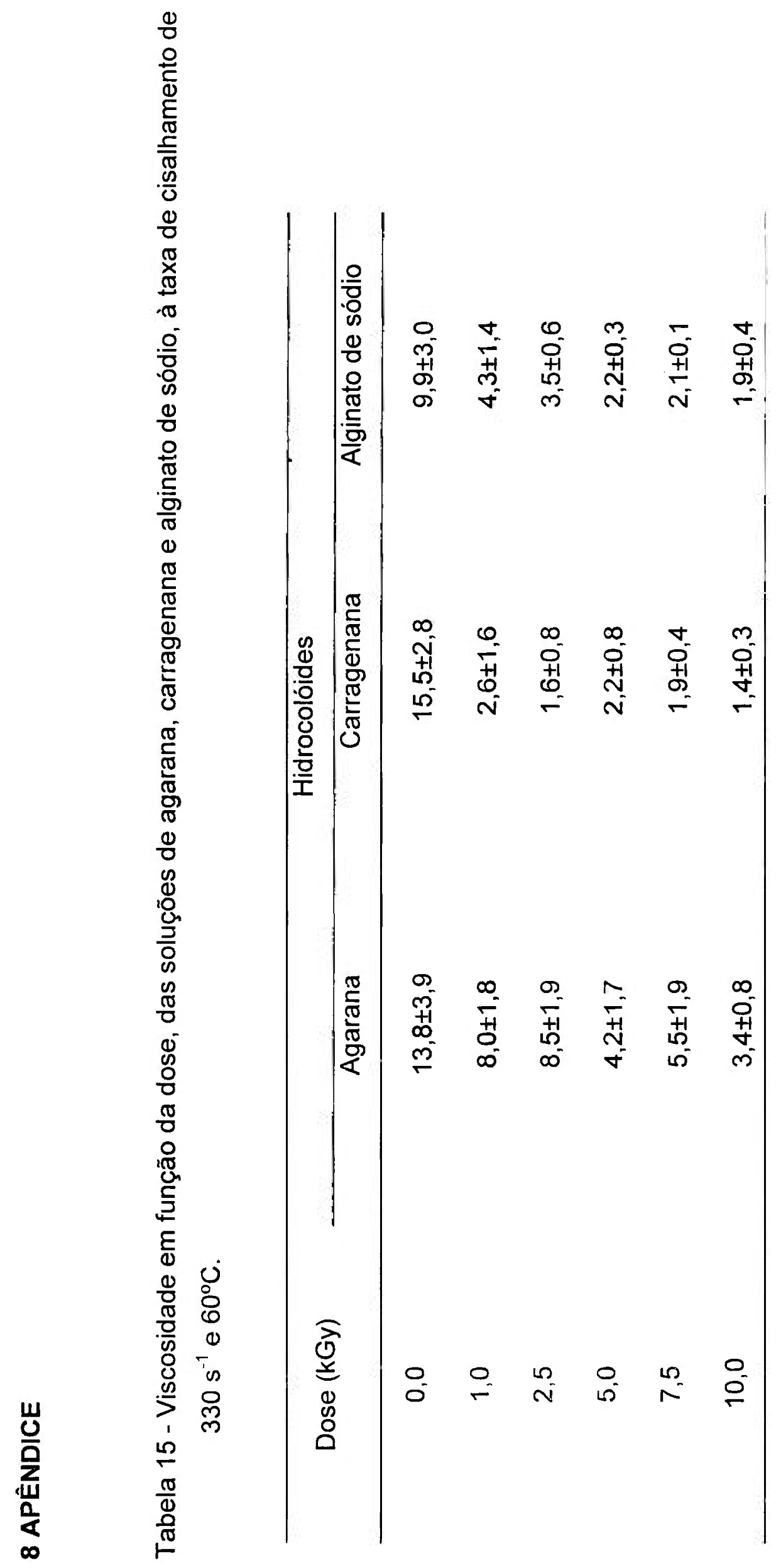




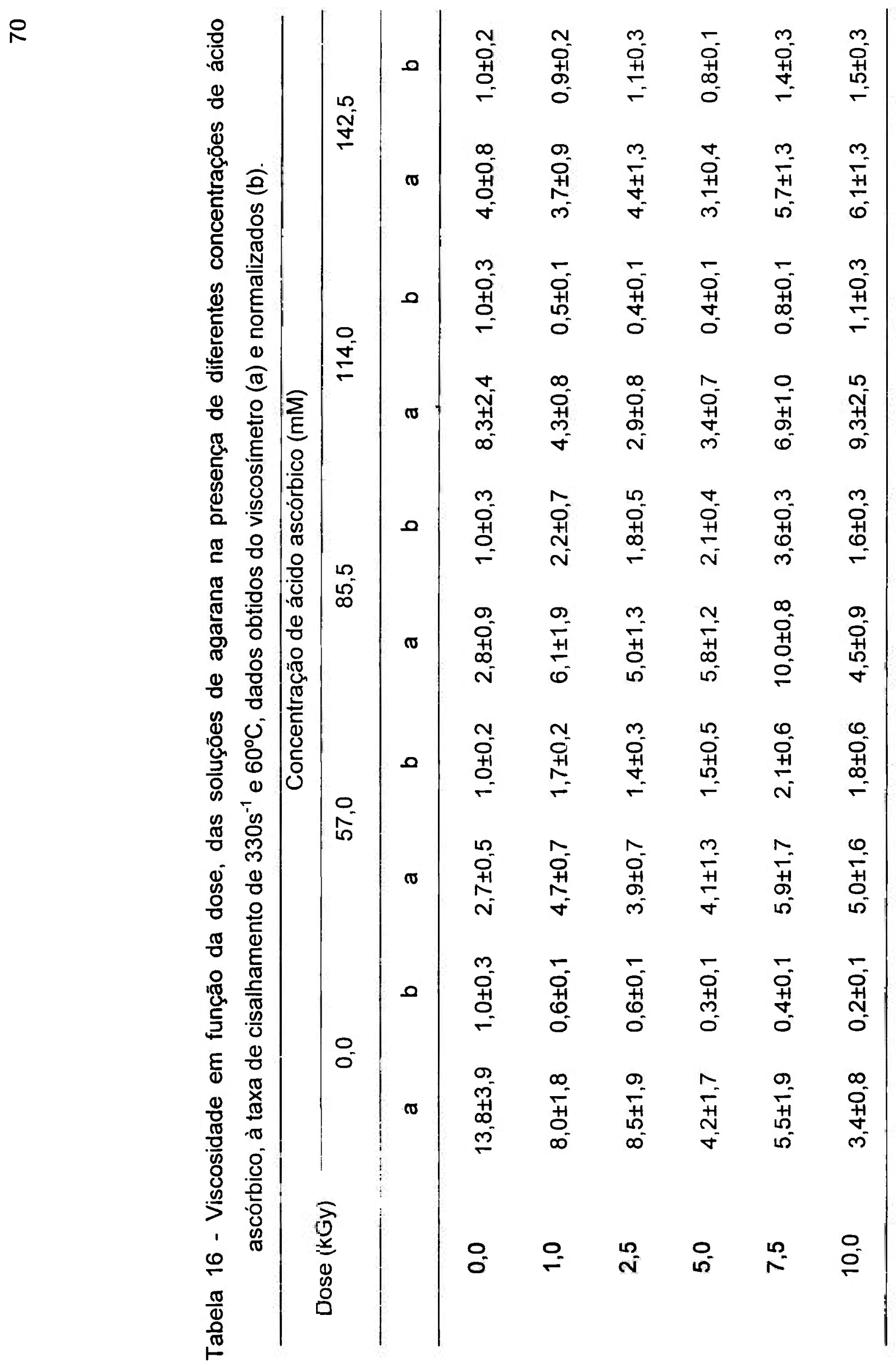




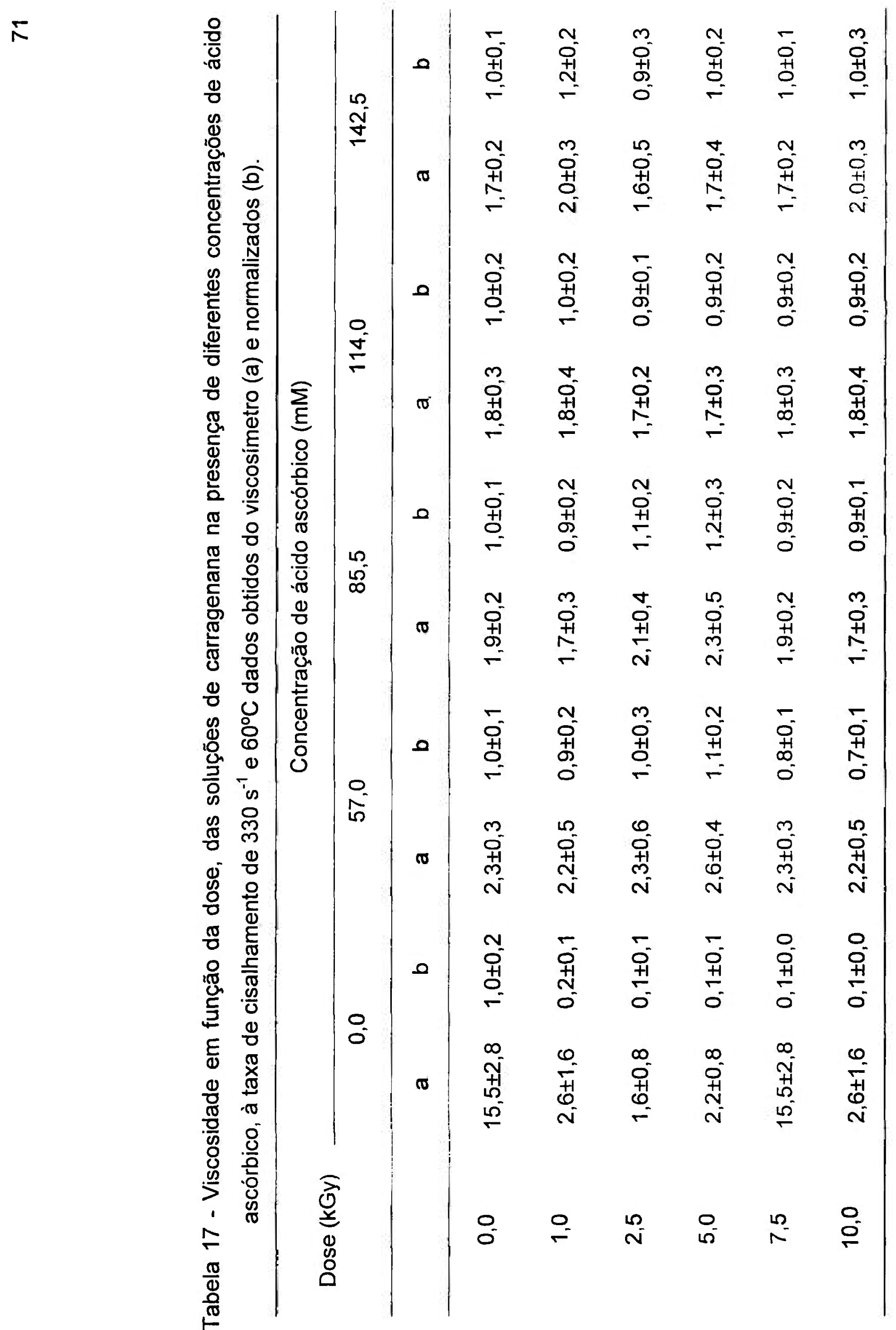




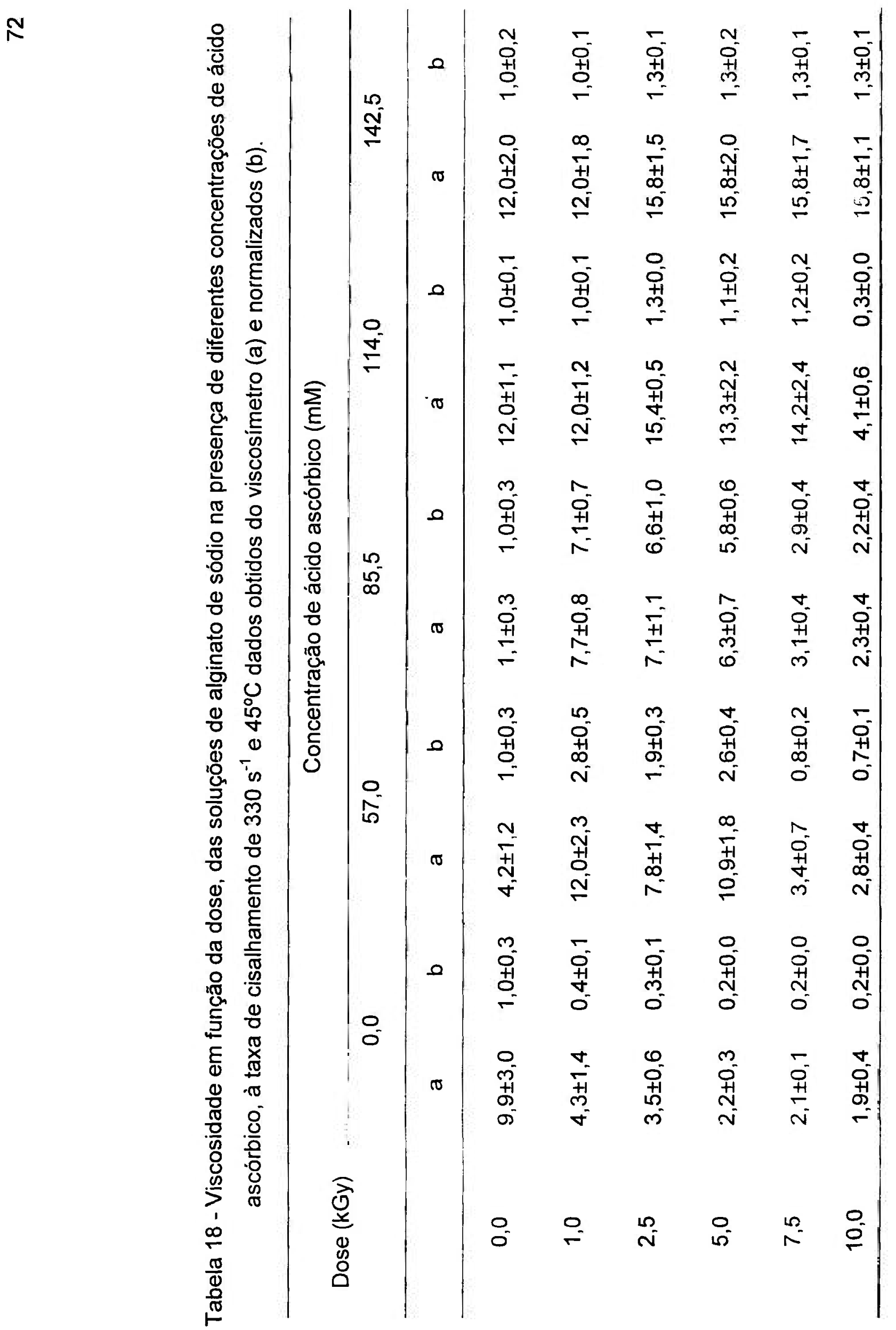


2

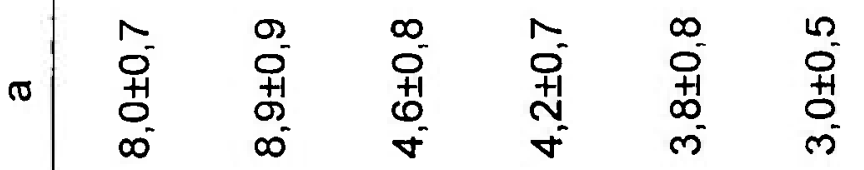

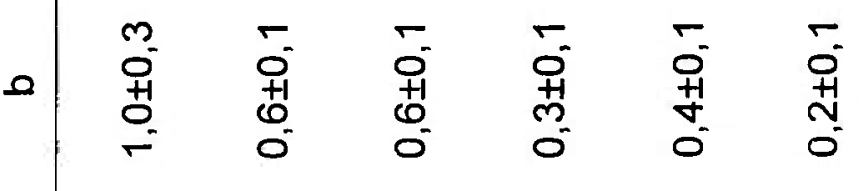

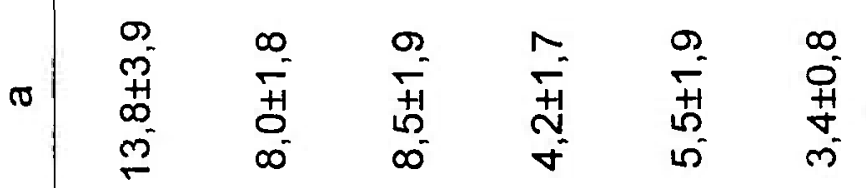
$\frac{\pi}{\frac{\pi}{6}}$

웅

ก is in 


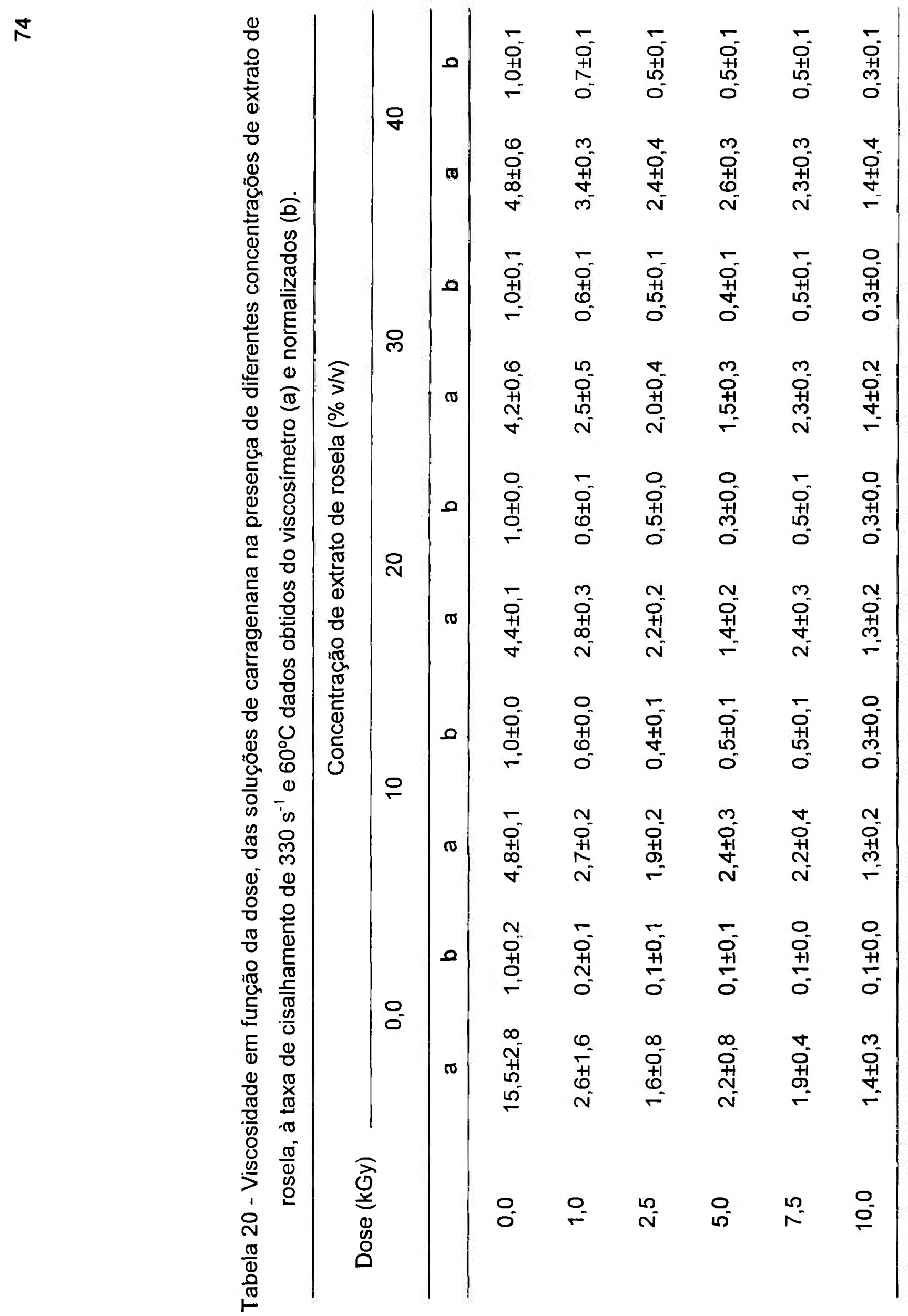


$\stackrel{2}{\sim}$

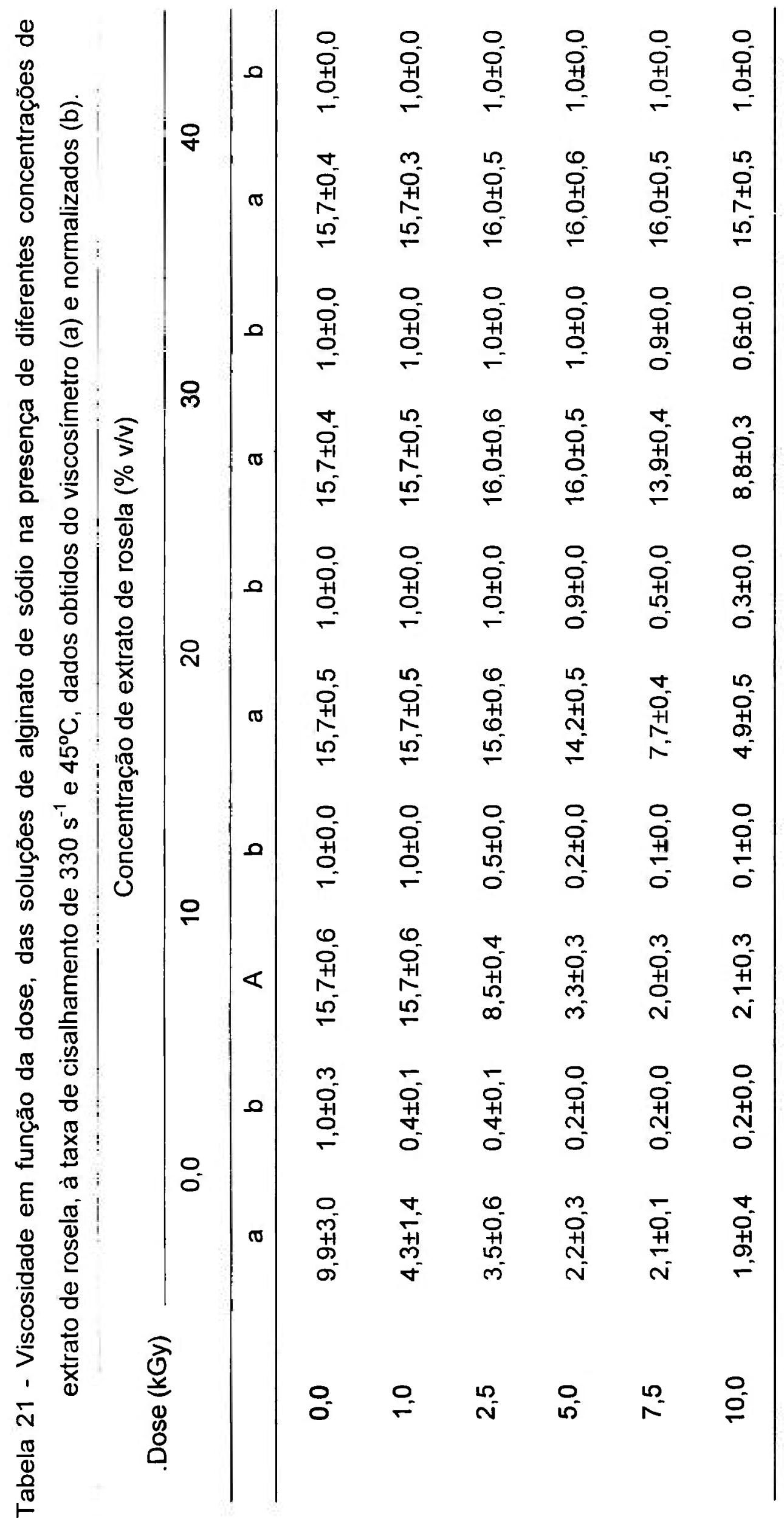


$\stackrel{0}{1}$

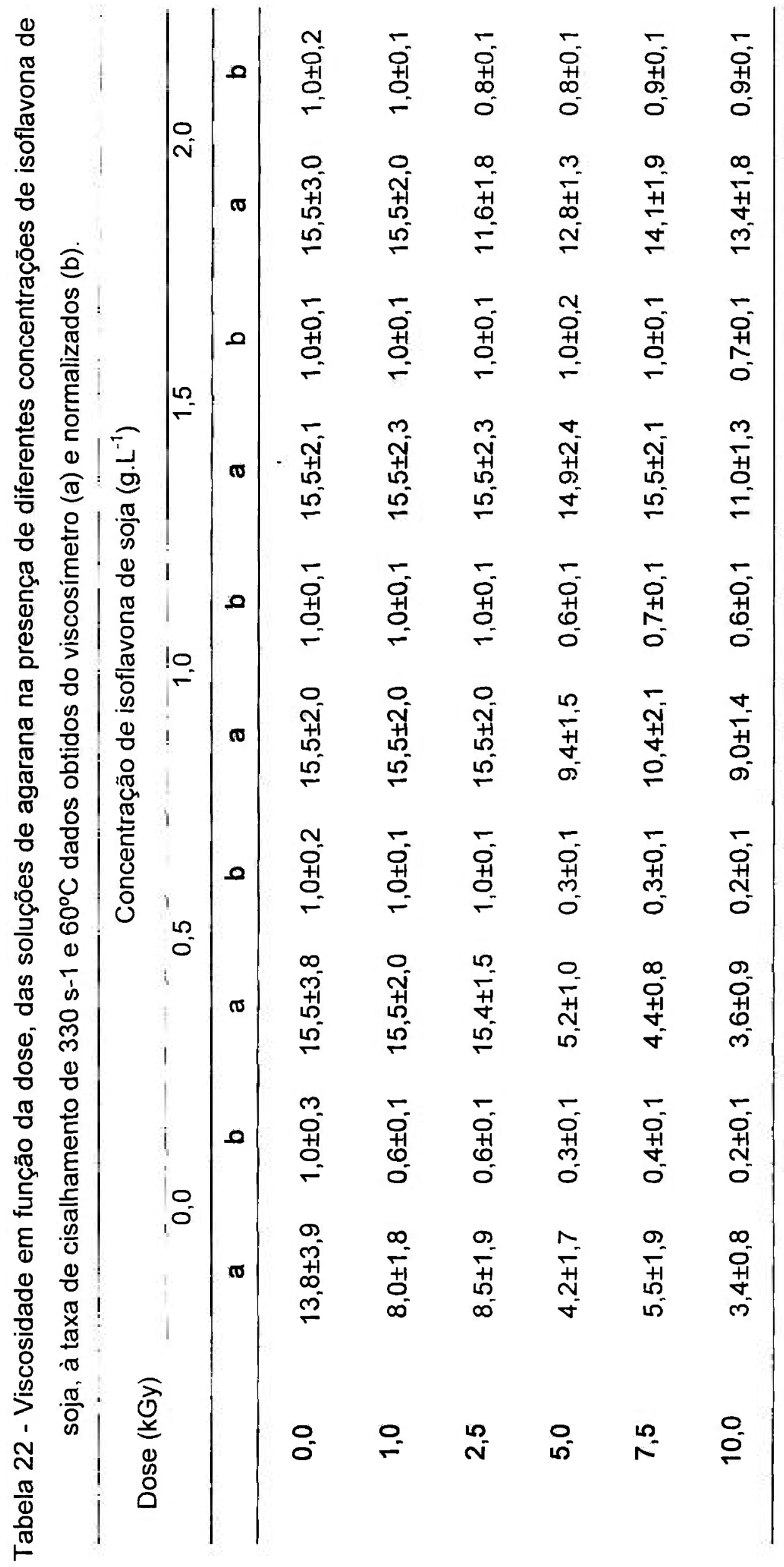




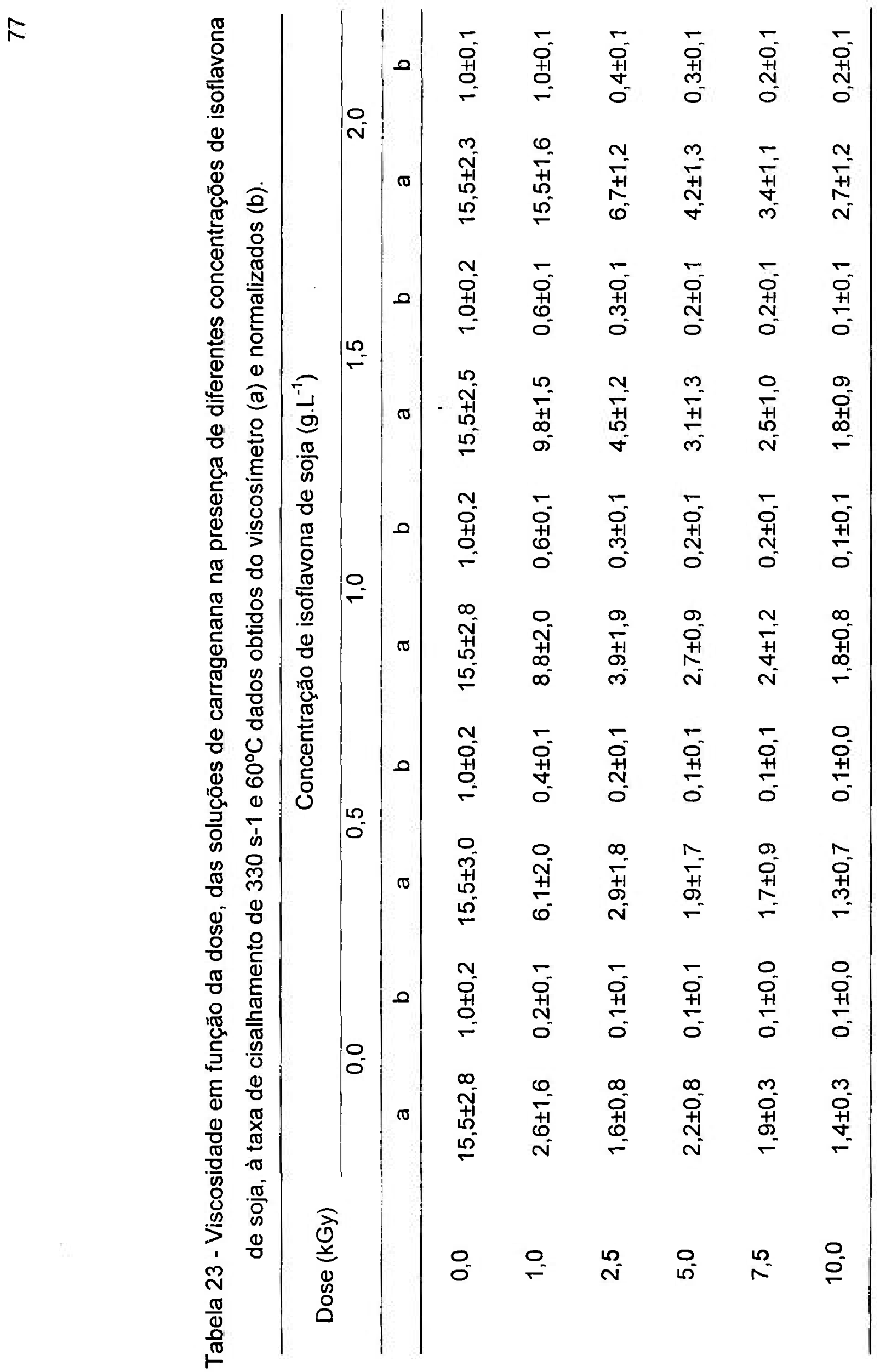


$\stackrel{\infty}{\wedge}$

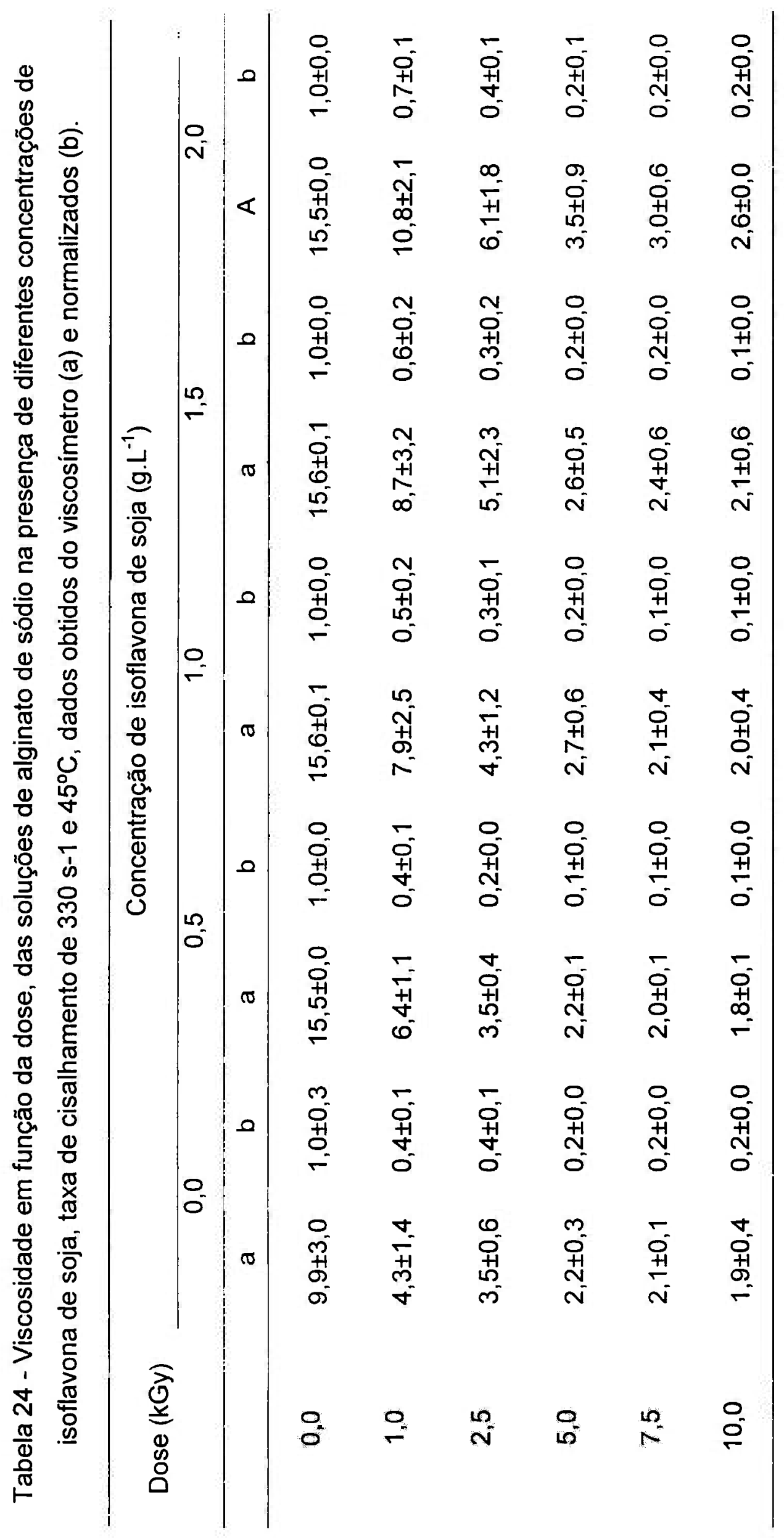




\section{REFERÊNCIAS BIBLIOGRẢFICAS}

1. AHMED, A. Emulsifiers and estabilisers - Hidrocolloids in the US. Intern. Food Ingred., v.1, n.2, p. 41-42, 2005

2. AHN, D.U.; NAM, K.C. Effects of ascorbic acid and antioxidants on color, lipid oxidation and volatiles of irradiated ground beef. Rad. Phys. Chem., v. 71 n. 1-2, p. 151-156, 2004.

3. ALGAS e alimentação humana. França-Flash Meio Ambiente Agricult., v.3, n. 12, 1997.

4. ALISTE, A.J. Efeito da radiação gama na viscosidade de carragenanas, agaranas e alginatos utilizados na indústria alimentícia. 1999. Dissertação (Mestrado) - Instituto de Pesquisas Energéticas e Nucleares, São Paulo.

5. ALISTE, A.J.; VIEIRA, F.F.; DEL MASTRO, N.L. Radiation effects on Agar, alginates and carrageenan to be used as food additives. Rad. Phys. Chem., v.57, n.3-6, p. 305-308, 2000.

6. ALISTE, A.J.; DEL MASTRO, N.L. Ascorbic acid as radiation protector on polysaccarides used in food industry. Coll Surf $A$, n.249, n. 1-3, p. 131133, 2004.

7. AYED N; YU H.L.; LACROIX M. Improvement of anthocyanin yield and shelf-life extension of grape pomace by gamma irradiation. Food Res. Int., v.32, n.8, p. 539-543, 1999. 
8. AZERO, E.G; ANDRADE, C.T. Efeito do Tempo de Pré-Tratamento da Alga Hypnea musciformis Sobre as Propriedades Mecânicas e Reológicas de Soluções de k-Carragenanas. Anais Assoc. Bras. Quím., v.46, n. 4, p. 250-255, 1997.

9. BARNES, S. Evolution of the health benefits of soy isoflavones. Proc. Soc. Exp. Biol. Med. V. 217, p. 386-392, 1998.

10.BAZAFKAN, S. Radiation protection on polysaccharide solutions and gels. Salford: 1996. Thesis (Ph.D.) - Department of Biological Sciences, University of Salford, United Kingdom.

11.BAZZOLI, D.L.; HILL, S.; DISILVESTRO, R.A. Soy protein antioxidant actions in active, young adult women. Nutr. Res., v. 22, n.7, p. 807-815, 2002.

12.BIRD, R.B.; STEWART, W.E.; LIGHTFOOT E.N. Transport phenomena. New York, John Willei \& Sons, 1965. p.780 apud CAMPOS, S.D.S. Curso: reologia e textura de alimentos. Campinas: Instituto de Tecnologia de Alimentos (ITAL), 1989. p.1-10.

13. BLOCK, G. Antioxidant vitamins and disease prevention. Food Technol., v. 48, n.1, p. 80-87, 1994.

14.BOISSON-VIDAL, C.; HAROUN, F.; ELLOUALI, M.; BLONDIN, C. Biological Activities of Polysaccharides From Marine Algae in Drugs Future, v.20, p. 1237-1249, 1995 apud DE RUITIER, G. A.; RUDOLPH, R Carrageenan biotechnology, Trends Food Sci. Technol., v. 8, n. 12, p. 389-401, 1997.

15.BORSA, J.; LACROIX, M.; OUATTARA, B.; CHIASSON, F. Radiosensitization: enhancing the radiation inactivation of foodborne bacteria. Radiat. Phys. Chem., v. 71, n. 1-2, p. 137-141, 2004. 
16. BRASIL. Ministério da Saúde. Portaria n. 30 de 25 de Setembro de 1989. Divisão Nacional de Vigilância Sanitária de Alimentos da Secretaria Nacional de Vigilância Sanitária. República Federativa do Brasil Diário Oficial [da], Brasília. DF 28 de Setembro de 1989. Seção 1.

17. BRASIL. Ministério da Saúde. Portaria n. 9 de 08 de Março 1985. Divisão Nacional de Vigilância Sanitária de Alimentos da Secretaria Nacional de Vigilância Sanitária. República Federativa do Brasil Diário Oficial [da], Brasilia. DF 13 de Março de 1985. Seção 1.

18. BRASIL. Ministério da Saúde. Resolução-RDC n. 21 de Janeiro de 2001. Agência Nacional de Vigilância Sanitária. República Federativa do Brasil Diário Oficial [da], Brasília. DF 29 de Janeiro de 2001. n. 20.

19. BROOKFIELD ENGENEERING LABORATORIES. More Solutions to Sticky Problems: A Guide to Getting More From your Brookfield Viscosimeter, Stoughton, [s.d.].

20. BUDAVARI, S.; O'NEIL, M.J.; SMITH, A.; HECKELMAN, P.E.; KINNEARY, J.F. The Merck Index, an encyclopedia of chemicals and drugs, 19. ed., p.1741, 1996.

21.CAMPOS, S.D.S. Curso: reologia e textura de alimentos, Campinas: Instituto de Tecnologia de Alimentos (ITAL), 1989. p.1-10.

22.CAO, G.H.; SOFIC, E.; PRIOR, R.L. Antioxidant and prooxidant behavior of flavonoids: Structure-activity relationships. Free Rad. Biol. Med., v. 22 , n. 5 , p. $749-760,1997$.

23. CHANG-CHE C.; FEN-PI C.;YUNG-CHIAN H.;WEA-LUNG L.; CHIN-PIN W.; ERL-SHYN K.; AN-CHUNG H.;CHAU-JONG W.; Inhibitory effects of Hibiscus sabdariffa $L$ extract on low-density lipoprotein oxidation and anti-hyperlipidemia in fructose-fed and cholesterol-fed rats. J Sci Food Agric., v.84, n.15, p. 1989-1996, 2004. 
24.DE KERF M.; MONDELAERS W.; LAHORTE P.; VERVAET C.; REMON J.P. Characterization and Disintegration Properties of Irradiated Starch. Int. J. Pharm., v. 221, n.1, p. 69-76, 2001.

25.DE RUITIER, G.A.; RUDOLPH, R. Carrageenan biotechnology, Trends Food Sci. Technol., v. 8, n. 12, p. 389-401, 1997.

26. DEL MASTRO, N.L. Noções básicas de química da radiação em sistemas biológicos. Publ. IPEN-CNEN/SP, v.1, n. 276, 17p. 1989.

27. DEL MASTRO, N.L. Alimentos Esterilizados para Uso em Hospitais e Rações Militares. Rev. Bras. Pesq. Desenvol. v. 2, n. 1, p. 1-4, 1999.

28.DIEHL, J. F. Safety of irradiated food. New York, N.Y.: Marcel Dekker, , 1990. p345.

29.DONNELLY J.K.; ROBINSON D.S. Invited Review Free Radicals. Foods Free Radic. Res., v.22, n. 1, p.147-176, 1995.

30.DUKE, J.A.; ATCHELY, A.A. Proximate analysis. In: Christie, B.R. (ed.), The handbook of plant science in agriculture. CRC Press, Inc., Boca Raton, FL. 1984.

31. EATON J.W. Is the Lens Canned? Free Rad. Biol. Med., v.11, n. 2, p. $207-$ 213, 1991.

32. FAN X.T, THAYER D.W. Quality of irradiated alfalfa sprouts. J. Food Protec., v. 64, n.10, p.1574-1578, 2001.

33.FAN, X.T. Formation of furan from carbohydrates and ascorbic acid following exposure to ionizing radiation and thermal processing. $J$. Agric. Food Chem., v. 53, n. 20, p. 7826-7831, 2005. 
34. FERREIRA, A.B.H. (Ed.). Novo Dicionário da Língua Portuguesa. 2. ed. Rio de Janeiro, RJ: Nova Fronteira, 1986. p 1227.

35.FRITZ, K.L.,; SEPPANEN C.M.; KURZER M.S.; CSALLANY A.S. The in vivo antioxidant activity of soybean isoflavones in human subjects, Nutrit. Res., v. 23, n. 4, pp. 479-487, 2003.

36. GETOFF, N.; PLATZER, I.; WINKELBAUER, C. Transients and cooperative action of beta-carotene, vitamin $E$ and $C$ in biological systems in vitro under irradiation, Rad. Phys. Chem., v. 55, n. 5-6, p. 699-704, 1999

37. GLICKSMAN, M. Seaweed extracts. Gum Technology in the food Industry. New York, N. Y.: Academic Press, 1969, p. 199-273.

38.GRADINARU G.; BILIADERIS C.G.; KALLITHRAKA S.; KEFALAS P.; GARCIA-VIGUERA C. Thermal stability of Hibiscus sabdariffa L. anthocyanins in solution and in solid state: effects of copigmentation and glass transition. Food Chem. v.83, p. 423-436 2003.

39. HAINES, J.; PATEL, P.D. Antibody-and lecitin-based assays for the rapid analisys of food grade gums and thickeners. Trends Food Sci. Technol., v. 8, n. 12, p. 395-400, 1997.

40.HALL, E.J. Radiobiology for the Radiologist. 4th ed..Ed. J.B. Lippincott Co., Philadelphia, 478p, 1994.

41. HARBORNE, J.B.; WILLIAMS, C. A. Advances in flavonoid research since 1992. Phytochem., v. 55, n. 6,2000

42. HAUG, A., Composition and properties of alginates, Norwegian Institute Seaweed Research, Trondheim, Norway, n. 30, 1964 
43.HAUG, A.; LARSEN, B., Quantitative determination of the uronic acid composition of alginates. Acta Chem. Scand., v. 16, p. 1908-1918, 1962

44. HAUG, A.; LARSEN, B.; SMIDSROD, O. A study of the constitution of alginic acid by partial acid hydrolysis. Acta Chem. Scand., v. 20, p. 183-190, 1966

45. HAUG, A.; LARSEN, B.; SMIDSROD, O. Studies on the sequence of the uronic acid residues in alginic acid. Acta Chem. Scand, v. 21, p. 691704, 1967.

46. HAUG, A.; MYKLESTAD, S.; LARSEN, B.; SMIDSROD, O. Correlation between chemical structure and physical properties of alginates. Acta Chem. Scand., v. 21, p. 768-778, 1967

47. HENDRICH, S. Bioavailability of isoflavones. J. Chrom. B, n. 777, p. $203-$ 210, 2002.

48. HERMANS, P. H., Gels. in Colloid Science, v. 2, p.483-651, ed. H. R. KRUYT, Elsevier, Amsterdam, 1949 .

49. HIENA N. Q., NAGASAWAB N., THAMA L. X., YOSHIID F., DANGC V. H.; MITOMOB H., MAKUUCHID K., KUMED T. Rad. Phys. Chem., v.1, n. 59, p. $97-101,2000$.

50. HOWARD, D.W. Viscosity Measurement-A Look at Viscosity, Food Technol., v. 7, p 82-84, 1991.

51. IAEA. INTERNATIONAL ATOMIC ENERGY AGENCY. Manual on radiation sterilization of medical and biological materiais, Vienna, 1973. (Technical Report Series, 149). 
52. INTERNATIONAL CONSULTATIVE GROUP ON FOOD IRRADIATION Fichas Descritivas do Grupo Consultivo Internacional Sobre Irradiação de Alimentos. Roma, 1990.

53. INTERNATIONAL CONSULTATIVE GROUP ON FOOD IRRADIATION. Training Manual on Operation of Food Irradiations Facilities. Documento, 14. Vienna, 1992.

54.JENKINS, D.J.A.; WOLEVER T.M.; LEEDS A.R.; GASSULL M.A.; DILAWARI J.B.; GOFF D.V.; METZ G.L.; ALBERTI G.M. Dietary fibers, fibre analogues and glucose tolerance: importance of viscosity, British Medical J., v. 6, p. 1392-1394, 1978 apud CAMPOS, S.D.S. Curso: reologia e textura de alimentos. Campinas: Instituto de Tecnologia de Alimentos (ITAL), 1989. p.1-10.

55.JO, J.Y.; DE MEJIA, E.G.; LILA, M.A. Effects of grape cell culture extracts on human topoisomerase catalytic activity and characterization of active fractions. J. Agric. Food Chem., v.53, n. 7, p. 2489-2498, 2005.

56. KAMAT, A. Microbiological aspect of radiation processing of foods. J. Food Sci. Technol.-Mysore, v. 42, n. 5; p. 371-383, 2005.

57. KAYACIER, A.; DOGAN, M. Rheological properties of some gums-salep mixed solutions.J. Food Eng., v. 72, p.261-265, 2005.

58. KHOPDE, S.M., PRIYADARSINI, K.I.; MOHAN, H. et al. Characterizing the antioxidant activity of amla (Phyllanthus emblica) extract. Current Sci., v. 81, n. 2, p. $185-190,2001$.

59.KNUTSEN, S.H., MYSLABODSKI, D.E., LARSEN, B, USOV, A. I. A Modified System of Nomenclature for Red Algal Galactans, Bot. Mar. v. 37, n. 2, p. 163-169, 1994. 
60. KOOIJ, J.V. Food preservation by irradiation. Int. At. En. Ag. Bull., v. 23, n. 3, p. 33-36, 1981.

61.KOROTCHENKO, K.A.; SHARPATYI, V.A. Radiation chemistry of polysaccharides: 3 . On the strange dose dependence of the buildup of some radiolysis products, High En. Chem., v.38, n.4, p. 231-235, 2004.

62.LE QUESTEL, J-Y.; CROS, S.; MACKIE, W.; PÉREZ, S. Computer Modelling of Sulfated Carbohydrates; Aplications to Carrageenans, J. Biol. Macromol., v.17, p. 161-174,1995

63. LOAHARANU, P. Food Irradiation in Developing Countries: A Pratical Alternative, Int. At. En. Ag. Bull., v. 1, p. 30-34, 1994.

64. MACDOWELL, R. H., New developments in the chemistry of alginates and their use in food., Chem. Ind., n.9, p. 391-395, 1975.

65. McHUGH, D.J.(Ed.). Production and Utilization of Products from Commercial Seaweeds. FAO Fish. Tech. Pap., n. 288, p. 189, 1987.

66. McHUGH, D.J.(Ed.). A guide to the seaweed industry. FAO Fish. Tech. Pap., n. 441, p. 118, 2003.

67. McNAUGHT, A.D. 'Nomenclature of Carbohydrates. Recommendations, Carbohyd. Res., n. 297, p.1-92, 1996.

68. MORAIS, C.; VALLE J.L.E.; PIZZINATTO A. Colódes de Algas Marinhas.III, Considerações Sobre o Agar-Agar, Colet. ITAL, v.19, n², p. 121-128; 1989.

69. MORAIS, C.; VALLE J.L.E.; PIZZINATTO A. Coloides de Algas Marinhas.II, Considerações Sobre as Carragenanas. Colet. ITAL, v.19, n. 1, p. 1224, 1989. 
70. OLIVEIRA FILHO, E.C.; QUÉJE, N. O gênero Laminaria (Phaeophyta) no Brasil, ocorrência e potencialidade econômica. São Paulo, SP: Inst. Pesq. Tecnológicas, 1978. (Pesquisa \& desenvolvimento, 1)

71. OSTERHOLM, M. T. Food Irradiation. J. Assoc Food Drug Officials, v. 68, n. 1, p.100-101, 2004.

72. PAPAS, A.M. Determinants of antioxidant status in humans. Lipids, v. 31, p.77-82,1996.

73. PERRY, L.M. Medicinal plants of east and Southeast Asia. MIT Press, Cambridge. 1980.

74.PETERSON, G.; BARNES, S. Genistein inhibition of the growth of human breast cancer cells: independence from estrogen receptors and the multi-drug resistance. Biochem. Biophys. Res. Commun., v. 179, p. 661-667, 1991.

75.REDDY, T.T.; TAMMISHETTI, S. Free radical degradation of guar gum, Polym. Degrad. Stabil., v. 86, n.3, p. 455-459, 2004.

76. RELLEVE L.; NAGASAWA N.; LUAN L.Q.; YAGI T.; ARANILLA C., ABAD L.; KUME T.; YOSHII F.; DELA ROSA A. Degradation of carrageenan by radiation. Polym. Degrad Stabil., v.87, n.3, p.403-410, 2005.

77.RIMBACH G.; WEINBERG P.D.; PASCUAL-TERESA S.; ALONSO M. G.; EWINS B.A.; TURNER R.; MINIHANE A.M.; BOTTING N.; FAIRLEY B.; MATSUGO S.; UCHIDA Y.; CASSIDY A. Sulfation of genistein alters its antioxidant properties and its effect on platelet aggregation and monocyte and endothelial function. Biochim. Bioph. Acta, v.1670, n.1, p. $229-237,2004$. 
78. SEERAM, N.P.; NAIR, M.G. Inhibition of lipid peroxidation and structure activity related studies of the dietary constituents anthocyanins, anthocyanidins and catechins. J. Agric. Food Chem., v.50, n.1, p.53085012, 2002.

79. SHIMONI, E. Stability and Shelf Life of Bioactive Compounds during Food Processing and Storage: Soy Isoflavones. J. Food Sci., v. 69, n. 6, p.160-6, 2004.

80. SILVA S. L. A.; FERREIRA G. A. L.; SILVA R. R. À Procura da Vitamina C, Quím. Nova na Escola, v.1, n. 2, p.31-32, 1995.

81. SPIEGEL, M. R. Estatística, 3.ed. São Paulo, S. P.: Makron Books, 1993.

82. THERKELSEN, G.H. Carrageenan in Industrial Gums: Polysaccharides and Their Derivatives (3rd edn), Whistler, R.L. and BeMiller, J.N., eds, p. 145-180, 1993 apud DE RUITIER, G. A.; RUDOLPH, R Carrageenan biotechnology, Trends Food Sci. Technol., v. 8, n. 12, p. 389-401, 1997.

83.TRIOLA, M. F., Introdução à Estatística. 7.ed. Rio de Janeiro, R.J.: LTC, 1999.

84. TROMMER, H.; NEUBER, R. H. H. The examination of polysaccharides as potential antioxidative compounds for topical administration using a lipid model system. Int. J. Pharmac., v. 298, n.1, p. 153-163, 2005.

85.VALLES-PAMIES, B.; BARCLAY, F. HILL, S.E.; et al. The effects of low weight additives on the viscosities of cassava starch. Carb. Polym., v. 34, n.1-2, p. 31-38, 1997. 
86.VAN WAZER, J.R.; LYONS, J.W.; KIM, K.Y.; COLWELL, R.E. Viscosity and flow measurement: A laboratory book of rheology, New York, Intersciences, 1963, p. 406 apud CAMPOS, S.D.S. Curso: reologia e textura de alimentos. Campinas: Instituto de Tecnologia de Alimentos (ITAL), 1989. p.1-10.

87. VIEBKE, C.; BORGSTRÖM, J.; PICULELL, L. Characterisation of Kappa and lota-carrageenan Coils and Helices by MALLS/GPC, Carb. Polym. v. 27, p. $145-154,1995$.

88. WASIKIEWICZ J.M.; YÓSHII F.; NAGASAWA N.; WACH R. A.; MITOMO $\mathrm{H}$.; Degradation of chitosan and sodium alginate by gamma radiation, sonochemical and ultraviolet methods. Rad. Phys. Chem., v.73, n.5, p. 287-295, 2005.

89.WATT, J.M.; BREYER-BRANDWIJK, M.G. The medicinal and poisonous plants of southern and eastern Africa. 2nd ed. E. \&S. Livingstone, Ltd., Edinburgh and London. 1962

90. WEISS, J.F.; LANDAUER, M.R. Radioprotection by antioxidants. Reactive Oxygen Species: From Radiation to Molecular Biology, v. 899, p. 44-60, 2000 .

91.WHO. Food irradiation, the position of the World Health Organization: Statement to the press, international conference on the acceptance, control of, and trade in irradiated food, 12-16 December 1988. Geneva, 1989.

92. WHO. Wholesomeness of food irradiated with doses above $10 \mathrm{kGy}$ : Report of a Joint FAO/IAEAMHO Study Group. Geneva, WHO, (Technical Report Series, 890), 1999. 
93. WITENBERG, B.; KLETTER, Y.; KALIR, H.H.; RAVIV, Z.; FENIG, E.; NAGLER, A.; HALPERIN, D.; FABIAN, I. Ascorbic acid inhibits apoptosis induced by X irradiation in HL60 myeloid leukemia cells. Rad. Res., v. 152, n. 5, p. 468-478, 1999.

94.WONG, P.Y.Y.; KITTS, D.D. Factors influencing ultraviolet and electron beam irradiation-induced free radical damage of ascorbic acid. Food Chem., v.74, n.1, p. 75-84, 2001.

95. YAMAGUCHI, H.; UCHIHORI, Y.; YASUDA, N.; et al. Estimation of yields of $\mathrm{OH}$ radicals in water irradiated by ionizing radiation. J. Rad. Res., v. 46, n.3, p.333-341, 2005.

96. YOSHII, F. Radiation processing of polysaccharide derivatives. In: JAERI Conference 2004-007, Proceedings of the FNCA 2003 Workshop on Application of Electron Accelerator, 2003, Kuala Lampur, Malaysia. p. 125-126. 